\title{
Uma abordagem visual para análise comparativa de redes biomoleculares com apoio de diagramas de Venn
}

Henry Heberle 

Data de Depósito:

Assinatura:

\title{
Uma abordagem visual para análise comparativa de redes biomoleculares com apoio de diagramas de Venn
}

\author{
Henry Heberle
}

Orientadora: Profa. Dra. Rosane Minghim

Dissertação apresentada ao Instituto de Ciências Matemáticas e de Computação - ICMC-USP, como parte dos requisitos para obtenção do título de Mestre em Ciências - Ciências de Computação e Matemática Computacional. VERSÃO REVISADA 
Ficha catalográfica elaborada pela Biblioteca Prof. Achille Bassi e Seção Técnica de Informática, ICMC/USP, com os dados fornecidos pelo(a) autor(a)

H445a $\begin{aligned} & \text { Heberle, Henry } \\ & \text { Uma abordagem visual para análise comparativa de } \\ & \text { redes biomoleculares com apoio de diagramas de Venn } \\ & \text { / Henry Heberle; orientadora Rosane Minghim. -- São } \\ & \text { Carlos, } 2014 \text {. } \\ & 98 \text { p. } \\ & \text { Dissertação (Mestrado - Programa de Pós-Graduação } \\ & \text { em Ciências de Computaça e Matemática } \\ & \text { Computacional) -- Instituto de Ciências Matemáticas } \\ & \text { e de Computação, Universidade de São Paulo, 2014. } \\ & \text { 1. Visualização de Informação. 2. Redes } \\ & \text { Biomoleculares. 3. Diagramas de Venn. 4. Comparação } \\ & \text { de redes. I. Minghim, Rosane, orient. II. Título. }\end{aligned}$




\section{Agradecimentos}

À minha mãe, Lúcia, por cuidar de mim e da minha família com muito amor e fé. Ao meu pai, Jerônimo, por acreditar em mim e me apoiar em todas as decisões.

À Rosane, Gabriela, Guilherme e Adriana pelas orientações, sugestões, participação na elaboração deste trabalho, amizade e motivação. À professora Rosemary Redfield pela grandiosa aula de genética oferecida à distância.

Aos meus amigos Paulo, Geandro, Michel, Pedro, Mônica, Rogério, Fábio e Murilo, por terem participado de minha vida e colaborado com este trabalho direta ou indiretamente.

Ao CNPq, pelo suporte financeiro, e ao ICMC-USP, pelo suporte acadêmico. 

Essentially, all models are wrong, but some are useful.

George Edward Pelham Box 



\section{Resumo}

Sistemas biológicos podem ser representados por redes que armazenam não apenas informações de conectividade, mas também informações de características de seus nós. No contexto biomolecular, esses nós podem representar proteínas, metabólitos, entre outros tipos de moléculas. Cada molécula possui características anotadas e armazenadas em bases de dados como o Gene Ontology. A comparação visual dessas redes depende de ferramentas que permitam o usuário identificar diferenças e semelhanças entre as anotações feitas sobre as moléculas (atributos) e também sobre as interações conhecidas (conexões). Neste trabalho de mestrado, buscou-se desenvolver técnicas que facilitem a comparação desses atributos sobre as moléculas, tentando manter no processo a visualização das redes em que essas moléculas estão inseridas. Como resultado, obteve-se a ferramenta VisPipeline-MultiNetwork, que permite comparar até seis redes, utilizando operações de conjuntos sobre as redes e sobre seus atributos. Dessa forma, diferentemente da maioria das ferramentas conhecidas para a visualização de redes biológicas, o VisPipeline-MultiNetwork permite a criação de redes cujos atributos são derivados das redes originais por meio de operações de união, intersecção e valores exclusivos. A comparação visual das redes é feita pela visualização do resultado dessas operações de conjuntos sobre as redes, por meio de um método de comparação lado-a-lado. Já a comparação dos atributos armazenados nos nós das redes é feita por meio de diagramas de Venn. Para auxiliar este tipo de comparação, a técnica InteractiVenn foi desenvolvida, em que o usuário pode interagir com um diagrama de Venn efetuando operações de união entre conjuntos. Essas operações de união aplicadas sobre os conjuntos são também aplicadas sobre as respectivas formas no diagrama. Esta característica da técnica a diferencia das outras ferramentas de criação de diagramas de Venn. Integrando essas funcionalidades, o usuário é capaz de comparar redes sob diversas perspectivas. Para exemplificar a utilização do VisPipeline-MultiNetwork, dois casos no contexto biomolecular foram estudados. Adicionalmente, uma ferramenta web para a comparação de listas de cadeias de caracteres por meio de diagramas de Venn foi desenvolvida. Ela também implementa a técnica InteractiVenn e foi denominada InteractiVenn website.

Palavras-chaves: visualização de informação, redes biomoleculares, comparação de redes, diagramas de Venn. 



\section{Abstract}

Biological systems can be represented by networks that store not only connectivity information, but also node feature information. In the context of molecular biology, these nodes may represent proteins, metabolites, and other types of molecules. Each molecule has features annotated and stored in databases such as Gene Ontology. A visual comparison of networks requires tools that allow the user to identify differences and similarities between nodes' attributes as well as known interactions between nodes (connections). In this dissertation, we sought to develop a technique that would facilitate the comparison of these biological networks, striving to maintain in the process the visualization of the network connectivities. As a result, we have developed the VisPipeline-MultiNetwork tool, which allows comparison of up to six networks, using sets of operations on networks and on their attributes. Unlike most known tools for visualizing biological networks, VisPipeline-MultiNetwork allows the creation of networks whose attributes are derived from the original networks through operations of union, intersection and unique values. A visual comparison of the networks is achieved by visualizing the outcome of such joint operations through a all-in-one comparison method. The comparison of nodes attributes is performed using Venn diagrams. To assist this type of comparison, the InteractiVenn technique was developed, in which the user can interact with a Venn diagram, performing union operations between sets and their corresponding diagrams. This diagram union feature differs from other tools available for creating Venn diagrams. With these tools, users manage to compare networks from different perspectives. To exemplify the use of VisPipeline-MultiNetwork, two case studies were carried out in the biomolecular context. Additionally, a web tool for comparing lists of strings by means of Venn diagrams was made available. It also implements the InteractiVenn technique and its site has been named InteractiVenn.

Key-words: information visualization, biomolecular networks, networks comparison, Venn diagrams. 



\section{Lista de ilustrações}

Figura 1 - Via metabólica de coloração de pulgões. . . . . . . . . . . . . . . . . 24

Figura 2 - Representação visual de uma via metabólica da espécie Mus musculus . 25

Figura 3 - Processo de ativação e início da transcrição . . . . . . . . . . . . 27

Figura 4 - Fotografias de duas variações da flor Morning glory ocorridas por regulação genética . . . . . . . . . . . . . . . . . . . . 27 27

Figura 5 - Regulação da catálise por proteína ativadora e por metabólito inibidor 28

Figura 6 - Diagrama representando dois conjuntos, de números divisíveis por três e por cinco . . . . . . . . . . . . . . . . . . . 30

Figura 7 - Exemplo de diagrama de Euler representando argumentos lógicos . . . 31

Figura 8 - Diagrama de Venn representando argumentos lógicos . . . . . . . . . 31

Figura 9 - Exemplos de diagramas para dois, três, quatro, cinco e seis conjuntos . 33

Figura 10 - Exemplos de diagramas de Venn para seis e sete conjuntos . . . . . . . 34

Figura 11 - Exemplo de diagrama Edwards-Venn para sete conjuntos . . . . . . . . 34

Figura 12 - Exemplo de Nested Venn Diagram, para até seis conjuntos . . . . . . . 35

Figura 13 - Exemplo de digrama de Venn com formatos proporcionais à cardinalidade dos conjuntos . . . . . . . . . . . . . . . . . 36

Figura 14 - Diagrama representando um grafo $G \ldots \ldots$. . . . . . . . . 37

Figura 15 - Exemplo de desenho de rede pela ferramenta Biofabric . . . . . . . . . 38

Figura 16 - Comparação de redes lado a lado . . . . . . . . . . . . . . . . . . . . 39

Figura 17 - Comparação de duas pequenas redes . . . . . . . . . . . . . . . 40

Figura 18 - Comparação de três pequenas redes . . . . . . . . . . . . . . . . . 41

Figura 19 - Interface gráfica do plugin Venn-cytoscape-plugin da ferramenta Cytoscape 42

Figura 20 - Diagrama de Venn de comparação de três métodos fictícios de identificação de proteínas. . . . . . . . . . . . . . . . . . . . . . . . . . . . . . 44

Figura 21 - Diagrama de Edwards-Venn exibindo a distribuição de genes compartilhados entre seis espécies. . . . . . . . . . . . . . . . . 45

Figura 22 - Árvore filogenética distribuindo espécies pelas similaridades e também identificando seus períodos de surgimento. . . . . . . . . . . . . . . 46

Figura 23 - Comparação entre duas espécies num diagrama de seis espécies. . . . . 47

Figura 24 - InteractiVenn Website . . . . . . . . . . . . . . . . . 48

Figura 25 - Representação do conjunto de dados Musa acuminata pelo InteractiVenn website . . . . . . . . . . . . . . . . . . 4 49

Figura 26 - Representação de árvore filogenética considerando seis espécies . . . . . 50

Figura 27 - Diagrama de comparação entre monocotiledôneas e Arabidopsis thaliana 51

Figura 28 - Modelagem em rede das vias completa e incompleta de pigmentação de pulgões. . . . . . . . . . . . . . . . . . . . . 53

Figura 29 - Comparação de dois tipos de geração de diagramas de Venn por meio de atributos de redes . . . . . . . . . . . . . . . . 54 
Figura 30 - Pipeline de visualização do VisPipeline-Multinetwork . . . . . . . . . . 56

Figura 31 - Janela de entrada das redes no VisPipeline-MultiNetwork . . . . . . . . 57

Figura 32 - Janela do componente MultiNetwork Filter . . . . . . . . . . . . . 57

Figura 33 - Janela do componente MultiNetwork Operations . . . . . . . . . . . 58

Figura 34 - Janela do componente Attributes Projection Layout . . . . . . . . . . . 58

Figura 35 - Janela de interação com a rede final . . . . . . . . . . . . . . . . . . . 59

Figura 36 - Exemplo de projeção de rede baseada um único atributo. . . . . . . . . 61

Figura 37 - Exemplo de representação de multivalores em um vértice . . . . . . . . 62

Figura 38 - Exemplo de destaque de vértices por meio de polígonos . . . . . . . . . 64

Figura 39 - Exemplo de projeção de rede baseada um único atributo com destaque de polígonos . . . . . . . . . . . . . . . . . . . . . 64

Figura 40 - Janela de exibição e interação de diagramas de Venn do VisPipelineMultiNetwork. . . . . . . . . . . . . . . . 66

Figura 41 - Projeção baseada em processos biológicos e identificação de cada proteína em cinco condições diferentes. . . . . . . . . . . . . . . . . . 72

Figura 42 - Diagrama representando as intersecções entre as cinco condições. . . . 73

Figura 43 - Diagramas representando a comparação entre condições duas a duas. 74

Figura 44 - Diagrama de Venn comparando os processos biológicos encontrados nas cinco condições. . . . . . . . . . . . . . . . . . . . . . 75

Figura 45 - Diagrama de Venn comparando os processos biológicos encontrados nas três condições. . . . . . . . . . . . . . . . . . . . . . 81

Figura 47 - Projeção baseada nos atributos "expressão" e selected-cellular-component. 83

Figura 49 - Diagramas baseados em valores de expressão (up, down e noinfo). . . . 85

Figura 50 - Projeção baseada nos atributos Networks e top-enriched-bp. . . . . . . 86

Figura 51 - Projeção baseada nos atributos "expressão" e selected-cellular-component. 87

Figura 52 - Projeção baseada no atributo "expressão". . . . . . . . . . . . . . . . . 87

Figura 53 - Desenho de grafo baseado em forças. . . . . . . . . . . . . . . . . . 88 


\section{Lista de abreviaturas e siglas}

$B I N D$ Biomolecular Interaction Network Database

Binding DB Binding DataBase

BioGRID General Repository for Interaction Datasets

$B Y \quad$ Atribuição

$B Y-N C$ Atribuição-NãoComercial

$B Y-N C-S A$ Atribuição-NãoComercial-CompartilhaIgual

$C C$ Creative Commons

DIP Database of Interacting Proteins

DNA Deoxyribonucleic Acid

dpi dias pós-infecção

Embrapa Empresa Brasileira de Pesquisa Agropecuária

GO Gene Ontology

HEK Human Embryonic Kidney

ICMC Instituto de Ciências Matemáticas e de Computação

LNBio Laboratório Nacional de Biociências

MINT Molecular INTeraction database

MIPS Munich Information Center for Protein Sequences

$m R N A$ RNA mensageiro

$p R B$ proteína Retinoblastoma

$R N A$ Ácido Ribonucleico

$S A C M V$ South African cassava mosaic virus

STRING Search Tool for the Retrieval of Interacting Genes/proteins

UNICAMP Universidade de Campinas

UniProt Universal Protein Resource

USP Universidade de São Paulo

VICG Visualização, Imagens e Computação Gráfica 



\section{Sumário}

INTRODUÇÃo $\ldots \ldots \ldots \ldots \ldots \ldots \ldots$

FUNDAMENTOS E REVISÃO BIBLIOGRÁFICA . . . . . . . 21

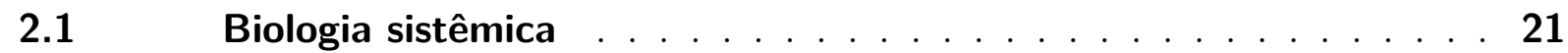

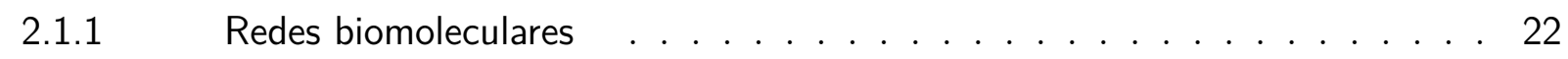

2.1.1. Regulação da transcrição . . . . . . . . . . . . . . 26

2.1.1.2 Regulação da catálise . . . . . . . . . . . . . . . . . . . 28

$2.2 \quad$ Conjuntos . . . . . . . . . . . . . . . . . 28

$2.2 .1 \quad$ Teoria dos conjuntos . . . . . . . . . . . . . . . . . 29

2.2.2 Técnicas de visualização de conjuntos . . . . . . . . . . . . . . . 30

$2.3 \quad$ Grafos e redes . . . . . . . . . . . . . . . . . 36

2.3.1 Definição de grafos . . . . . . . . . . . . . . . . 37

2.3.2 Visualização de redes . . . . . . . . . . . . . . . . . . 37

2.3.3 Técnicas visuais de análise de relações entre redes . . . . . . . . . . . . 39

2.4 Relações entre conjuntos e redes . . . . . . . . . . . . . 41

3 VISUALIZAÇÃO COMPARATIVA DE REDES BIOMOLECULARES 43

3.1 Diagramas de Venn interativos . . . . . . . . . . 43

3.1.1 InteractiVenn website . . . . . . . . . . . . . . . 45

$3.2 \quad$ Análise comparativa de redes biomoleculares . . . . . . . . . 51

3.2.1 VisPipeline-MultiNetwork e o pipeline de visualização . . . . . . . . . . 55

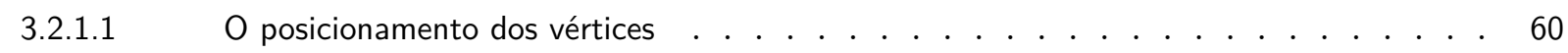

3.2.1.2 Representação visual de múltiplos valores e destaque de regiões . . . . . . . . . . 62

3.2.1.3 Integrando o InteractiVenn ao VisPipeline-MultiNetwork . . . . . . . . . . . 65

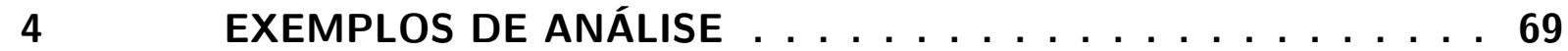

4.1 Exemplo 1: Avaliação do proteoma de célula HEK em diferentes tempos de corrida no espectrômetro de massa . . . . . . . . . 70

4.1.1 Motivação, definição do problema e design experimental . . . . . . . . . 70

4.1.2 Análise visual das cinco condições: 12, 30, 40, 120 e 173 minutos . . . . . 71

4.2 Exemplo 2: Alterações no transcritoma de Arabidopsis thaliana em resposta à infecção pelo vírus SACMV . . . . . . . . . . 77

4.2.1 Motivação, definição do problema e design experimental . . . . . . . . 77

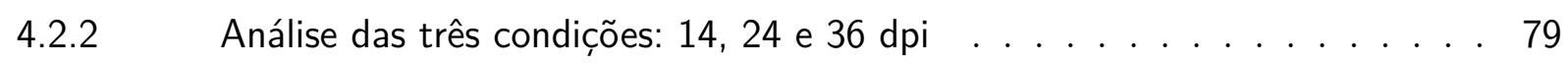

$5 \quad$ CONCLUSÕES $\ldots \ldots \ldots \ldots \ldots$

Referências . . . . . . . . . . . . . . 93 



\section{Introdução}

Muitas são as áreas que necessitam de comparações entre conjuntos para a identificação de suas semelhanças e diferenças. Em Ciências Biológicas pode-se citar a Ecologia, a Citologia e a Biologia Molecular - que abrange outras áreas da biologia e da química, como a genética e a bioquímica.

Com o progresso da Bioinformática, muitas espécies já tiveram seus genomas digitalizados. Há avanços também na obtenção de fotografias da dupla hélice do DNA (Ácido Desoxirribonucleico) (GENTILE et al., 2012), o que aumenta o número de informações disponíveis e aprimora a precisão de modelos tridimensionais. O custo do sequenciamento do genoma humano, por exemplo, caiu de U\$100 milhões para menos de U\$ 10 mil do que há pouco mais de uma década. No geral, sequenciar DNAs se tornou uma tarefa entre 10 mil e 20 mil vezes mais barata, devido à produção em massa de sequenciadores de segunda geração, e essa queda nos preços supera a estimativa da Lei de Moore na informática (PIVETTA, 2013).

Além do baixo custo, o tempo também foi reduzido. Para o primeiro genoma humano ser sequenciado, até o fim de seu projeto, se passaram 13 anos. Atualmente, é possível determinar a sequência genética de um ser humano em apenas alguns dias (PIVETTA, 2013). Se, por um lado, o sequenciamento barato tem resultado em diversas bases de dados genéticos (muitas de acesso livre), por outro, a complexidade de análise dos mesmos tem aumentado.

A análise desses dados não consiste simplesmente em entender suas sequências de bases nitrogenadas, mas também o funcionamento do organismo, a função de cada gene, a interação entre suas moléculas, entre outros fatores biológicos.

Tudo isso forma o que se chama de sistemas biológicos. Por motivo do grande número de dados resultantes de experimentos diversos, muitos pesquisadores têm estudado alternativas para que todos os dados possam ser integrados para apoiar novas descobertas. Algumas bases de dados conhecidas já foram criadas com essa intenção, as quais fazem uso de ontologias sobre o tema. Em geral, as bases armazenam muitas informações resultantes de pesquisas do mundo inteiro, como estruturas e sequências de proteínas, sequências de DNA, vias metabólicas, entre muitas outras.

Como exemplos de bases de interação, pode-se citar:

a) BIND: Biomolecular Interaction Network Database (BADER; BETEL; HOGUE, 2003);

b) STRING: Search Tool for the Retrieval of Interacting Genes/proteins (FRANCESCHINI et al., 2013);

c) DIP: Database of Interacting Proteins (XENARIOS et al., 2000); 
d) BioGRID: General Repository for Interaction Datasets (STARK et al., 2006);

e) MINT: Molecular INTeraction database (CHATR-ARYAMONTRI et al., 2007);

Já como exemplos de bases de anotação, tem-se:

a) BindingDB: Binding Database (LIU et al., 2007);

b) UniProt: Universal Protein Resource (JAIN et al., 2009);

c) MIPS: Munich Information Center for Protein Sequences (MEWES, 2002);

d) GO: Gene Ontology (ASHBURNER et al., 2000).

Nesse contexto, o uso de ferramentas de visualização de informação se faz necessário para auxiliar a extração de conhecimento desses grandes conjuntos de dados. Por meio dessas ferramentas, o analista busca por respostas formuladas com base na sua experiência, mas também realiza tarefas exploratórias buscando por informações novas.

Parte dos dados disponibilizados são de redes em nível biomolecular, como de interação entre proteínas, de caminhos metabólicos e de redes de regulação genética; outros dados já são de nível mais alto, como de cadeia alimentar, de árvores filogenéticas, etc.

Uma das importantes tarefas da análise em biologia molecular é o entendimento dos conjuntos de moléculas, da maneira com que interagem, dos resultados dessas interações e da localização de tais atividades. Se, por exemplo, uma criança desenvolve Retinoblastoma, sabe-se que se trata de um efeito de uma mutação na proteína retinoblastoma (pRB) . Essa proteína tem fator de prevenção, não permitindo que partes danificadas do DNA sejam replicadas (HARRINGTON et al., 1998).

Esse tipo de informação requer, para a sua descoberta, análise das interações das proteínas com elas mesmas e com outras moléculas que participam da via em questão, que impedem a replicação de DNA danificado e, consequentemente, previnem o crescimento desregulado de células com funções inativas ou inapropriadas ao ser vivo relacionado. Efetuar apenas conferência da expressão da pRB numa célula de um tecido com o câncer em comparação a uma célula de um tecido sem retinoblastoma não é suficiente para fazer tais afirmações.

Ferramentas de visualização de informação podem ajudar neste processo e processos similares no contexto biomolecular. Nele pode existir mais de uma rede de interação entre moléculas. Essa diferença pode ser induzida, por exemplo, condicionando células de um mesmo tecido a ambientes diferentes; pode ser também analisada em diferentes estágios da vida das células. Cada uma dessas condições deriva uma rede de interações diferente.

A diferença desses tipos de redes não está somente na existência de determinadas conexões ou nós - certas proteínas podem ou não existir em determinado estágio de uma célula ou interagir com outras proteínas. Há também mudanças de processos biológicos, 
de expressão, de localização (partições celulares), entre várias outras características que são atribuídas aos nós ou conexões.

Proteínas desempenham um papel fundamental em muitos processos biológicos, como o metabolismo, o desenvolvimento, a locomoção e reprodução (BRASCH; LINSEN; FUELLEN, 2007). Por isso a análise de suas interações tem grande importância na área, inclusive na explicação da evolução das espécies e origem da espécie humana.

Há na literatura diversas ferramentas de visualização de conjuntos e redes gerais e ferramentas que utilizam mais de uma técnica de visualização para aumentar seu poder de expressão. Algumas delas são feitas para a análise de dados biológicos em particular.

$\mathrm{Na}$ genética, são necessárias ferramentas visuais tanto para a análise de redes, conjuntos e sequências isolados, bem como para a comparação entre eles. É preciso, por exemplo, comparar o conjunto de genes entre duas espécies para identificar semelhanças e diferenças.

Por motivo da alta complexidade e grande volume de dados, a visualização de redes por desenho de vértices e arestas é usualmente prejudicada, já que resulta em excesso de cruzamentos de linhas, formas e contornos, e não se consegue identificar as relações entre redes com facilidade. Interações como a coordenação entre as redes, a análise multi-escala, o filtro por nós de interesse, a mudança de cores e escala são necessárias para este tipo de análise (SAMATOVA et al., 2008). Três métodos básicos de comparação são: alinhamento de redes (lado a lado), integração de redes (todas em uma) e busca em redes (filtro) (SHARAN; IDEKER, 2006). Estes podem ser utilizados de acordo com os dados e as expectativas, juntamente de outras técnicas, para auxiliar a comparação sem ser muito prejudicado pelo pequeno campo de visão ou excesso de cruzamento de arestas.

Além dos conjuntos de dados conterem informações sobre as interações entre as unidades biológicas, é possível que o analista queira relacionar também às visões, conteúdo de conjuntos associados. Se cinco redes foram unidas por uma operação de união sobre seus vértices, arestas e atributos relacionados, a rede resultante pode ser visualizada e, em paralelo, as redes ou valores das redes podem ser representadas por outra técnica, afim de relacionar as informações.

Neste trabalho foram estudadas formas de visualização desses tipos de relações entre redes, buscando alternativas para a comparação de redes, em nível de vértices e arestas, e também em nível de conjunto de valores de seus atributos. Para isso, foi proposta a utilização de operações de conjuntos sobre redes, seguidas de técnicas de visualização. Para o desenho dos nós e conexões, foi proposta a utilização de projeção multidimensional e o algoritmo baseado em forças; para a análise de relações entre valores das redes, foi empregada e aprimorada a técnica de diagramas de Venn. Todo o desenvolvimento deste trabalho contou com o apoio e colaboração de pesquisadores do Laboratório Nacional de 
Biociências (LNBio), Dra. Gabriela Vaz Meirelles e Dra. Adriana Paes Leme, para que as funcionalidades implementadas fossem relevantes à pesquisa biológica. Além do LNBio, este trabalho também contou com colaboradores na Universidade de Campinas (UNICAMP), professor Dr. Guilherme Pimentel Telles, e da Embrapa de Campinas (Dr. Felipe Rodrigues da Silva). O desenvolvimento das técnicas se deu no laboratório de Visualização, Imagens e Computação Gráfica (VICG) do Instituto de Ciências Matemáticas e Computação (ICMC) da Universidade de São Paulo (USP).

As técnicas implementadas neste trabalho de mestrado são capazes de auxiliar a comparação de redes biomoleculares. O trabalho permitiu a identificação da complexidade desse tipo de dado e da necessidade de ferramentas mais específicas e apropriadas, como é o caso da utilização de atributos multivalorados, em contraste ao que oferecem as ferramentas mais populares para visualização de redes.

A pesquisa permitiu a construção do software VisPipeline-MultiNetwork, uma ferramenta de exploração e comparação de redes, que possibilita a análise de redes cujos nós possuem atributos multivalorados (mais de um valor para um mesmo nó) ou são multiclasse (cada nó pode pertencer a múltiplas classes). Além disso, a ferramenta permite que sejam feitas operações de intersecção, união e identificação de vértices exclusivos entre redes, refletindo-as não apenas nos nós e conexões, mas também nos seus atributos. A ferramenta tem como funcionalidade principal a utilização de diagramas de Venn para apoiar a comparação e análise das redes.

Outro produto deste trabalho de mestrado é o InteractiVenn website ( $<$ www. interactivenn.net $>$ ), que permite a exploração e comparação de listas de cadeias de caracteres. Essas cadeias de caracteres podem representar elementos de qualquer entidade, como genes e proteínas. No website, o usuário pode aplicar operações de união nos conjuntos, sendo que essa operação é refletida aos respectivos formatos que formam o diagrama de Venn.

Embora o objetivo principal seja a análise de conjuntos de dados biológicos, as ferramentas desenvolvidas podem apoiar a análise de redes de outras naturezas.

No Capítulo 2, são apresentados conceitos básicos sobre o que representam as redes biológicas, como elas são formadas e como elas podem ser modeladas. Também é descrita a área de biologia de sistemas, assim como técnicas de análise de conjuntos gerais e de redes. No Capítulo 3, são descritas as soluções e desenvolvimento do VisPipeline-MultiNetwork. No Capítulo 4, são apresentados exemplos de análises biológicas utilizando a ferramenta, demonstrando como as soluções apresentadas funcionaram para esses casos. 


\section{Fundamentos e Revisão Bibliográfica}

\subsection{Biologia sistêmica}

Atualmente o número de bases de dados de diversos tipos de moléculas, de diversas espécies de seres vivos, entre outras entidades, é muito grande. Além disso, essas moléculas interagem e desempenham funções nos seres vivos de maneira não trivial. Analisar cada parte, cada conjunto de informações provenientes de cada pesquisa traz diversos resultados, porém, pode-se conseguir ainda mais com a integração delas.

É nesse cenário que surgiu o termo Systems Biology, comumente traduzido diretamente para "Biologia de Sistemas". Uma outra tradução defendida para a área é "Biologia Sistêmica", dado que o adjetivo que o acompanha é mais completo semanticamente. Tal área se refere ao estudo dos sistemas como um todo, analisando os genes, as proteínas, os metabólitos, suas interações, regulações, produtos, funções, entre outras características.

Devido à grande dimensão de cada uma das áreas de pesquisa relacionadas à Biologia Sistêmica, outros termos surgiram. O termo genômica se refere aos genomas, formados por dados completos do DNA e seus genes codificados; transcriptômica se refere aos transcriptomas, que envolvem regulação genética e níveis de expressão dos genes; proteômica se refere aos proteomas, que envolvem conjuntos de proteínas produzidas em cada sistema (Virginia Commonwealth University, 2009).

Essas três áreas e muitas outras denominadas "ômicas" interagem para estudar redes de cada espécie, conhecidas como interactomas - principais objetos de estudo da Biologia Sistêmica, já que representa o sistema biomolecular como um todo. Juntas e com o apoio de ferramentas computacionais para a análise de dados em larga escala, pretende-se entender os organismos, como eles funcionam e como é possível modificar esses sistemas biológicos a fim de melhorá-los ou corrigir algum problema que compromete a saúde do organismo relacionado (Virginia Commonwealth University, 2009).

Entre os problemas desses sistemas, pode-se citar as doenças para as quais é difícil encontrar cura com análises de pequenas partes do sistema, sem considerar o que está ao redor dessas partes. Ampliando o domínio da análise, pode-se chegar a resultados que não se chegaria analisando o problema apenas por um tipo de visão; isto é, visão da transcriptômica, genômica, entre outras. A integração dessas áreas permitem tratamentos personalizados a partir da análise global do organismo, do seu próprio sistema biológico que constitui a vida (Virginia Commonwealth University, 2009).

Essa ideia de personalização parte do princípio de que os seres de uma espécie possuem sistemas biológicos semelhantes e que as pequenas diferenças podem tornar o tratamento de uma doença completamente diferente entre um indivíduo e outro. Mesmo um câncer de pele em dois pacientes, por mais parecidos que os cânceres sejam ao considerar 
a localização, o comportamento e a aparência, podem ser completamente diferentes com relação à sua origem no nível biomolecular.

De modo geral, as redes biomoleculares nos interactomas são de quatro tipos:

a) redes de interação entre proteínas: representam as interações entre proteínas e seus processos biológicos correspondentes (PELLEGRINI; HAYNOR; JOHNSON, 2004);

b) redes metabólicas: representam o metabolismo em forma de operações químicas que ocorrem nas células (JEONG et al., 2000);

c) redes regulatórias: representam os fatores reguladores da expressão dos genes, relacionados à regulação do processo de transcrição (LEE et al., 2002);

d) redes de sinalização: representam as interações entre moléculas que possibilitam a transmissão de sinais externos a célula à regiões internas da mesma (KHOLODENKO; HANCOCK; KOLCH, 2010).

Um sistema biológico pode ser representado por uma rede, permitindo a utilização de variadas técnicas e teorias já estabelecidas. Exemplos são a identificação de motivos (subestruturas da rede que estão relacionadas à funções biológicas) (MILO et al., 2002), o cálculo da distribuição das conectividades (BARABÁSI; OLTVAI, 2004), a identificação de grupos de moléculas, a predição de interações (WILES et al., 2010) e o cálculo de coeficientes de agrupamento (WATTS; STROGATZ, 1998). Essas técnicas ajudam a ter uma visão do funcionamento do sistema e dão pistas sobre fatos a serem descobertos e comprovados biologicamente com experimentos posteriores.

\subsubsection{Redes biomoleculares ${ }^{1}$}

Redes biomoleculares são redes biológicas que representam a interação entre moléculas. Exemplos são as redes de regulação genética, as redes metabólicas e as redes de interações entre proteínas, ou qualquer outra rede que se possa construir a partir de dados e evidências da biologia, não necessariamente estruturas gerais, mas específicas de uma determinada análise.

Essas redes são representações do que acontece nos seres vivos no nível molecular. Assim, elas mostram como um gene é traduzido em uma proteína, o que faz a quantidade dessa proteína ser grande ou pequena em uma célula, que proteína transforma uma substância em outra, que substância ativa uma enzima, que metabólitos ou proteínas têm o maior ou menor número de funções, entre diversas outras informações que podem ser expressas em forma de redes.

\footnotetext{
${ }^{1}$ As informações desta seção e subseções foram extraídas do curso Useful Genetics, oferecido pela professora doutora Rosemary Redfield da University of British Columbia. O curso foi oferecido por meio da ferramenta de aprendizado eletrônico Coursera (https://class.coursera.org) (REDFIELD, 2013).
} 
Apesar dos variados tipos, essas redes têm estruturas muito parecidas. Os nós das redes costumam representar as moléculas e as conexões das redes representam as interações que acontecem entre elas.

As moléculas mais comuns nesses tipos de redes são as proteínas e os genes, representando o que interage com o que. Subconjuntos dessas interações, por exemplo, algumas proteínas e interações formando uma via metabólica, estão relacionados a funções metabólicas, a características fenotípicas dos seres, dentre outras relações resultantes das interações.

Um exemplo do que significa um componente da rede ou parte da rede estar ativado ou inibido pode ser visto na Figura 1. Em 1(a), via completa e funcional, o pigmento 1 do início da vida do pulgão é convertido em um pigmento 2 , rosado, pela enzima $A$. Posteriormente, esse pigmento é convertido em um verde pela enzima B. Há estudos que definem de onde surgiu tal gene que o deixa rosa, característica ruim para a espécie na seleção natural (MORAN; JARVIK, 2010). Sua característica "correta" final é a cor verde, pois se camufla nas folhas da maioria dos vegetais.

Esse processo é chamado de via metabólica, e essa em particular, é responsável pela pigmentação do inseto. Pequenas mudanças nessa via podem gerar pulgões com cores ou tonalidades diferentes.

Quando há ausência ou baixa concentração de uma enzima em um meio, diz-se que o nível de expressão dela é baixo, que a enzima não está sendo expressa, ou que ela é down-regulada. Suponha que o caso exemplificado seja de um pulgão com alelos ${ }^{2} A A$ (dois alelos dominantes e sem mutação que impeça o funcionamento esperado do gene) e $B B$ (AA/BB). Então, esse pulgão tem quantidade suficiente de enzimas A e B funcionais para a conversão dos pigmentos. Agora, suponha que o pulgão seja $A A / B b$, pois um alelo (representado por $b$ ) sofreu mutação durante a meiose e a enzima produzida por esse alelo perdeu sua função. Este pulgão tenderá a ser não tão verde ou com leve tonalidade na cor rosa, pois produz aproximadamente a metade do esperado das enzimas B. Suponha, agora, um pulgão $a a / B B$, ou seja, com os dois alelos "A" mutados e que geram enzimas do tipo "A" sem função. Este é o exemplo representado em 1(b). Nele, como não há nenhuma produção de enzimas $A$ funcionais, os pulgões acabam ficando transparentes (pigmento 1 ) por toda a vida.

Com a ausência da enzima A, o problema da transparência acontece mesmo com a

\footnotetext{
${ }^{2}$ Alelos são formas em que um gene aparece em uma sequência de DNA. Por exemplo, os alelos B e b podem representar o gene ligado a presença e ausência de chifres em um boi. B pode indicar a presença e b a ausência. A letra maiúscula é associada a forma dominante do gene, enquanto a minúscula está ligada a recessividade. Se a presença de chifres acontece devido à dominância do gene, então, bois que possuem em uma hélice de DNA o alelo B e na outra um alelo b, ele ainda possuirá chifres. O mesmo para B e B. Já quando ambas as hélices de DNA do boi possuem alelos b (recessivo), então, ele não terá chifres. Usualmente as letras da dupla hélice de DNA são escritas juntas. Para o gene em questão, então, há quatro possibilidade de combinações de alelos: bb, bB, Bb e BB.
} 
Figura 1 - Via metabólica de conversão de pigmentos de uma espécie de pulgões. Em (a), via completa funcional, o pigmento do início da vida do pulgão é convertido em um pigmento rosado pela enzima $A$ e posteriormente convertido em um pigmento verde pela enzima $B$. A ausência da enzima $A$ implica na não produção do pigmento rosa e consequentemente a enzima $B$ não terá o que converter em pigmento verde. O processo é representado em (b), e o resultado são pulgões com a mesma cor inicial.

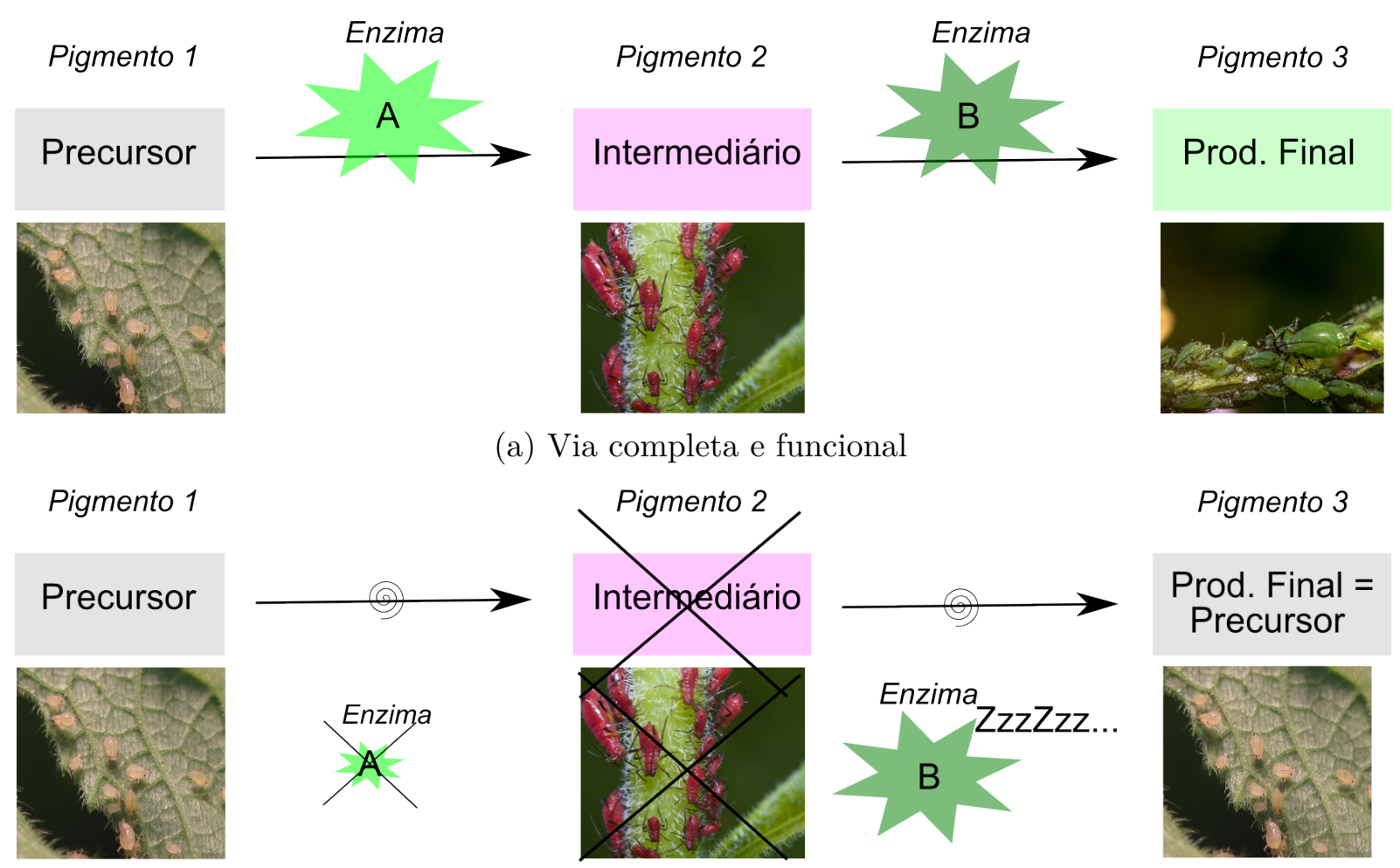

(b) Via com enzima faltando

Fonte: Fotografias dos pulgões transparentes, rosas e verdes disponibilizadas respectivamente por: Penn State $^{a}$, Steve Begin ${ }^{b}$, Lennart Tange ${ }^{c}$.

${ }^{a}$ Disponível em http://www.flickr.com/photos/pennstatelive/4950462105/, sob licença CC (Creative Commons) BY-NC (Atribuição-NãoComercial) 2.0 Genérica.

${ }^{b}$ Disponível em http://www.flickr.com/photos/stephenbegin/3694083750/, sob licença CC BY-NC-SA (Atribuição-NãoComercial-CompartilhaIgual) 2.0 Genérica.

${ }^{c}$ Disponível em http://www.flickr.com/photos/lennartt/7236405528/, sob licença CC BY (Atribuição) 2.0 Genérica.

produção das enzimas $B$, pois não há substrato (pigmento 2) para que elas o transformem em verde (pigmento 3). Os pulgões também não ficam rosados, pois, apesar de haver substrato para a produção do pigmento rosa, não há enzimas do tipo $A$ que desempenhem tal função.

Tal via metabólica pode ser modelada de diversas maneiras. Uma delas seria representar os pigmentos por nós e os processos de transformação feitos pelas enzimas por arestas. Outra maneira seria representar apenas as enzimas por nós e indicar com arestas que estas proteínas interagem. A maneira mais completa é representar tanto os pigmentos 
como as proteínas como nós e indicar o que processa e produz o que e em que sentido por meio de arestas direcionadas. Uma representação visual dessa abordagem é exibida na Figura 2.

Não há somente interações de transformação na biologia, há também, interações de inibição, por exemplo, entre outras. Cada interação ou via completa pode acontecer em determinada partição da célula, por exemplo, no citoplasma, no núcleo, entre outras. Essas regiões são chamadas partições celulares ou cellular component. Uma proteínas pode participar de mais de uma via metabólica. Uma via metabólica pode acontecer inteiramente em uma partição celular ou parte em uma e parte em outra, ou mais.

Figura 2 - Representação visual de uma via metabólica da espécie Mus musculus conforme exemplo da Figura 1. Os vértices representam as enzimas e os pigmentos. A direção e o tipo das arestas indicam qual pigmento é substrato e qual pigmento é produto de qual enzima.

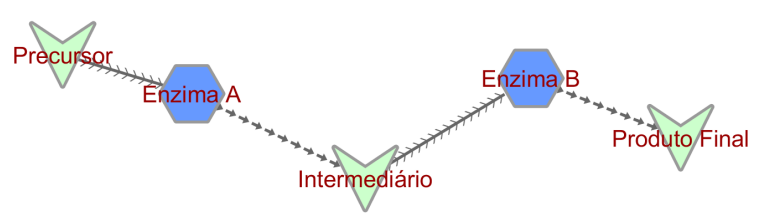

Por exemplo, as vias metabólicas relacionadas a cor de uma ave, cujas penas possuem muitas cores, podem ser unidas e representadas pelo que é chamado processos biológicos. Nesse caso, pode-se ter um processo biológico ligado à definição das cores da ave e, consequentemente, ao indicar onde esse processo biológico acontece, tem-se, em geral, mais de um valor de partição celular. Cada via que participa desse processo pode acontecer em uma partição diferente.

$\mathrm{Na}$ biologia, as entidades possuem atributos que podem ter mais de um valor, os chamados atributos multivalorados. Sendo assim, o atributo "partição celular" de uma determinada proteína pode ter valores "núcleo", "citoplasma" e "membrana" porque ela participa de um processo biológico que acontece (da entrada dos substratos ao processo até a criação dos produtos finais) nessas três partições.

Para ficar mais clara a complexidade desses sistemas biológicos, a subseção 2.1.1.1 e a subseção 2.1.1.2 descrevem em mais detalhes os seguintes tipos de interação: regulação da transcrição (expressão gênica) e regulação da catálise (atividade da proteína). Essas regulações têm ligação direta com o nível de expressão das proteínas e auxiliam no entendimento da causa das baixas ou altas concentrações. 


\subsubsection{Regulação da transcrição}

Cada gene de um DNA pode ser transcrito em uma molécula de ácido ribonucleico (RNA), que posteriormente é traduzido em uma proteína pela enzima RNA Polimerase. A molécula de RNA obtida pela transcrição é chamada RNA mensageiro (mRNA), derivado de sequências do DNA chamadas éxons, que são sequências do DNA que servem como molde para a tradução em proteína. Há no DNA, no mesmo gene, sequências que são descartadas e não fazem parte do mRNA, são chamadas íntrons (PIMENTEL; SANTOS-REBOUÇAS; GALLO, 2013).

O processo de transcrição de um gene se inicia em uma área do DNA chamada promotor. A enzima RNA polimerase se encaixa e inicia o processo de transcrição sequencialmente, base nitrogenada por base nitrogenada. Para o processo ser iniciado, são necessários os ativadores de transcrição. São moléculas que se encaixam ao DNA e ativam a transcrição do gene.

Na Figura 3 são representados três ativadores. Primeiramente o ativador A se encaixa ao DNA e ativa o encaixe do ativador B. Então, o ativador B se encaixa e ativa o encaixe do C. Por fim, o ativador C se encaixa e ativa o encaixe da enzima RNA polimerase, que é a região chamada promotor. A ativação do promotor permite o início da transcrição. Esse processo tem como produto o RNA mensageiro, que por meio do processo de tradução permite a produção de uma proteína. Essa sequência de acontecimentos pode ser representada por uma subrede que junto de outras formariam uma rede maior para ser analisada globalmente.

A expressão de um gene está relacionada a regulação de sua expressão. Essa regulação, na verdade, é da sua transcrição e se dá com as interações dos seus ativadores de transcrição e o promotor. Com isso, pode-se questionar se a falta de uma determinada molécula (por exemplo, o pigmento verde do caso dos pulgões) acontece porque devido ao ambiente uma determinada enzima foi inibida (regulação da catálise) ou porque houve mutação e o promotor de tal enzima (responsável pela produção dela) não pôde ser ativado (regulação genética).

Um exemplo deste tipo de regulação é apresentado na Figura 4. Trata-se de uma flor (morning glory) com duas variações, uma bem azul e uma sem o pigmento azul. A formação do pigmento azul se dá por meio de uma via metabólica. No entanto, essa via metabólica depende de uma enzima para ser processada. Por sua vez, a produção dessa enzima é regulada por uma proteína originada do gene ipmyb1. Ou seja, essa proteína (do gene ipmyb1) ativa a transcrição da enzima da via metabólica da cor. O caso em que ocorre a falta do pigmento azul acontece porque houve mutação no gene ipmyb1 (CHANG et al., 2005). 
Figura 3 - Processo de ativação e início da transcrição de um template de DNA. Em (a), a fita de DNA em questão ainda não foi ativada. Em (b), cada um dos ativadores atingiu as sequências reguladores da transcrição correspondentes - cada ativador se conecta a uma sequência específica. A transcrição nesta etapa foi ativada pelo promotor. Em (c), a transcrição já foi iniciada e o RNA polimerase está percorrendo a fita de DNA, base a base, e produzindo o RNA mensageiro. Posteriormente este RNA será traduzido em proteína.

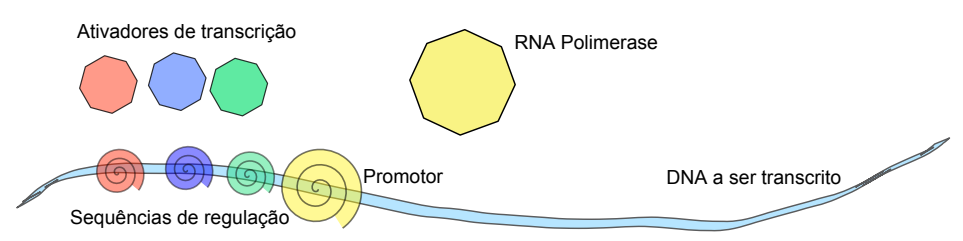

(a) Antes de se ativar a transcrição

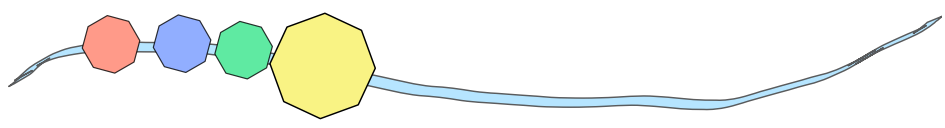

(b) Ativação da transcrição

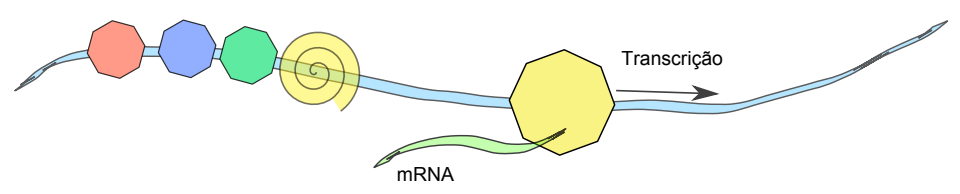

(c) Transcrição iniciada

Figura 4 - Fotografias de duas variações da flor Morning glory ocorridas por regulação genética. A proteína ativadora da transcrição da enzima da via metabólica da produção do pigmento azul sofre mutação com perda de função e passa a produzir flor branca.

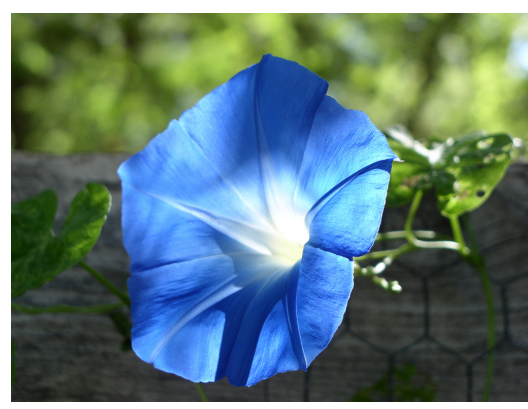

(a) Morning glory azul

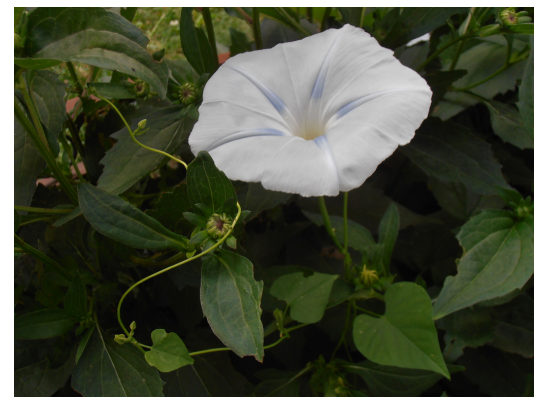

(b) Morning glory branca

Fonte: Fotografias das flores azul e branca disponibilizadas respectivamente por: Jason A. Samfield ${ }^{a}$ e "Galladia" .

${ }^{a}$ Disponível em http://www.flickr.com/photos/jason-samfield/6267142643/, sob licença CC BY-NC-SA 2.0 Genérica.

${ }^{b}$ Disponível em http://www.flickr.com/photos/galladia/5940461007/, sob licença CC BY-NC-SA 2.0 Genérica. 


\subsubsection{Regulação da catálise}

A ativação de uma proteína ou de um complexo de proteínas está relacionada à presença ou ausência de um metabólito ou mais metabólitos conectados a ele. Algumas proteínas só interagem com outras se estiverem ativadas, outras só são capazes de executar a catálise se estiverem ativas, entre muitas outras combinações de fatores.

Na Figura 5 há um exemplo de um complexo que só exerce sua função de transformar um pigmento azul em vermelho se houver também um metabólito que o ative. Pode-se pensar que tais reações são como um quebra-cabeça dinâmico: quando as enzimas estão ativas, as peças se encaixam.

Figura 5 - Exemplificação de dois processos diferentes de regulação de um catalisador. Em (a) uma proteína ativa a enzima responsável pela transformação de um pigmento em outro. Em (b) uma proteína que está ligada à enzima que transforma um pigmento em outro tem papel de inibidora. Essa inibição é ativada se houver metabólitos ativadores da inibição. No exemplo, um metabólito se encaixa à proteína inibidora e não permite a catalização, impedindo que o pigmento 1 seja transformado em pigmento 2.

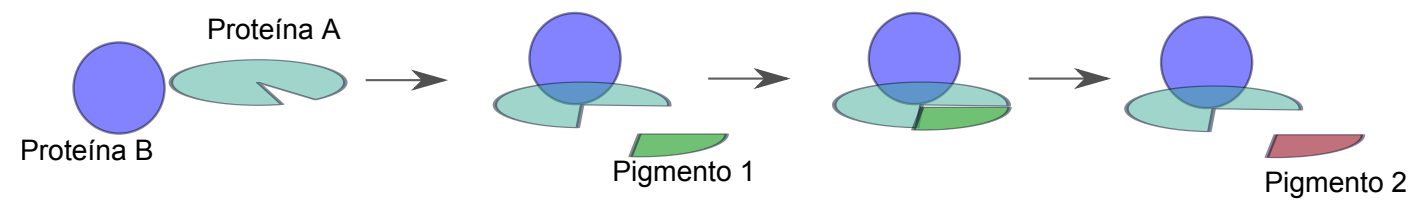

(a) Regulação por proteína

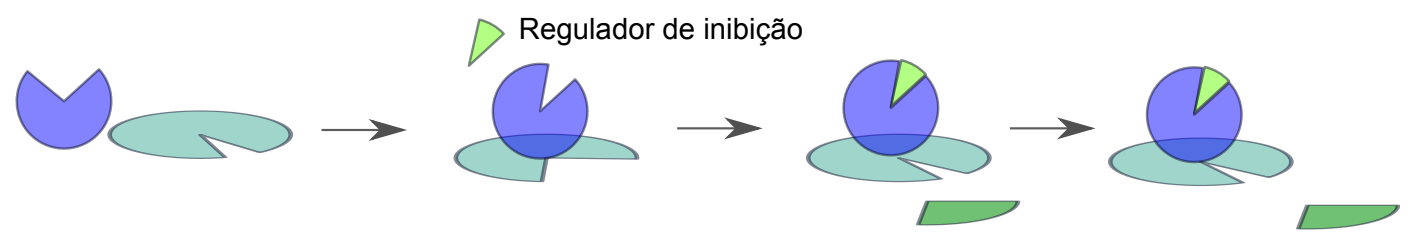

(b) Regulação de inibição por metabólito

Devido às dependências entre proteínas ou entre proteínas e metabólitos, dá-se o nome de regulação da catálise ao processo, em outras palavras, regulação das enzimas. Diferentemente da regulação dos produtos dos genes (regulação da produção das proteínas), as proteínas são reguladas mesmo após terem sido produzidas a partir dos genes também regulados (regulação da atividade das proteínas que já existem, chamada de regulação pós-traducional).

\subsection{Conjuntos}

A palavra conjunto pode ter dois significados, dependendo do contexto onde for utilizada: conjunto de dados ou conjunto matemático, da teoria dos conjuntos. Quando se analisa conjuntos na teoria dos conjuntos, não importa do que os elementos são formados. 
O que importa é que eles formam conjuntos. Quando se trata de conjunto de dados, mesmo que uma rede seja simplificada, tratando seus vértices como um conjunto e suas arestas como outro conjunto, por exemplo, seus elementos terão atributos, armazenarão informação além do que a teoria dos conjuntos se propõe a interpretar. Os elementos podem ter imagens, atributos numéricos, textuais, entre outros.

Apesar da complexidade dos conjuntos de dados, consegue-se utilizar conceitos da teoria dos conjuntos sobre eles. Além disso, técnicas de visualização dessa área também são aplicáveis. Um exemplo são os diagramas de Venn que permitem a interação para a visualização de informações, que os diagramas de Venn matemáticos não permitem (pois são apenas representações estáticas, sem interação).

Na biologia molecular a ideia de simplificação dos dados para que fiquem próximos de um conjunto da teoria de conjuntos é muito utilizada. Uma rede de proteínas pode ser vista como conjuntos de proteínas, em que os elementos são seus respectivos nomes. A mesma ideia pode ser utilizada para metabólitos, genes, entre outras entidades. Os diagramas de Venn e as operações de união, intersecção e outras, são muito utilizadas na área a fim de permitir comparações dos sistemas biológicos. Nas próximas subseções são definidos os conceitos básicos da teoria dos conjuntos e as técnicas de visualização relacionadas.

\subsubsection{Teoria dos conjuntos}

A notação usada nesta dissertação é a seguinte. Conjuntos são representados por letras maiúsculas e seus elementos por minúsculas. O tamanho de um conjunto $A$ é denotado por $|A|$ e denominado cardinalidade. O conjunto universo é denotado por $U$ e o conjunto vazio é denotado por $\emptyset$.

A relação de continência entre conjuntos é denotada por $\subseteq$ ou $\supseteq$ e a relação de continência estrita por $\supset$ ou $\subset$.

A união entre dois conjuntos $A$ e $B, A \cup B$, é o conjunto que contém todos os elementos de $A$ e de $B$. Portanto, se $A=\{a, b, c\}$ e $B=\{a, b, d, e\}$, então $A \cup B=$ $\{a, b, c, d, e\}$.

A intersecção entre conjuntos é definida pelos elementos que pertencem a todos eles. Para os dois mesmos conjuntos $A$ e $B$, descritos acima, a intersecção $A \cap B$ é igual a $\{a, b\}$, pois somente estes dois elementos aparecem em ambos os conjuntos.

Definições e notações como as apresentadas seguem o padrão adotado por textos consolidados, como Roman (1989) e Lovasz, Pelikan e Vesztergombi (2003).

Na subseção 2.2.2 são descritas características quanto à Visualização de Informação relacionada a conjuntos. 


\subsubsection{Técnicas de visualização de conjuntos}

Ao analisar um conjunto de dados em geral, procura-se identificar características como a cardinalidade e a homogeneidade do conjunto, entre outras. Também são analisadas características que dependem do analista e da tarefa, como a identificação de clusters, por exemplo.

As técnicas de visualização de informação apoiam o analista em sua tarefa de tirar conclusões sobre o conjunto a partir das características que encontra. Aspectos visuais de cor, forma, tamanho e outros, podem ser utilizados para representar um elemento de um conjunto em um diagrama.

Quando se trata de visualização de conjuntos simples, como conjunto de palavras ou números, usualmente são empregados diagramas simples. Em livros que descrevem a Teoria dos Conjuntos, vê-se muitos diagramas formados por elipses e alguns pontos. Outro exemplo é a representação de intersecção por meio da sobreposição de parte de dois círculos. Um exemplo pode ser visto na Figura 6. Nela, dois conjuntos são mostrados em forma de círculo, um representando uma coleção de números inteiros divisíveis por 3 , outro representando os divisíveis por 5 e a sobreposição de parte das elipses representando números divisíveis por 3 e por 5 .

Figura 6 - Diagrama representando dois conjuntos. O conjunto A, com alguns números inteiros múltiplos de três e o B, com múltiplos de 5. A sobreposição dos círculos representa a intersecção dos conjuntos. É fácil perceber quem são os elementos divisíveis por três e também por cinco.

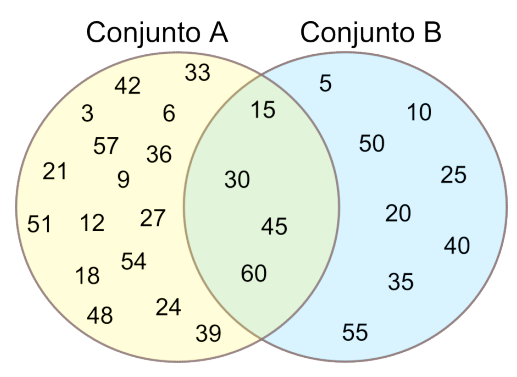

Duas maneiras clássicas de exibir informações de relações entre conjuntos são os diagramas de Euler e os diagramas de Venn. Euler citou sua primeira ideia sobre os diagramas em um conjunto de cartas enviadas de 1760 a 1763 à Princesa de Anhalt Dessau. Nelas, muitos assuntos eram tratados, de diversas áreas. Um deles era a representação de lógica de preposições e silogismos (SANDIFER, 2007).

Uma forma de silogismo é chamado de afirmativo particular: parte de A é B. Euler ilustra essa e outras afirmações por meio de um diagrama como o exibido na Figura 7 , que permite várias interpretações. Entre elas estão: algum $A$ é $B$, algum $B$ é $A$, algum $A$ não é $B$, algum $B$ não é $A$ (SANDIFER, 2007). Além da interpretação direta da figura, é possível justificar argumentos lógicos como: 
Figura 7 - Diagrama de Euler que pode ser interpretado como: algum $A$ é $B$, algum $B$ é $A$, algum $A$ não é $B$, algum $B$ não é $A$ (SANDIFER, 2007).

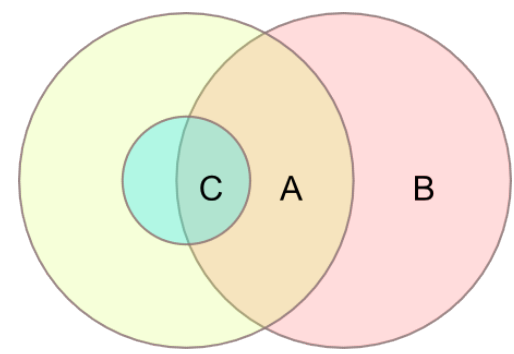

Fonte: Figura baseada em exemplo de Sandifer (2007).

a) Algum $C$ é $B$.

b) Todo $C$ é $A$.

c) Logo, algum $A$ é $B$ (SANDIFER, 2007)

Euler não percebeu a necessidade de indicar que algumas regiões poderiam ser vazias. Essa é a principal mudança que Venn propôs ao que ele próprio chamou de "círculos eulerianos" (SANDIFER, 2007).

Venn percebeu que poderia representar todas as combinações marcando os espaços que indicariam o vazio e dessa maneira poderia visualizar com um diagrama de círculos, proposições como "todo $A$ é $B$ " , como o da Figura 8 (SANDIFER, 2007). Não seria necessário o uso de círculos dentro de círculos para dizer, como o exemplo da Figura 7, que todo $C$ é $A$. Essa é a principal diferença entre os diagramas que hoje são conhecidos por diagramas de Venn e diagramas de Euler. Com isso, iniciou-se o estudo de como representar mais conjuntos em um único diagrama de Venn. Venn propôs um diagrama formado por cinco formas, quatro elipses e uma com forma de toro.

Figura 8 - Diagrama de Venn que pode ser interpretado como: todo $A$ é $B$ e nem todo $B$ é $A$. A região listrada do diagrama indica vazio.

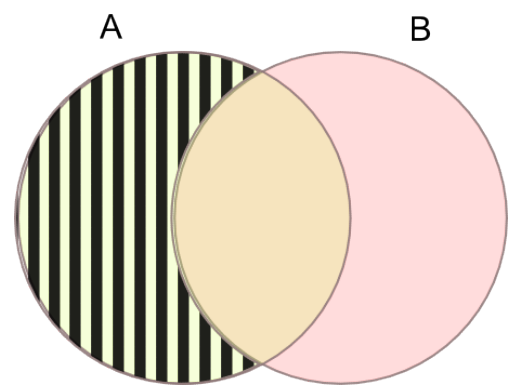

Fonte: Figura baseada em exemplo de Sandifer (2007).

É possível representar todas as combinações de conjuntos com formas disformes, mas não se tornam bons diagramas para serem analisados. Por isso, muitos começaram a estudar maneiras de representar tais combinações com formatos padronizados. Ou seja, 
diagramas formados por apenas elipses, apenas círculos, apenas triângulos, ou outras formas.

Também são estudadas possibilidades de variar o tamanho das formas de acordo com o tamanho do conjunto que cada uma representa e de deixar o diagrama simétrico por rotação (simetria rotacional) ou por reflexo (simetria axial). Com isso, começaram a surgir diagramas generalizados ou extensões dos diagramas de Venn, pois os diagramas simétricos tendem a ser limitados no número de conjuntos comparáveis e entendíveis por meio da visão humana.

Venn afirmou erroneamente que não seria possível formar um diagrama com cinco elipses ou círculos e muitos autores reafirmaram tal argumento por quase um século (HAMBURGER; PIPPERT, 2000) apud (GRÜNBAUM, 1992); sendo Schwenk (HAMBURGER; PIPPERT, 2000) apud (SCHWENK, 1984) quem primeiro publicou, em 1975, um diagrama de Venn com cinco elipses.

Atualmente, tem-se diagramas de Venn simétricos de até onze conjuntos (ver ??, o primeiro diagrama de Venn simples e simétrico de 11 conjuntos). Mas analisá-los não é uma tarefa simples. Algumas das melhores maneiras de representar em diagramas dois, três, quatro, cinco e seis conjuntos são mostradas na Figura 9. São diagramas com formas simples e interpretação não tão confusa. Com círculos é possível construir diagramas de até três conjuntos.

Para quatro e cinco, faz-se necessário o uso de elipses ou outras formas não circulares. Para mais conjuntos, os diagramas não simétricos, como o de seis conjuntos apresentado na Figura 9(e), são uma alternativa no contexto de visualização de informação. Contudo, a utilização deste tipo de diagrama não é eficaz para mais conjuntos, pois a "rosa" do centro do diagrama passa a ser muito complexa. Se utilizar um diagrama em forma de "rosa" para representar todos os seis conjuntos, o entendimento do diagrama se torna muito mais complexo e ainda mais confuso do que a versão onde duas "pétalas" são substituídas por retângulos.

Os diagramas apresentados na Figura 9 não são as únicas soluções para seus respectivos números de conjuntos. É possível, por exemplo, fazer diagramas para até sete conjuntos utilizando polígonos convexos. Nesse caso, para até seis conjuntos basta utilizar triângulos, mas para sete são necessário quadriláteros, como mostra a Figura 10 (CARROLL; RUSKEY; WESTON, 2007).

No formato de diagrama de "rosa", a configuração do diagrama para sete conjuntos fica ainda mais complexa e algumas possibilidades podem ser vistas na Figura 11. Esse tipo de representação pode ser chamada de diagrama de Edwards-Venn.

Por causa da dificuldade do entendimento de diagramas de mais de quatro conjuntos, Radcliffe (2010) propôs a utilização de diagramas aninhados, Nested Venn Diagrams. A 
Figura 9 - Exemplos de diagramas de Venn para dois, três, quatro e cinco conjuntos e diagrama de Edwards-Venn para seis conjuntos.

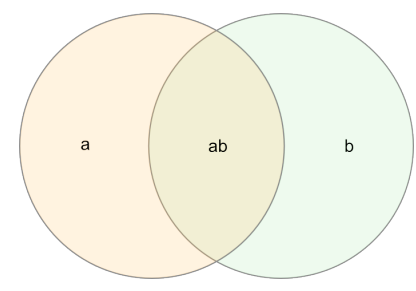

(a) Dois conjuntos

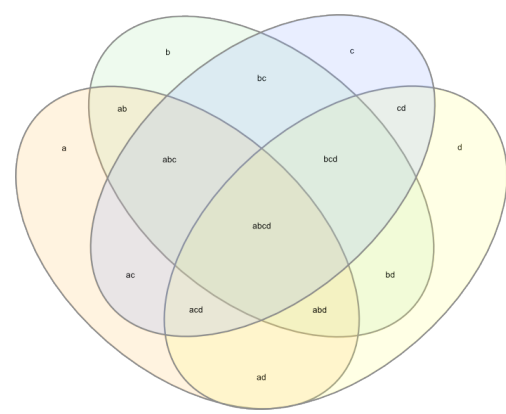

(c) Quatro conjuntos

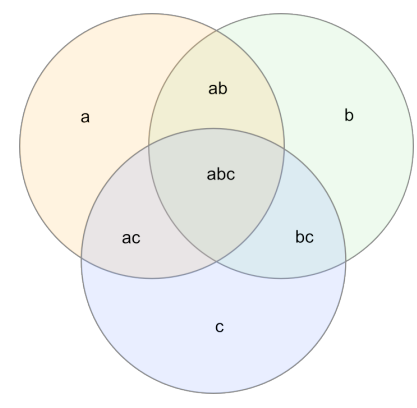

(b) Três conjuntos

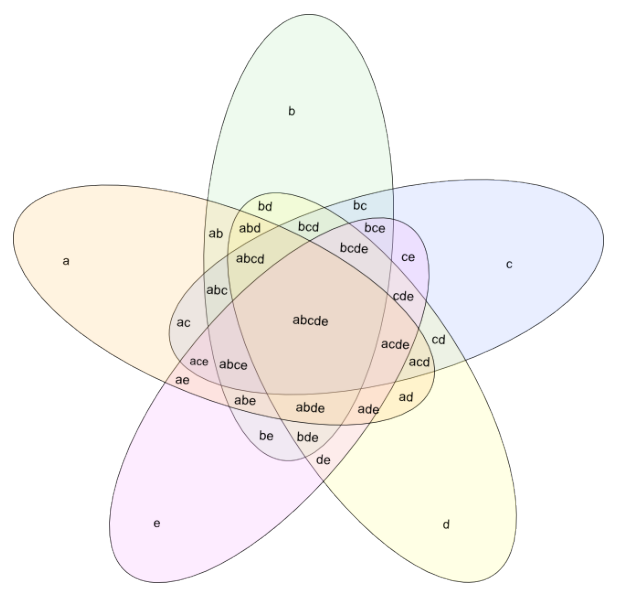

(d) Cinco conjuntos

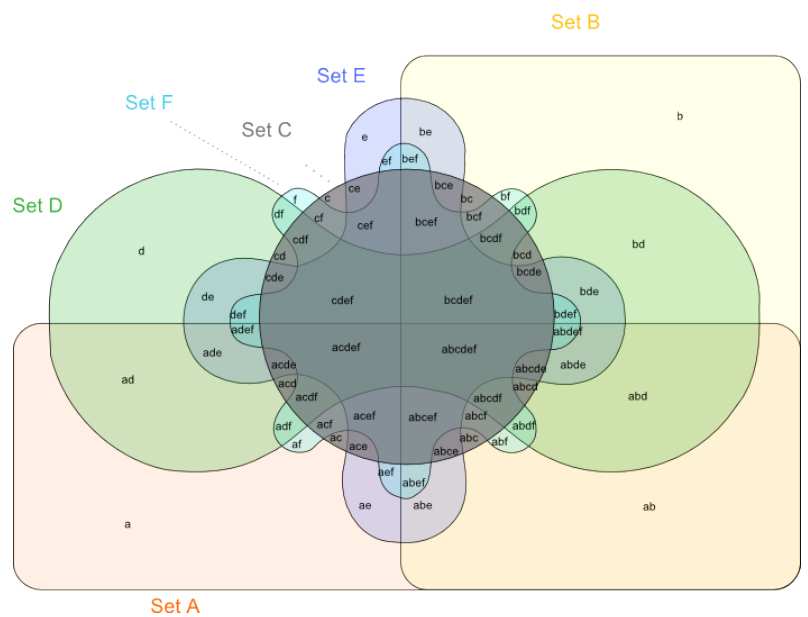

(e) Seis conjuntos

Fonte: Diagramas adaptados de < http://en.wikipedia.org/wiki/Venn_diagram $>$ 
Figura 10 - Exemplos de diagramas de Venn para seis e sete conjuntos.

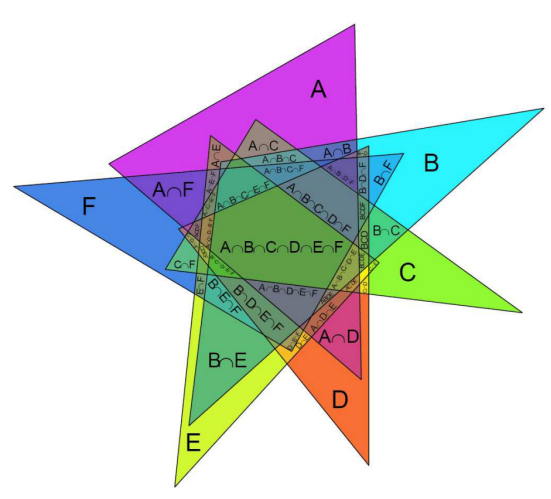

(a) Seis conjuntos

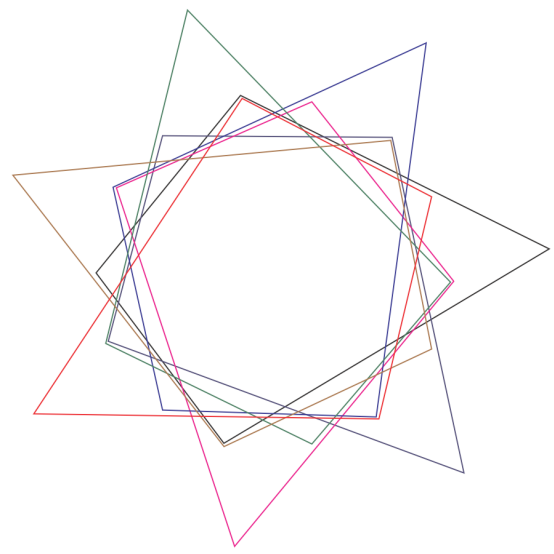

(b) Sete conjuntos

Fonte: Figuras de Carroll, Ruskey e Weston (2007). Copyright (c) 2007, Springer.

Figura 11 - Exemplo de alguns possíveis diagramas Edwards-Venn para sete conjuntos. Cada um dos diagramas representam sete conjuntos e todas as suas intersecções. Esse tipo de diagrama também é referenciado como em formato de rosa.

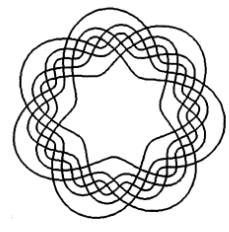

Adelaide
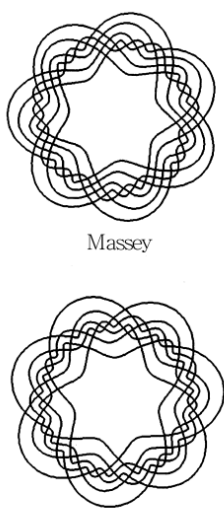

Palmerston North
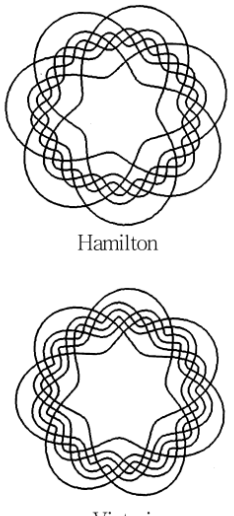

Victoria

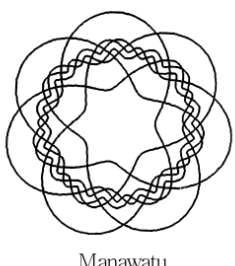

Fonte: Figura de Edwards (1998). Copyright (C) 1998, Cambridge University Press. 
Figura 12 - Exemplo de Nested Venn Diagram para até seis conjuntos. Trata-se de um tipo de extensão dos diagramas de Venn. A representação dos diagramas de Venn sobrepostos juntamente com uma representação separada (pequeno diagrama no canto inferior direito), satisfaz a condição de não ignorar nenhuma possibilidade de intersecção dos conjuntos requerida em diagramas de Venn.

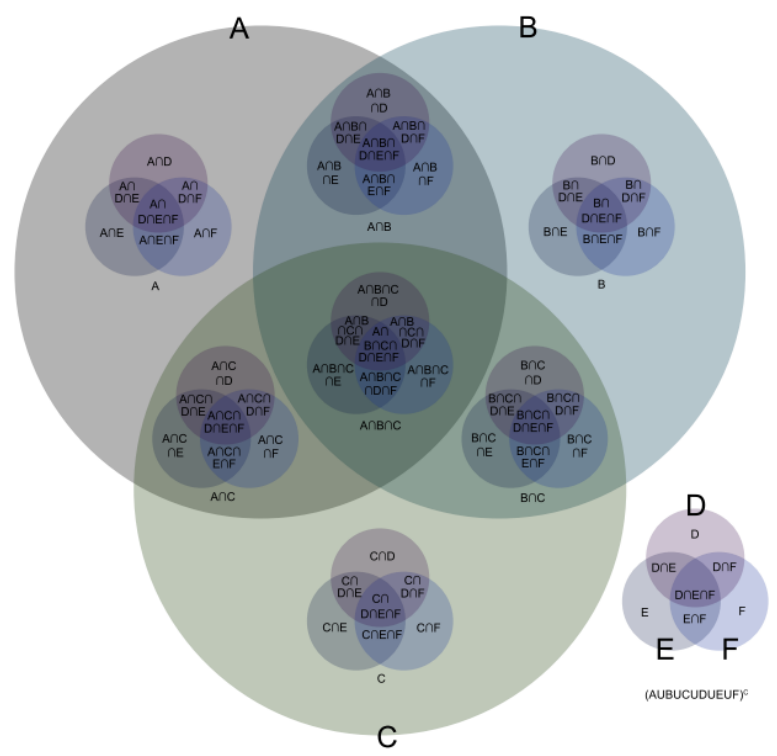

Fonte: Figura de Radcliffe (2010).

ideia é utilizar um diagrama em escala grande, para dois a quatro conjuntos, e um diagrama em escala menor, o "carimbo", também para poucos conjuntos, e "carimbar" o menor em todas as regiões de intersecções do maior e, adicionalmente, deixar uma versão do "carimbo" sozinha, sem estar sobre nenhuma região do diagrama maior, como na Figura 12. Com essa ideia é possível criar diagramas para mais conjuntos combinando os números de conjuntos de cada um dos dois diagramas que formam o diagrama aninhado. Em outras palavras, pode-se fazer diagramas de Venn estendidos para cinco a oito conjuntos.

Apesar de Radcliffe (2010) afirmar que é possível representar até oito conjuntos, sabe-se que, na verdade, poderiam ser representados até dez utilizando ainda apenas elipses, ou ainda mais conjuntos, por meio de outros formatos. Contudo, o nível de complexidade de entendimento aumenta muito a cada conjunto a mais considerado.

Outra possibilidade é utilizar a ideia de um diagrama de Euler estendido, ou Venn generalizado, e fazer com que o tamanho dos formatos sejam proporcionais às cardinalidades dos conjuntos, como na Figura 13. Usando a mesma estratégia há versões que utilizam retângulos e versões que utilizam decágonos (KESTLER et al., 2005; MARSHALL, 2005) . Por conta das limitações na representação das intersecções por formatos simples, esse tipo de diagrama não exibe todas as intersecções, pois não mostra intersecções vazias e, portanto, não se tornam diagramas de Venn. Em geral eles utilizam algoritmos de otimização para encontrar um bom tamanho e um bom posicionamento dos formatos, mas 
nem sempre estão corretos, possibilitando que o analista se engane. Nos casos em que 5 ou mais conjuntos possuem muitas intersecções (muitas regiões de intersecções diferentes) tais algoritmos de construção de diagramas acabam falhando mesmo na construção de diagramas de Euler. Algoritmos com proporcionalidade na forma funcionam melhor em casos em que há muitas intersecções vazias entre os conjuntos, ou em que há poucos conjuntos.

Figura 13 - Exemplo de digrama de Venn com formatos proporcionais à cardinalidade dos conjuntos.

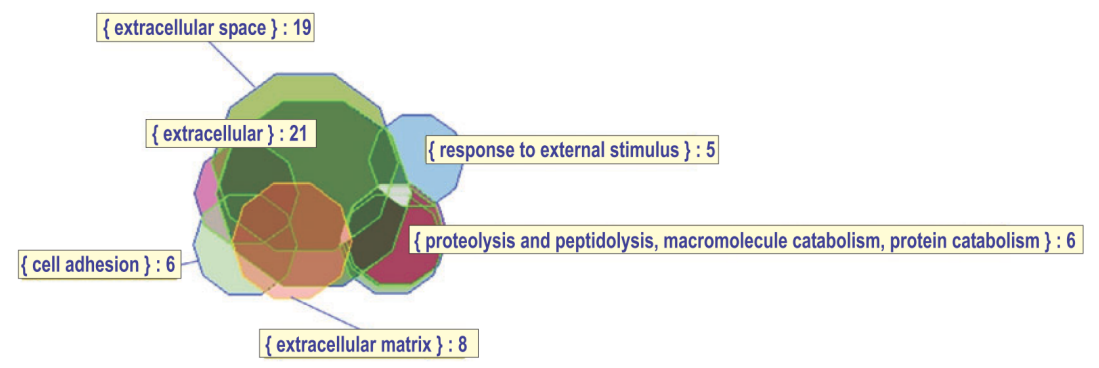

Fonte: Figura de Kestler et al. (2005). Copyright (C) 2005, Oxford University Press

\subsection{Grafos e redes}

A teoria dos grafos teve seu primeiro livro específico datado de 1936 e a maioria das publicações apareceram a partir de 1970 (NETTO, 2003, p. 5). Porém, com a invenção do computador, a teoria dos grafos progrediu e diversas aplicações foram encontradas em muitos outros campos da ciência. Seu desenvolvimento foi impulsionado pela necessidade de encontrar soluções a problemas de otimização. Essas tentativas e técnicas fazem parte do que hoje é chamado pesquisa operacional (NETTO, 2003, p. 6). Atualmente, a teoria de grafos é aplicada e estudada em diversas áreas da ciência, incluindo a biologia.

Grafos e redes são usados muitas vezes como sinônimos. Pode-se dizer que um grafo é um modelo matemático e uma rede é um grafo em conjunto de um contexto e informações ligadas a ele. Ou seja, uma rede, que tem um contexto na prática - uma rede social, uma rede biológica, entre outras - pode ser modelada matematicamente por um grafo.

Nesta dissertação, o termo grafo foi utilizado para representar modelos e propriedades matemáticas de uma rede. Já o termo rede foi empregado quando se trata de visualização de informação.

Na seção seguinte é apresentada uma introdução à definição de grafos e uma breve revisão sobre visualização de redes. 


\subsubsection{Definição de grafos}

Um grafo pode ser visto como um conjunto de vértices e arestas, sendo os vértices os pontos (nós) e as arestas ligações entre esses pontos (conexões), como uma rede. Na Figura 14 há a representação de um grafo em forma de um diagrama de vértices e arestas.

Figura 14 - Diagrama representando um grafo $G$, com vértices $a, b, c$ e $d$, e arestas $e 1, e 2$, $e 3$ e $e 4$.

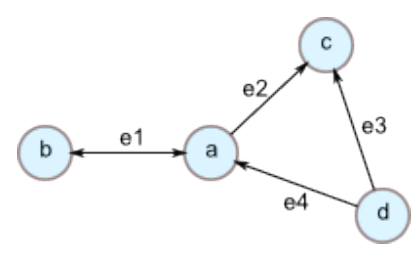

Tipicamente identifica-se o conjunto formado por todos os vértices de um grafo pela letra $V$ (de vertices), e o conjunto de todas as arestas pela letra $E$ (de edges). O grafo $G$ da Figura 14 é formado pelos conjuntos $V=\{a, b, c, d\}$ e $E=\{e 1, e 2, e 3, e 4\}$. Deste modo, define-se um grafo $G$ como $G=(V, E)$.

Pode-se definir $E$ como sendo uma família de elementos do produto cartesiano $V \times V$, da forma $\left(v_{i}, v_{j}\right)$, indicando qual é o vértice de origem $\left(v_{i}\right)$ e o vértice destino $\left(v_{j}\right)$ da conexão (BERGE, 1973).

Se a ordem do par $\left(v_{i}, v_{j}\right)$ importar, o grafo é dito direcionado. Caso contrário, é chamado grafo não direcionado. Nesse segundo caso, se houver a conexão $\left(v_{i}, v_{j}\right)$, obrigatoriamente haverá a conexão $\left(v_{j}, v_{i}\right)$. Portanto, se for identificado previamente que o grafo é não direcionado, pode-se definir $E$ usando apenas as conexões $\left(v_{i}, v_{j}\right)$, pois é redundante definir a conexão que sai de $v_{j}$ e chega em $v_{i}$ (BRANDSTÄDT; LE; SPINRAD, 1999).

Tomando o grafo $G$ da Figura 14 como direcionado, pode-se escrever o conjunto $E$ sendo igual a $\{(a, b),(b, a),(a, c),(d, c),(d, a)\}$. Caso as conexões $(c, a),(d, c)$ e $(a, d)$ também existissem, pode-se dizer que o grafo é não direcionado e, portanto, reescreve-se $E$ como $E=\{(a, b),(a, c),(d, c),(d, a)\}$.

\subsubsection{Visualização de redes}

Dentre as maneiras de se desenhar uma rede, estão as que posicionam os vértices (os indivíduos) em um espaço 2D ou 3D e os ligam por arestas e as que representam de outras maneiras, como a disposição em uma matriz. Exemplos são as ferramentas MatrixExplorer (HENRY; FEKETE, 2006) e NodeTrix (HENRY; FEKETE; MCGUFFIN, 2007), que apresentam além da abordagem comum (vértices e arestas), abordagens adicionais de representação de informação como matriz de adjacências.

Uma técnica comum para apoiar a visualização de redes é a de coordenação entre visões, como o Dual-Net (NAMATA et al., 2007) e o OntoVis (SHEN; MA; ELIASSI-RAD, 
2006). Por meio de duas visões o usuário explora a rede, sendo que as interações em uma visão traz resultados na outra visão.

Existem muitas ferramentas de visualização de redes, sendo o Gephi (BASTIAN et al., 2009) e o Cytoscape (SHANNON et al., 2003; SMOOT et al., 2011) muito utilizadas na área de biologia para a representação e exploração visual. Ambas as ferramentas possuem uma comunidade que estendem suas funcionalidades por meio de plugins, deixando-as mais poderosas e específicas para determinados tipos de análises.

Um dos grandes desafios da visualização de redes é com relação à interpretabilidade de grandes redes, que envolvem, por exemplo, 10 mil vértices e um número muito maior de arestas. Dez mil vértices é difícil de interpretar mesmo com poucas arestas, porém, com muitas arestas, o problema fica ainda maior, pois não se consegue nem perceber padrões de conexão por meio da visão. A representação das arestas acaba se tornando um plano colorido ao fundo dos vértices. Para esse tipo de problema, Longabaugh (2012) desenvolveu uma nova técnica de visualização de redes. Essa técnica, implementada na ferramenta Biofabric, trata os nós como linhas horizontais de uma dimensão, em oposição à maneira tradicional de representá-los como símbolos que se comportam como pontos em zero dimensões. Já as conexões da rede são desenhadas como linhas verticais no plano. É uma maneira de planificar tal "novelo de lã", que é formado pelas arestas em redes grandes e densas. Um exemplo é exibido na Figura 15.

Figura 15 - Exemplo de rede representada na ferramenta Biofabric.

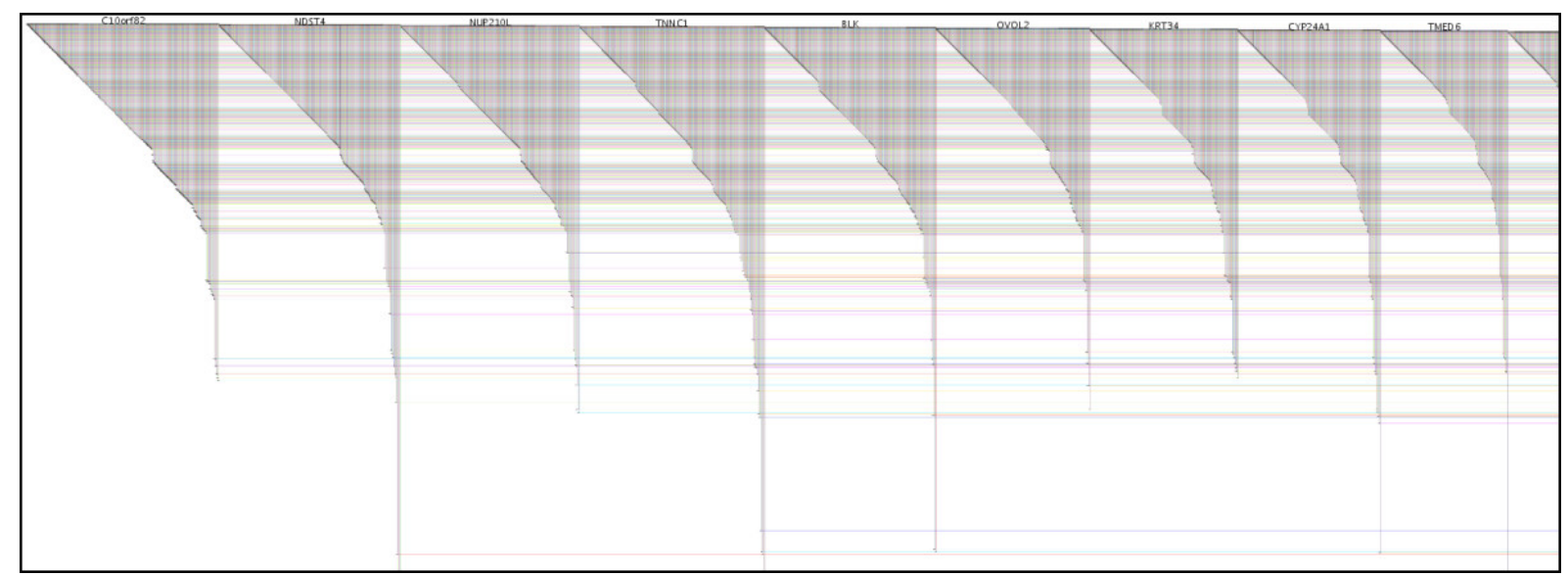

Fonte: Figura de Longabaugh (2012), sob licença CC BY 2.0 Genérica.

Na visualização de diagramas vértice-aresta tradicionais é preciso definir quais características no desenho facilitam a análise. Exemplos são a variação dos formatos dos vértices e arestas, das cores e dos tamanhos, entre outros aspectos visuais.

Uma abordagem que pode ser utilizada em redes é posicionar os vértices calculando uma medida de similaridade entre eles por meio de seus atributos. Assim, indivíduos seriam posicionados no espaço de tal forma que indivíduos semelhantes tendam a ficar 
próximos (MARTINS et al., 2012). Essa abordagem possibilita uma análise focada no comportamento dos relacionamentos, por exemplo, de acordo com os grupos de indivíduos formados. Entre as técnicas que posicionam os vértices no espaço bidimensional, estão, por exemplo, as baseadas em forças. Elas simulam sistemas físicos com conceitos de atração e repulsão. Um exemplo deste tipo de algoritmo é descrito em (KAMADA; KAWAI, 1989), em que vértices são conectados entre si por uma mola de desejável comprimento e o layout é considerado ideal quando a energia total do sistema de molas é mínima.

\subsubsection{Técnicas visuais de análise de relações entre redes}

Um dos métodos de se representar visualmente duas ou mais redes para a comparação delas é o lado a lado. Ele é o mais comum por proporcionar uma comparação de forma direta, comparando-as separadamente. Neste método, as redes são representadas por alguma técnica de visualização de redes e são exibidas simultaneamente, possibilitando a comparação por meio da visão de ambos os desenhos. Técnicas de coordenação facilitam a localização dos nós nas visões. Além da coordenação, pode-se criar ligações explícitas entre nós de redes distintas, formando uma única rede, para exibir as informações de relações desejadas. Um exemplo pode ser visto na Figura 16. Nessa abordagem, além do cuidado que se deve ter com relação ao posicionamento dos nós de cada uma das redes, é necessária uma atenção para o posicionamento dos nós como um todo, para que seja fácil analisar tanto as relações intra-redes como as inter-redes. Em outras palavras, é preciso posicionar sem deixar a visão muito poluída.

Figura 16 - Comparação de redes lado a lado. As relações entre vértices das redes diferentes são exibidas também em forma de arestas, indicando algum tipo de relação. Tal relação pode ser de igualdade, de semelhança, entre outras.

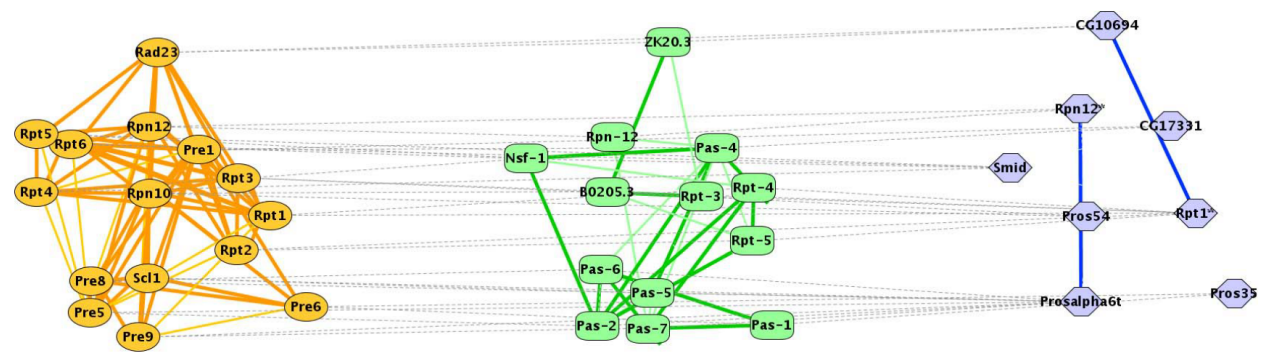

Fonte: Figura de (BRASCH; LINSEN; FUELLEN, 2007), Copyright (C 2007 IEEE.

É justamente esse o principal problema da abordagem. Quando se está analisando duas ou mais redes de grande escala o campo de visão se torna limitado, o que inviabiliza a comparação devido ao grande número de cruzamento de arestas e sobreposição de vértices. Faz-se necessário o uso de mais de um monitor, o que também prejudica a análise - pois as redes podem ficar muito longe no campo de visão do usuário, impedindo que 
alguma informação seja descoberta por limitações da visão e mente humana, que seriam descobertas se as redes estivessem próximas.

Outra técnica para permitir a comparação é unir todas as redes em uma só, de tal forma que seja possível identificar a que redes um determinado nó, ou conjunto de nós, pertence. Então, neste caso, os nós equivalentes de redes diferentes seriam convertidos em apenas um nó e as ligações deles seriam representadas neste novo nó (SHARAN; IDEKER, 2006).

Uma nova rede é formada nessa técnica que tenta preservar o espaço do display, em oposição à técnica lado a lado. Porém, essa representação gera problemas de interpretação. Entre eles estão a identificação das redes a qual uma aresta ou um vértice pertence e, no caso da identificação de outras entidades, como pequenos grupos de vértices da rede, pode ficar ainda mais confuso. Isso porque as alternativas que restam para as diferenciações são o uso de cores e formas.

Num contexto em que se quer comparar várias redes é possível que haja tanta mistura de cores e formas que o diagrama fique ilegível e a análise prejudicada. Por exemplo, se uma aresta existe numa rede $A$, então ela é amarela; se existe na rede $B$, é azul; e se existe em ambas? Poderia ser verde, ou representar duas linhas, uma azul e uma amarela.

Essa mistura de cores se torna complexa em comparações de mais de duas redes, ou em redes em que há mais de um tipo de conexão entre dois vértices. Com as Figuras 17 e 18 pode-se perceber quão confuso o diagrama fica ao se aumentar o número de redes.

Figura 17 - Comparação de duas pequenas redes, uma representada pela cor amarela e outra pela cor azul. A cor verde indica vértices alinhados entre duas redes ou vértice em comum.

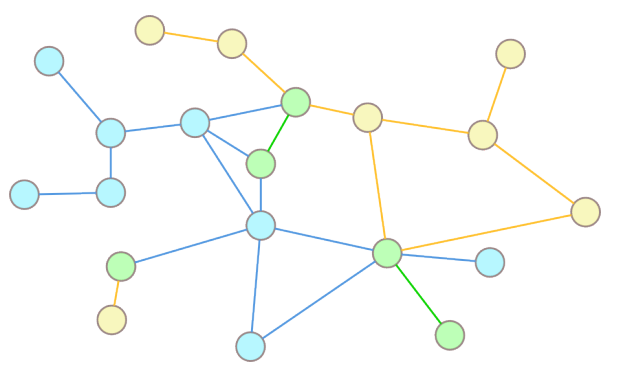

O mesmo ocorre com o caso de alinhamento de nós de redes diferentes (indivíduos diferentes sendo igualados). Ou seja, um indivíduo de uma rede poderia ser representado junto de outro indivíduo, formando um novo vértice no grafo. Assim, a representação visual teria de exibir, além das variações de arestas, quais vértices são representados por um determinado nó e de que redes esses vértices vieram.

Um exemplo geral sobre as técnicas descritas é exibido na Figura 18, em que três redes são comparadas, em forma de uma só. Usou-se cores e também representação por forma e cor para indicar repetição de vértice (ou alinhamento). Percebe-se que o diagrama 
Figura 18 - Comparação de três pequenas redes, cada uma representada por uma cor, entre verde, amarelo e vermelho. As outras cores indicam vértices em comum ou vértices alinhados entre as redes. Por exemplo, a cor verde indica vértices alinhados ou comuns entre a rede em amarelo e a rede em azul. São também identificadas as redes por meio de forma e cor, cada uma separadamente, dentro do nó intermediário.

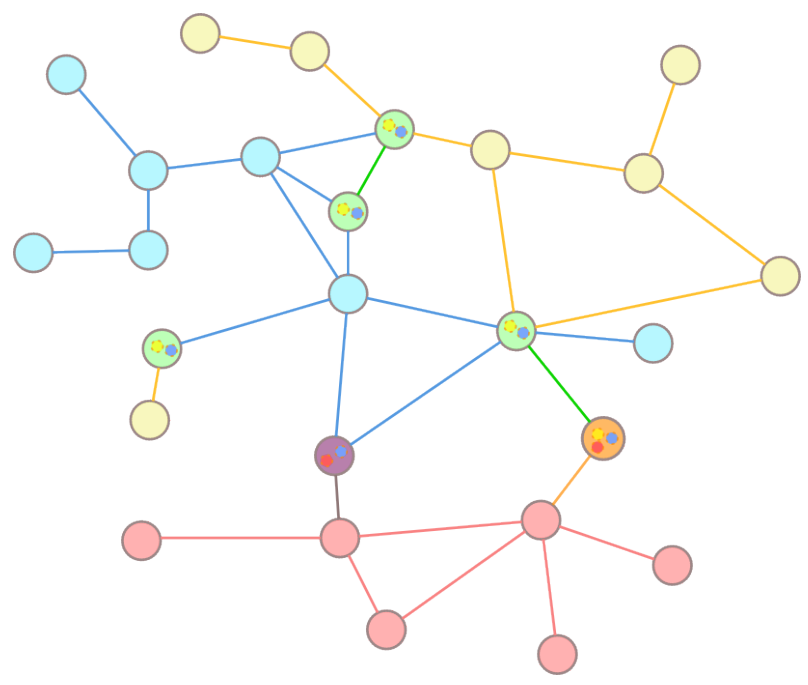

é bem colorido e que se fossem redes de três mil vértices cada uma, certamente o layout não seria muito limpo ou fácil de entender.

\subsection{Relações entre conjuntos e redes}

Qualquer rede ou conjunto de redes pode ser visto como conjuntos de elementos, sejam eles os próprios vértices ou arestas ou os valores relacionados a eles. Com isso, técnicas de visualização de conjuntos podem ser utilizadas para identificar informações que por meio de técnicas de visualização de redes não poderiam ser encontradas. A utilização de técnicas de visualização de conjuntos em redes não substitui as técnicas nativas desse tipo de dado. Essas técnicas podem ser utilizadas em conjunto, expandindo o potencial da análise.

Um exemplo de utilização dessa abordagem é o plugin Venn-cytoscape-plugin ${ }^{3}$ da ferramenta Cytoscape. Com ele é possível coordenar diagramas de Venn com redes. A interface gráfica da ferramenta com uma demonstração pode ser vista na Figura 19. No exemplo da Figura 19 são representados dois conjuntos e uma rede. Ao selecionar uma partição do conjunto, os seus elementos são destacados na rede. Esse plugin serviu como motivação para este trabalho de mestrado, na medida que a utilização de diagramas de Venn pode ser feita de outras maneiras para o entendimento das informações contidas nas redes que se quer analisar. Essas informações podem ser sobre as vias (metabólicas, transcrição, etc.), as moléculas, a localização das mesmas, entre diversas outras. Em geral,

\footnotetext{
${ }^{3}$ http://www.dishevelled.org/venn-cytoscape-plugin/
} 
são codificadas como arestas, nós e atributos destes dois.

Figura 19 - Interface gráfica do plugin Venn-cytoscape-plugin da ferramenta Cytoscape.

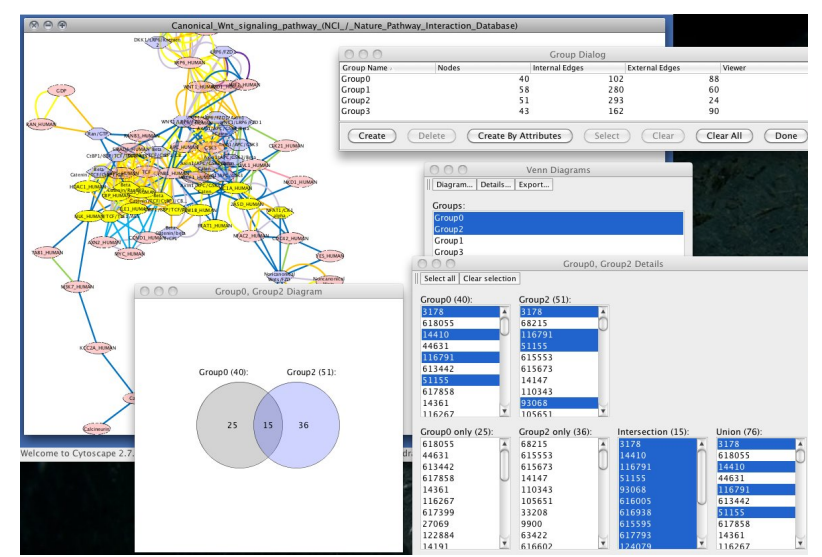

Fonte: http://www.dishevelled.org/venn-cytoscape-plugin/; acesso em 28/11/2012.

Nesse trabalho, focou-se em características que o Cytoscape e o Venn-cytoscapeplugin não possuem, pois não foram feitos para tratar de problemas como os tratados neste trabalho. Por exemplo, não é possível descobrir quais são os processos biológicos relacionados à algumas proteínas de uma rede e como esses processos estão distribuídos quando outras redes são consideradas.

De modo geral, as análises comparativas no contexto deste trabalho são feitas com relação aos elementos das redes, respondendo perguntas como "quais proteínas aparecem em uma rede e não aparecem em outra?", com relação aos valores dos atributos da rede, respondendo a perguntas como "quais as vias metabólicas que acontecem em uma rede e não acontecem em outra?", e com relação aos nós que possuem determinados valores e os que não possuem, respondendo a perguntas como "quais proteínas desempenham papel na transcrição e que não são reparadoras de DNA". A duas últimas perguntas são respondidas por meio de valores de atributos das redes, sendo a primeira pergunta respondida apenas com a utilização dos vértices dos respectivos grafos.

Esse tipo de análise requer funcionalidades de exploração que permitam ao mesmo tempo visualizar a rede, selecionar nós de interesse e analisar suas características. No Capítulo 3 é explicado em detalhes como o problema foi tratado por meio da utilização de técnicas visuais, relacionadas principalmente a análises comparativas. 


\section{Visualização comparativa de redes biomo- leculares}

No Capítulo 2 foram explicados conceitos básicos de sistemas biomoleculares. Foram detalhadas as origens biológicas dos dados, assim como as formas pelas quais eles podem ser modelados como grafos e analisados por meio de técnicas de visualização.

Entre as estratégias para analisar uma rede, há o caso em que o analista se preocupa não apenas com as informações da conectividade dos redes mas com as informações armazenadas em seus atributos, que podem ser, no caso da biologia molecular, o nível de expressão de uma molécula, a partição celular em que ela pode ser encontrada, o processo biológico da qual participa, entre outras.

Esse tipo de informação pode ser tratada por meio de conjuntos e analisadas comparativamente por meio de diagramas de Venn. Tais diagramas que por sua vez podem ser integrados à análise de redes, por meio da interação do usuário com a ferramenta visual.

Partindo desses princípios, uma nova abordagem de exploração utilizando diagramas de Venn foi desenvolvida, em que o usuário pode explorar os conjuntos visualizados por meio de operações de união sem precisar criar um novo diagrama. Essa abordagem é detalhada na seção 3.1. Na seção 3.2, é detalhada a maneira como a utilização de diagramas de Venn foi combinada com técnicas de visualização em redes para permitir análises comparativas.

\subsection{Diagramas de Venn interativos}

Diagramas de Venn são utilizados para encontrar semelhanças e diferenças entre conjuntos em diversas áreas. Há algumas ferramentas que podem ser utilizadas para a construção de diagramas a partir de conjuntos, como Pangloss Venn diagram generator $^{1}$ (SEIDEL, s.d.) e Venny ${ }^{2}$ (OLIVEROS, 2007).

No entanto, se o usuário quer analisar as semelhanças e diferenças da união entre dois conjuntos em relação a um terceiro, cabe a ele executar tais operações externamente e criar um novo diagrama com suas novas listas. Por exemplo, ao analisar um diagrama de cinco conjuntos e efetuar uma operação de união entre dois conjuntos e dois outros conjuntos, resultando em uma redução do número de conjuntos de cinco para três, ele teria que fazer isso separadamente. A partir desses três conjuntos, então, o usuário criaria um novo diagrama.

Além do trabalho da criação de novos diagramas, há o trabalho de reaprender o

\footnotetext{
${ }^{1}<$ www.pangloss.com/seidel/Protocols/venn4.cg $>$

${ }^{2}<$ www.bioin-fogp.cnb.csic.es/tools/venny/index.html $>$
} 
mapeamento dos conjuntos nesse novo diagrama que aparece para o usuário de forma diferente do primeiro diagrama. Pensando nesses dois problemas e procurando tornar esse tipo de análise mais rápida e mais informativa, foi criada uma técnica que permite ao usuário fazer operações de união sobre os conjuntos e refletir tais operações sobre as formas do diagrama original. À essa técnica deu-se o nome de InteractiVenn.

Para exemplificar a técnica, suponha que os conjuntos resultantes de três métodos de identificação de proteínas presentes em um determinado tecido estão sendo comparados. O diagrama de Venn dos conjuntos de proteínas de cada método é exibido na Figura 20. Pode-se perceber, pelo diagrama da Figura 20(a), que o Método 1 é relativamente parecido com o Método 2, devido à cardinalidade da intersecção entre eles ser muito maior que das intersecções deles com o Método 3.

Figura 20 - Diagrama de Venn de comparação de três métodos fictícios de identificação de proteínas. Em (a), é exibido o digrama que compara separadamente os três métodos. Em (b), é exibido o diagrama que compara o Método $3 \mathrm{em}$ relação a todos os outros. Trata-se da aplicação da técnica InteractiVenn para a visualização da união entre os conjuntos dos Métodos 1 e 2.

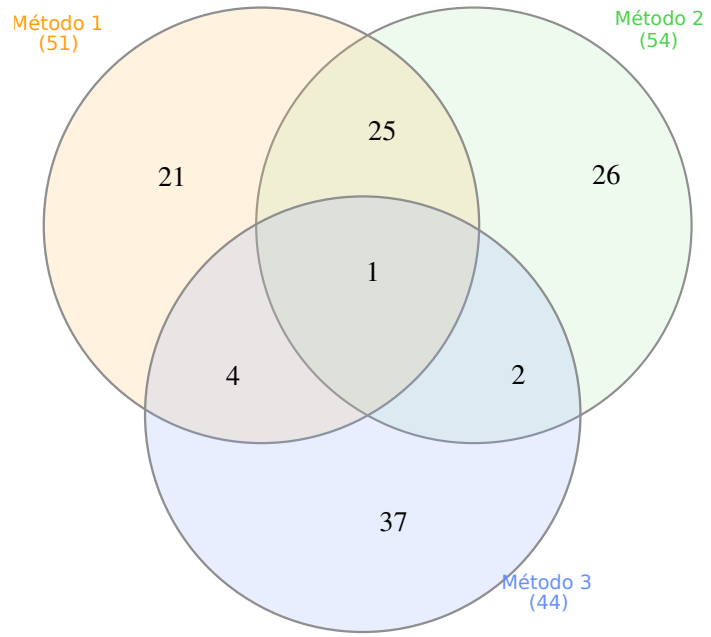

(a) Diagrama de comparação de três métodos

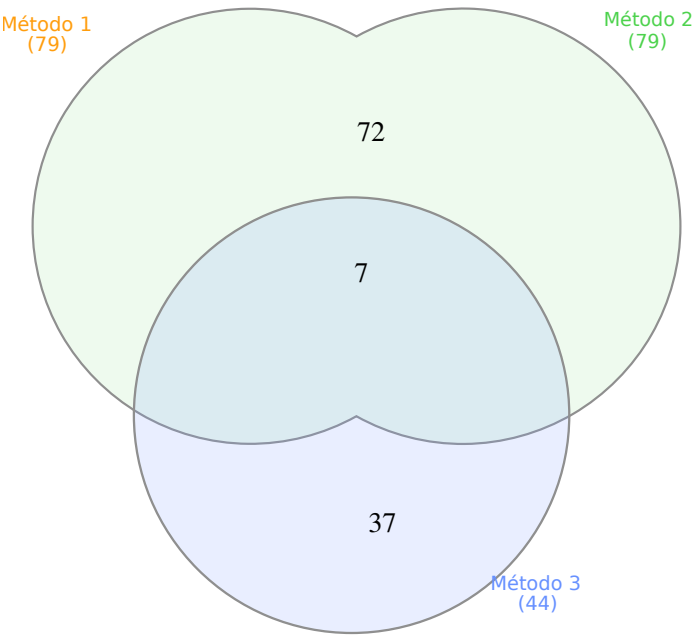

(b) União entre dois conjuntos para comparar com um terceiro

Supondo agora que, devido à um levantamento de hipótese, um suposto usuário quisera saber quais as proteínas resultantes dos Métodos 1 e 2 que não participaram do resultado do Método 3. Para isso, ele executou a união entre os Métodos 1 e 2 por meio da técnica InteractiVenn e obteve o diagrama apresentado na Figura 20(b). Neste diagrama ficam claras a diferença e semelhança do Método 3 em relação aos outros.

Esse tipo de comparação de listas é comum no dia a dia de pesquisadores de diversas áreas. Por esse motivo, criou-se uma ferramenta web, o InteractiVenn website, que implementa a técnica InteractiVenn para quaisquer conjuntos de cadeias de caracteres. Mais detalhes sobre o sistema são apresentados na subseção 3.1.1. 


\subsubsection{InteractiVenn website}

Um uso recente de um diagrama de Edwards-Venn é apresentado num artigo que trata do genoma da banana (Musa acuminata) (D'HONT et al., 2012). No artigo, os autores compararam a Musa acuminata em relação a algumas outras monocotiledôneas (plantas cujo embrião tem, tipicamente, um só cotilédone), e em relação a uma eudicotiledôneas (apresentam dois cotilédones), a Arabidopsis thaliana, planta presente em um dos casos de análise do Capítulo 4.

O diagrama de Edwards-Venn apresentado no artigo compara principalmente as monocotiledôneas entre si e em relação a planta modelo Arabidopsis thaliana. No entanto, esse diagrama foi adaptado para parecer mais contextualizado, de forma que um dos conjuntos apresentados no diagrama possui forma de uma banana. Esse formato é o que representa o conjunto referente à Musa acuminata. O diagrama pode ser visto na Figura 21.

Figura 21 - Diagrama de Edwards-Venn exibindo a distribuição de genes compartilhados entre seis espécies de plantas. O diagrama foi feito com o resultado de uma técnica de agrupamento que identifica os genes que podem ser considerados "iguais", tratando cada grupo identificado como um gene. Isso é feito em genes de uma mesma espécie e entre espécies diferentes. Os genes entre espécies diferentes, em sua maioria, não são os mesmos, portanto, técnicas de agrupamento são utilizadas para encontrar genes equivalentes.

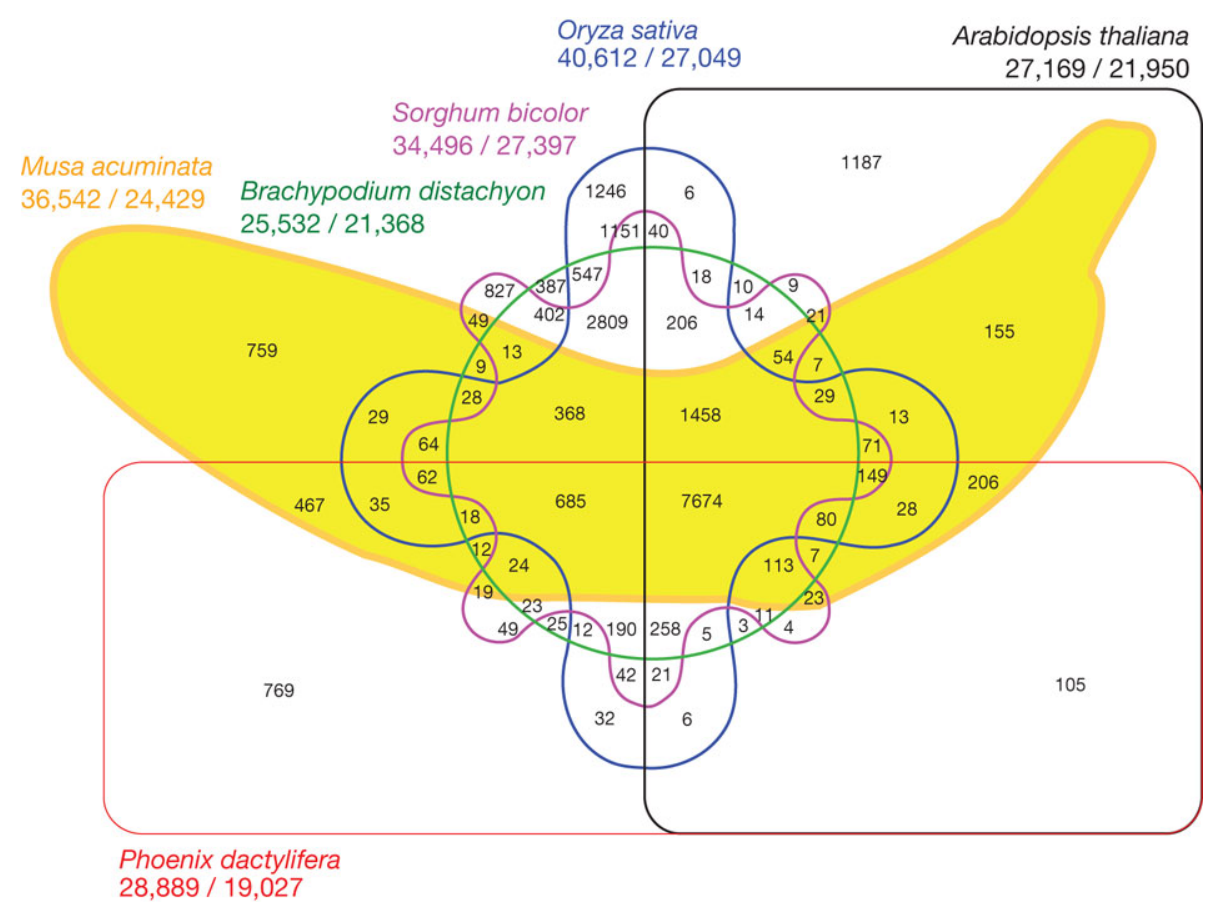

Fonte: Artigo de (D’HONT et al., 2012), sob licença CC BY-NC-SA 3.0 Genérica.

O artigo também apresenta um agrupamento entre espécies, distribuindo-as em uma árvore filogenética que indica a proximidade entre espécies com relação às semelhanças genéticas, e também com relação ao período em que elas surgiram. A representação visual da árvore é exibida na Figura 22. Nela é possível identificar que as espécies Oryza sativa 
e Brachypodium distachyon são muito semelhantes e que surgiram no período Terciário (Tertiary). Com esse exemplo, percebeu-se que comparar ambas as espécies pelo diagrama apresentado é difícil, assim como responder a perguntas como "A intersecção entre essas duas espécies é grande ou pequena?".

Figura 22 - Árvore filogenética distribuindo espécies pelas similaridades e também identificando seus períodos de surgimento.

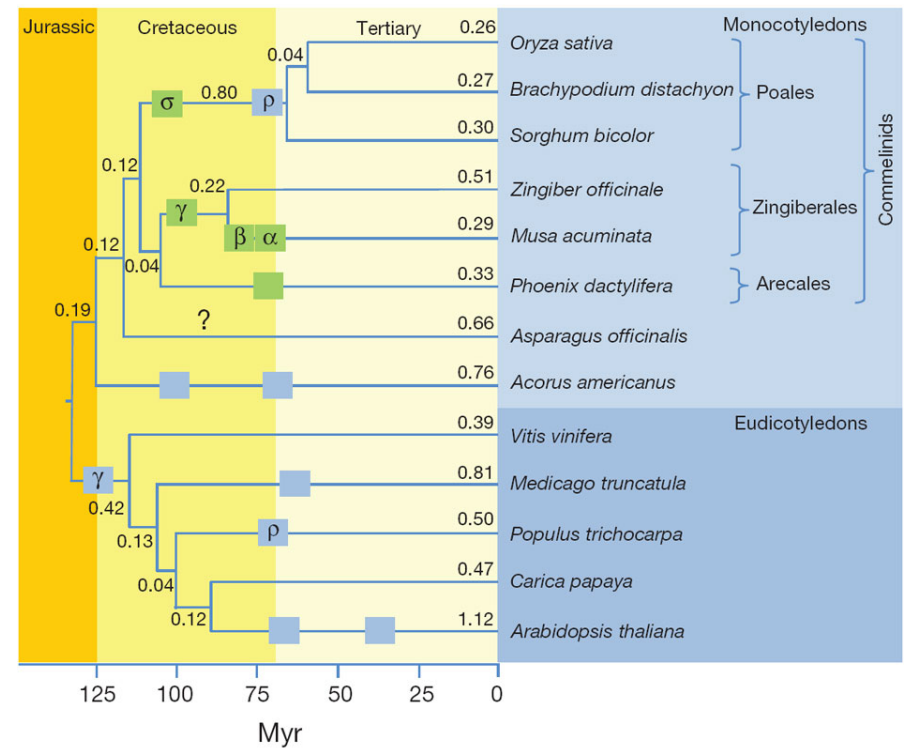

Fonte: Artigo de (D'HONT et al., 2012), sob licença CC BY-NC-SA 3.0 Genérica.

No entanto, se efetuarem a união entre todas as outras espécies com a técnica InteractiVenn, restam separadas apenas duas, Oryza sativa e Brachypodium distachyon. Com isso, é fácil verificar pelo diagrama (apresentado na Figura 23) a intersecção exclusiva delas (547 genes), em que genes que aparecem em outras espécies são desconsiderados, e a intersecção total delas $(547+13.838$ genes $)$, em que os genes que aparecem em outras espécies são considerados. A diferença entre as espécies se localiza nas regiões exclusivas (387, 1246, 1749 e 727 genes), que somadas resultam em 4.109 genes. Outras operações como essa podem ser feitas para se chegar a mais conclusões. Os dados para a reprodução do diagrama do artigo (D'HONT et al., 2012) foram fornecidos pelos autores.

Motivados por esse trabalho, criou-se uma ferramenta web, o InteractiVenn web, capaz de gerar diagramas a partir de listas de elementos. A tela principal do sistema pode ser vista na Figura 24. À esquerda se localiza o diagrama com que o usuário pode interagir, verificando quais são os elementos de cada intersecção por meio de pop-ups que são abertos ao clicar nos respectivos números. Acima do diagrama se localiza o campo em que o usuário pode definir uma sequência de operações de união entre os conjuntos que foram definidos à direta do diagrama, na região de entrada dos dados. $\mathrm{O}$ 
sistema InteractiVenn website foi baseado no layout do sistema Venny, a partir do qual as funcionalidades aqui apresentadas foram desenvolvidas. O InteratiVenn website está disponível em <http://www.interactivenn.net $>$.

Figura 23 - Comparação das espécies Oryza sativa e Brachypodium distachyon em um diagrama que exibe seis espécies. Para isso, efetuou-se a união entre todas as espécies, desconsiderando a Oryza sativa e a Brachypodium distachyon. A comparação das duas espécies se torna mais fácil do que se fosse feita no diagrama original em que as intersecções entre as duas estão divididas em muitas pequenas partes difíceis de serem localizadas no diagrama.

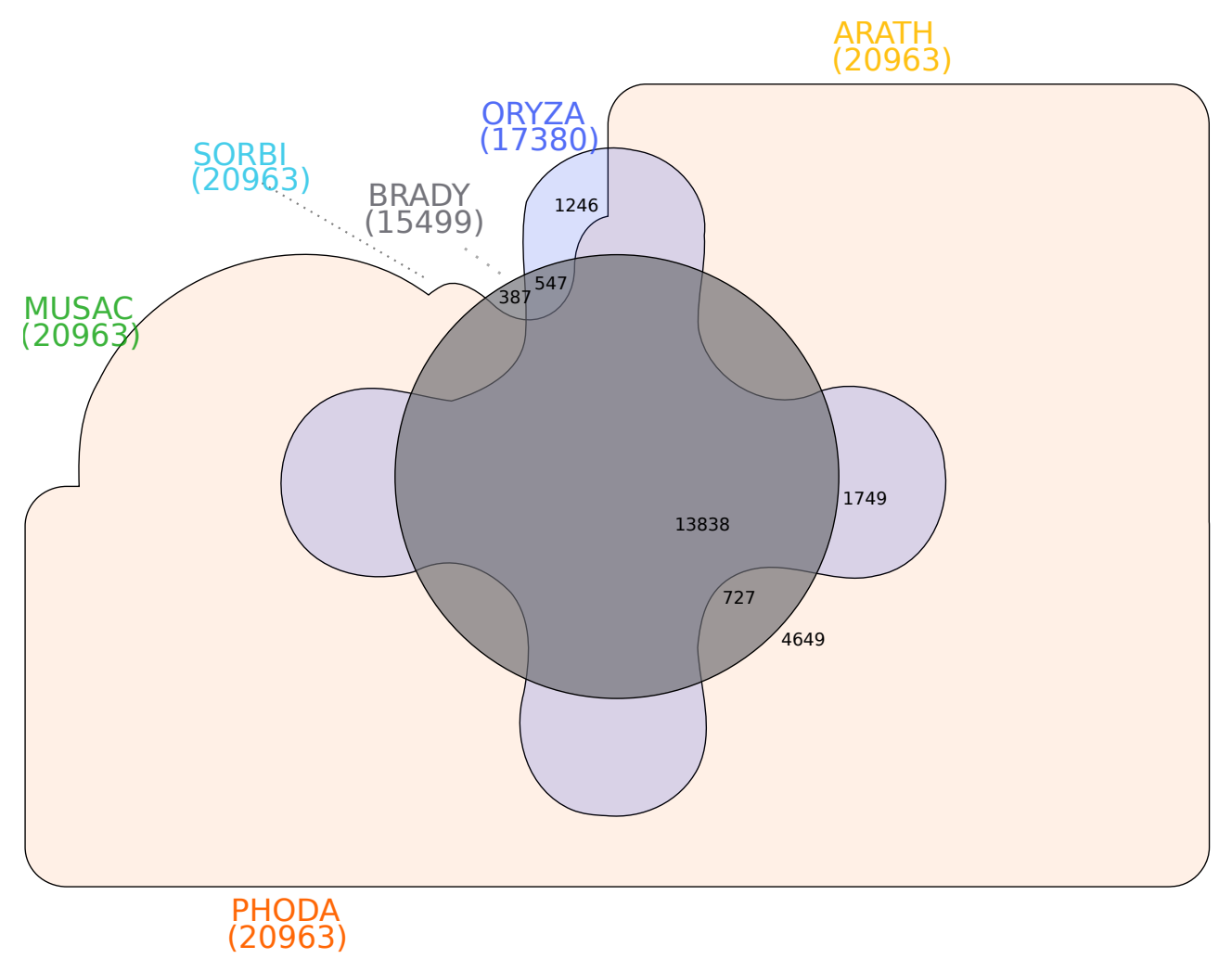

Nessa ferramenta, a técnica InteractiVenn foi implementada e as operações de união podem ser codificadas de duas maneiras: por meio de uma lista de códigos (a chamada versão slider), que representam um diagrama para cada código, e por meio de uma codificação das operações em forma de árvore binária (motivada pela árvore presente em (D'HONT et al., 2012)), em que cada bifurcação da árvore representa uma operação de união sobre os nós inferiores à ela.

Sendo assim, o usuário pode definir quais operações de união ele quer representar. No decorrer de sua análise, o usuário pode adicionar operações de união, ou removê-las, e formar uma lista de diagramas que ele achou interessante. Por exemplo, se ele criou os diagramas 1, 2, 3, 4 e 5, mas apenas os diagramas 3 e 5 realmente expressaram informações importantes, ele pode manter no slider apenas os códigos que derivaram os diagramas 3 e 5 e navegar por esses diagramas, hora exibindo o diagrama 3 na tela, hora exibindo o diagrama 5 . 
Figura 24 - Tela principal do InteractiVenn website (<http://www.interactivenn.net $>$ ). À esquerda fica o diagrama com que o usuário pode interagir para verificar os elementos de cada intersecção, clicando nos respectivos números, por meio de pop-ups. À direita ficam os campos de entrada dos conjuntos bem como a definição de quantos conjuntos serão visualizados. Acima do diagrama fica o campo onde o usuário digita o código que define a sequência de operações de união.

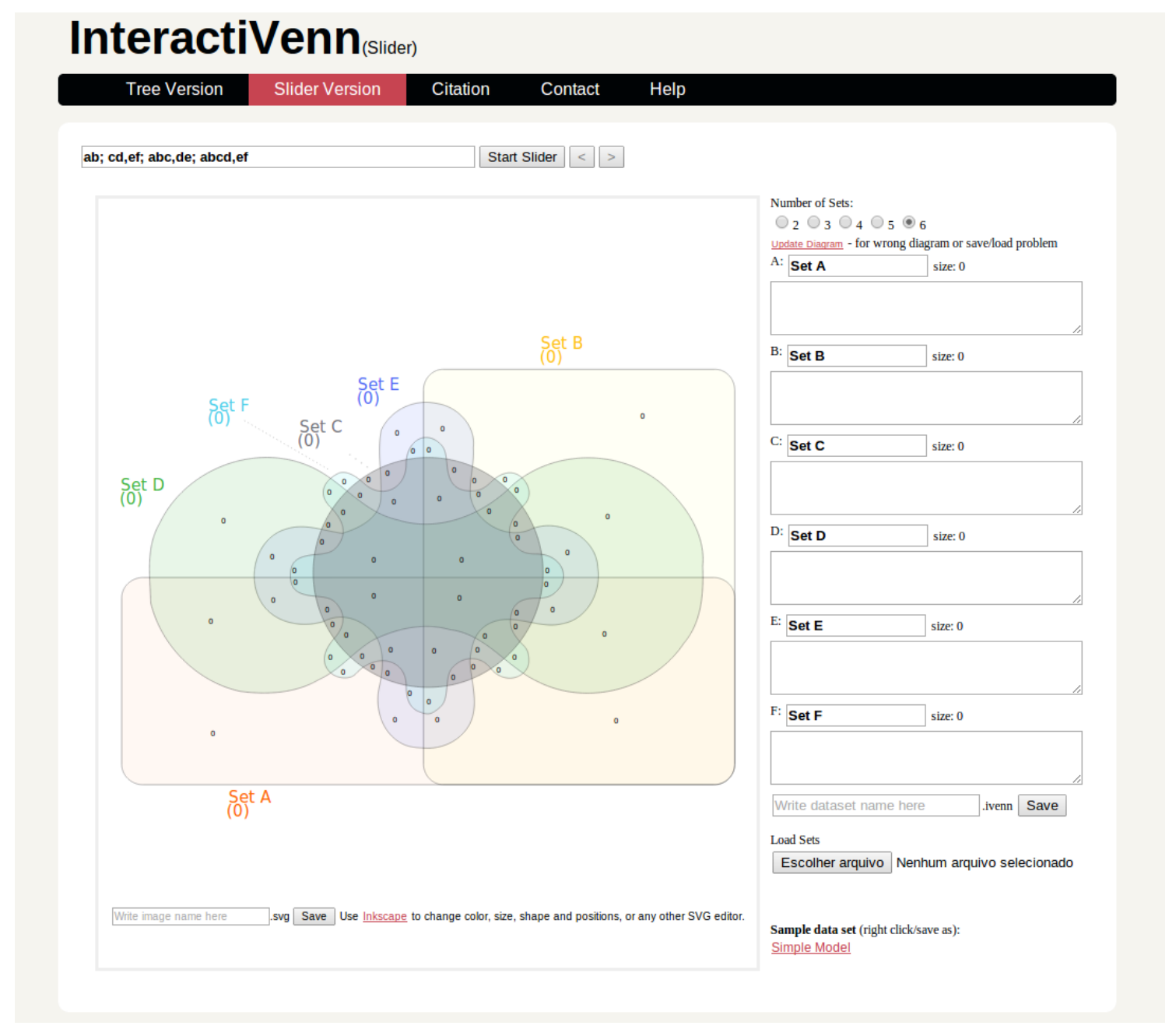

Há também a função de exportação de diagramas em formato SVG (Scalable Vector Graphics) (W3C, 2001) e de exportação dos conjuntos listados em um formato próprio e descrito no website. Com isso o usuário pode deixar disponíveis para consulta ambos os arquivos e também o código de operações de união que utilizou em seu próprio website ou por meio de outra forma de compartilhamento.

A codificação por árvore binária foi motivada pela árvore apresentada no trabalho de D’Hont et al. (2012). Com a árvore, o usuário pode explorar e executar operações de união seguindo a hierarquia que ela representa. É uma abordagem diferente da abordagem via slider, em que o usuário constrói listas de operações de união. No caso da árvore, é mais difícil pensar em como ela deveria ser para que determinadas operações de união aconteçam sobre determinados conjuntos em determinado nível. A árvore binária, portanto, 
é indicada apenas para casos em que ela já existe para os conjuntos explorados, como é o caso do artigo mencionado.

Para apresentar a ferramenta construída, utilizou-se o mesmo conjunto de dados do artigo, exemplificando a utilização do slider e da árvore binária. Na Figura 25 é apresentado o diagrama construído com cada conjunto original. A partir desse diagrama, pode-se seguir uma das abordagens: operações de união explicitamente definidas (slider) ou implicitamente definidas (árvore binária). Ambas as codificações estão documentadas no website da ferramenta.

Figura 25 - Representação dos mesmos conjuntos da Figura 21 por meio da ferramenta web InteractiVenn.

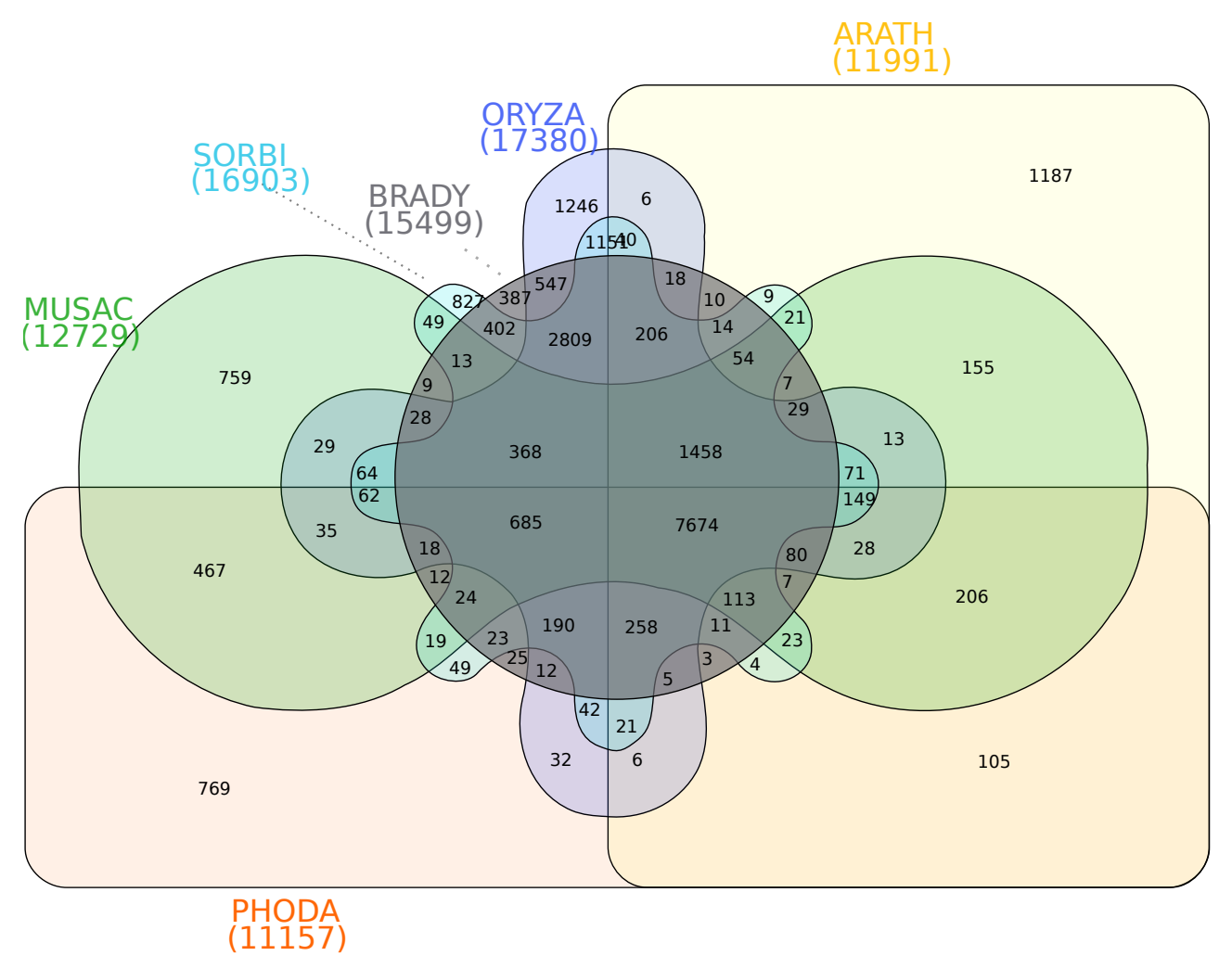

Considerando apenas as plantas exibidas no diagrama da Figura 21 e a árvore da Figura 22, construiu-se uma árvore menor que é definida por hierarquia de parênteses da seguinte maneira: (Arabidopsis thaliana, ((Musa acuminata, Phoenix dactylifera), (Sorghum bicolor, (Oryza sativa, Brachypodium distachyon)))). A representação visual desta árvore é exibida na Figura 26.

$\mathrm{Na}$ ferramenta web, o usuário entra com os dados e cada conjunto passa a ser identificado por uma letra, sendo o primeiro conjunto representado pela letra "a" e o último (se houver seis) representado pela letra "f". Essas letras são utilizadas para codificar as operações de união. No exemplo em questão, então, a codificação da árvore é $(B,((D, A),(F,(E, C))))$. Os nomes das espécies foram abreviados e a identificação está relacionada como segue: 
Figura 26 - Representação resumida da árvore binária da Figura 22. Nesta, apenas as seis espécies que aparecem no diagrama da Figura 21 foram consideradas. Essa estrutura representa visualmente a árvore que serviu de codificação para a execução de operações de união pelo InteractiVenn website com o conjunto de dados relacionado à Musa acuminata.

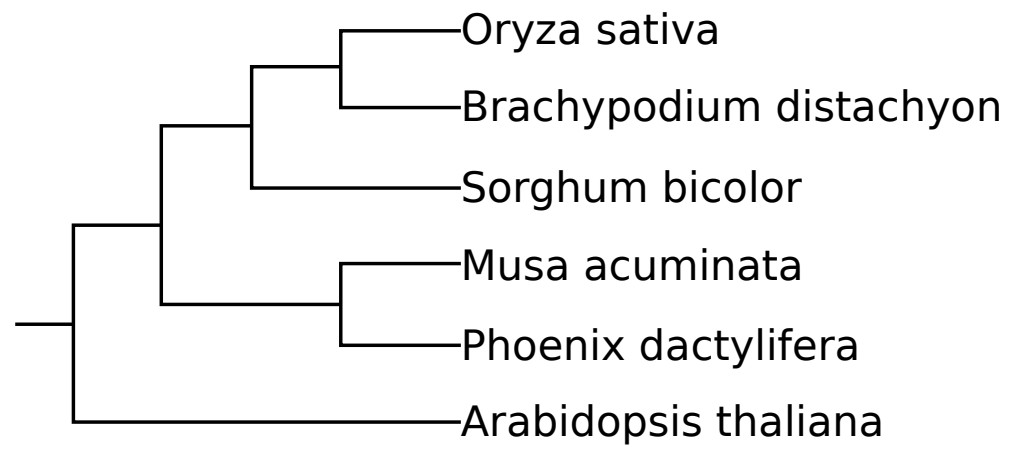

a) A: Phoenix dactylifera (PHODA);

b) B: Arabidopsis thaliana (ARATH);

c) C: Brachypodium distachyon (BRADY);

d) D: Musa acuminata (MUSAC);

e) E: Oryza sativa (ORYZA);

f) F: Sorghum bicolor (SORBI).

Cada nível da árvore representa um diagrama formado por operações de união. O usuário navega por esses níveis, a fim de visualizar um diagrama ou outro, saindo do diagrama com o maior número de conjuntos unidos para o diagrama sem nenhuma união realizada. Os códigos apresentados a seguir dizem respeito aos níveis da árvore da Figura 26. Cada nível é indicado pelos parênteses em negrito e pelos conjuntos sublinhados. Todos os conjuntos entre parênteses em negrito estão sendo unidos naquele nível. Os níveis da árvore seguem a ordem inversa do parentesamento utilizado na matemática, isto é, primeiramente são considerados os parênteses mais externos, até se chegar aos mais internos. No último nível, nenhum parêntese é considerado.

a) $(\underline{\mathrm{B},((\mathrm{D}, \mathrm{A}),(\mathrm{F},(\mathrm{E}, \mathrm{C}))))})$ união de todos os conjuntos;

b) $(\mathrm{B},((\mathrm{D}, \mathrm{A}),(\mathrm{F},(\mathrm{E}, \mathrm{C}))))$ : união de todos os conjuntos, exceto o conjunto B.

c) $(\mathrm{B},((\underline{\mathrm{D}, \mathrm{A}}),(\underline{\mathrm{F},(\mathrm{E}, \mathrm{C})})))$ : união entre $\mathrm{D}$ e A e também união entre $\mathrm{F}, \mathrm{E}$ e C;

d) $(\mathrm{B},((\mathrm{D}, \mathrm{A}),(\mathrm{F},(\underline{\mathrm{E}, \mathrm{C}}))))$ : união apenas entre $\mathrm{E}$ e $\mathrm{C}$;

e) $(\mathrm{B},((\mathrm{D}, \mathrm{A}),(\mathrm{F},(\mathrm{E}, \mathrm{C}))))$ : nenhuma operação de união, diagrama sem modificações.

Outra maneira de codificar essa mesma sequência de operações de união é por meio da codificação pela versão slider. Nela, o código da árvore é traduzido para $B D A F E C$; $D A F E C$; DA, FEC; EC; . Cada elemento dessa expressão é separado por ponto e vírgula (;) 
e representa as operações de união de um diagrama (de um nível da árvore). O último nível da árvore, em que não há operações de união, é representado pela ausência de código após o último ponto e vírgula. Essa forma de representar operações de união é mais intuitiva. Porém, o usuário pode cometer enganos ao tentar reproduzir as mesmas operações que a versão de árvore binária produziria.

O nível em que todas as monocotiledôneas são unidas e comparadas à planta modelo Arabidopsis thaliana é representado na Figura 27. Neste diagrama, pode-se perceber que apenas $10 \%$ dos genes desta planta são exclusivos da mesma, ou que $90 \%$ deles foram encontrados em plantas monocotiledôneas, indicando um nível de semelhança genética.

Figura 27 - Diagrama de comparação entre monocotiledôneas e Arabidopsis thaliana em um diagrama de seis conjuntos transformado em um diagrama de dois conjuntos. Todas as monocotiledôneas foram unidas para destacar suas diferenças e semelhanças em relação à Arabidopsis thaliana

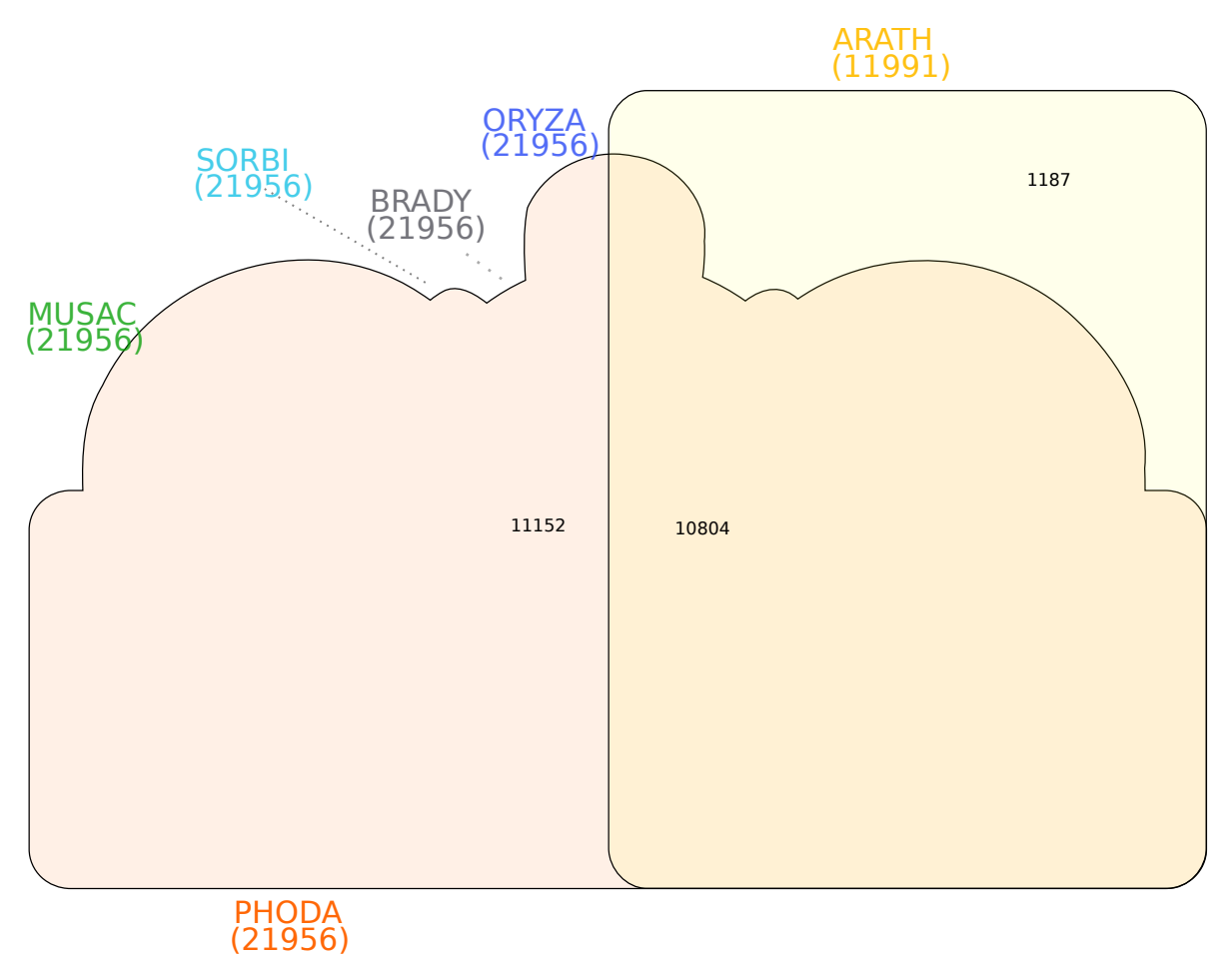

Essa e outros tipos de comparações podem ser feitas utilizando a ferramenta web e os diagramas de Venn. No entanto, a ferramenta não permite a comparação de redes. Para isso, este trabalho teve ainda como objetivo a criação de uma ferramenta que permitisse tal tipo de análise, envolvendo redes e conjuntos extraídos delas. Na seção 3.2 um caso simples é exemplificado e, em seguida, a ferramenta é detalhada.

\subsection{Análise comparativa de redes biomoleculares}

Apesar das características das redes poderem ser vistas como conjuntos, elas estão inseridas em um contexto de interações e juntas fazem parte dos sistemas biológicos. 
Considerar as características em forma de conjuntos e relacioná-las às respectivas redes permite uma análise mais completa e, ao mesmo tempo, facilita a atividade de exploração.

Quando se quer comparar redes e suas características, é comum aplicar operações de união e intersecção entre nós das redes ou mesmo procurar por nós exclusivos. Quando uma operação de intersecção é utilizada entre duas redes, restam apenas os vértices e arestas que existem em ambas. Se uma operação de união é aplicada, uma rede geral com todos os vértices e todas as arestas das redes é criada. Já quando se trata de uma operação de vértices exclusivos das redes, uma rede com vértices e arestas de ambas será criada; porém, esta rede não possui os vértices e arestas comuns entre duas ou mais redes originais; seus vértices, portanto, só aparecem em uma das redes. Cada rede resultante desse tipo de operação é referenciada pela expressão rede final nesta dissertação.

Para exemplificar o funcionamento desse processo de operações de conjuntos sobre redes, utilizou-se o exemplo da coloração de pulgões descrito na subseção 2.1.1 e ilustrado na Figura 1. Nela, há duas vias metabólicas, uma completa e uma incompleta, que estão representadas em forma de grafo na Figura 28 vista a seguir. Na Figura 28(a) é apresentada a rede da via completa, de um pulgão verde. Na Figura 28(b), o pulgão é transparente, devido à ausência da enzima $A$. O gene que gera a enzima $A$ não está corretamente codificado no DNA deste pulgão, faltam ativadores da enzima ou há outro fator que impede a transformação do pigmento transparente em pigmento rosa.

Ao realizar a operação de intersecção entre as redes das Figuras 28(a) e 28(b), a rede final é a mesma da Figura 28(b). Ao executar a união, o resultado é a rede da Figura 28(a). Já quando é aplicada uma operação para identificar os itens exclusivos, o resultado é a rede apresentada na Figura 28(c).

Apesar do processo de união e intersecção sobre os elementos das redes apresentarem resultados iguais às próprias redes originais, quando os atributos e seus valores são considerados, elas se tornam diferentes. Por exemplo, no processo de união entre as duas redes, em que também se faça a união de valores de atributos, a enzima $B$ que tem um atributo chamado "ativado" conterá ambos os valores "verdadeiro" e "falso", indicando que hora essa enzima esteve ativada (via completa) e hora inativada (via incompleta).

Atributos como esse foram denominados nesta dissertação de atributos multivalorados, por conterem mais de um valor. Em biologia esse tipo de atributo é muito comum, devido às moléculas terem diversas funções, serem movidas a diversas partições celulares, entre outras características que se tornam multivaloradas.

Duas aplicações de diagramas de Venn neste exemplo são apresentadas na Figura 29. Na primeira, Figura 29(a), criou-se um diagrama que compara o atributo "ativado" entre as redes, dado que foram utilizadas todas as enzimas para a construção dos conjuntos de valores. Neste caso, o conjunto da rede da via completa contém apenas o valor "verdadeiro" 
Figura 28 - Modelagem em redes das vias completa e incompleta de pigmentação de pulgões e da operação de exclusivos sobre ambas. Em (a), é representada a via completa de pigmentação do pulgão, em que o pigmento transparente é convertido em pigmento rosa pela enzima $A$, que posteriormente é convertido em pigmento verde pela enzima $B$. A ausência da enzima $A$ implica que o pulgão seja transparente, pois a via está incompleta ((b)). Ao aplicar a operação de exclusivos sobre as redes, identificou-se a origem do problema que diferencia a via completa da incompleta: a existência dos pigmentos rosa e verde e a existência da enzima $A$.

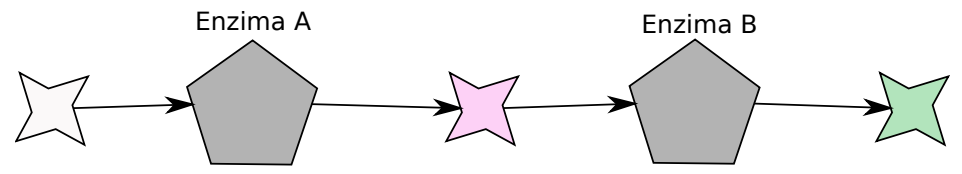

(a) Via completa

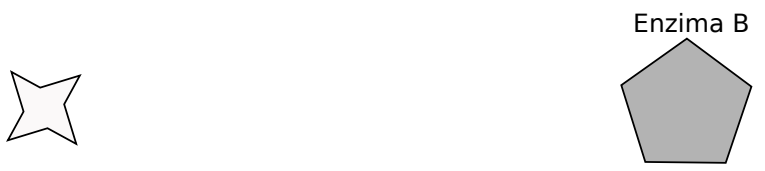

(b) Via incompleta
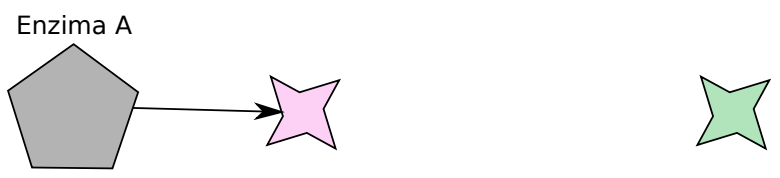

(c) Elementos exclusivos

como elemento. Já o conjunto da via incompleta contém apenas o valor "falso". Pelo diagrama, percebe-se que não há nenhuma semelhança entre as vias com relação a este atributo.

No caso de um atributo que representasse a partição celular na qual tais enzimas são encontradas, muitos valores poderiam estar associados. Dessa forma, o diagrama poderia apresentar o conjunto \{núcleo, citoplasma\} como intersecção, o conjunto \{membrana plasmática\} como exclusivo da via completa e o conjunto $\emptyset$ como exclusivo da via incompleta. Isto poderia indicar que as interações da via incompleta, se houvesse, ocorreriam onde ocorrem as da via completa.

Na segunda aplicação, Figura 29(b), criou-se um diagrama que compara os valores do atributo "ativado", de tal forma que os conjuntos são identificados pelos valores e seus elementos são as enzimas às quais esses valores estão atribuídos. Sendo assim, para o conjunto "verdadeiro", tem-se como elementos as enzimas A e B. Já para o conjunto "falso", tem-se apenas a enzima $B$. Este diagrama permite que se faça uma separação dos vértices de acordo com seus valores. Neste caso, identificou-se que apenas a enzima $B$ possui alteração de valores, pois é ela que está na região de intersecção do diagrama.

Ambos os diagramas podem ser feitos a partir das redes, no entanto, de maneiras 
Figura 29 - Comparação de dois tipos de geração de diagramas de Venn por meio de atributos de redes. Em (a), o diagrama é construído por meio do atributo "ativado", recuperando as informações das redes originais (rede da via completa e rede da via incompleta). Em (b), o diagrama é construído por meio da rede final, criada a partir da união entre as redes originais. Cada conjunto, nessa versão, representa um valor do atributo "ativado". Os elementos desses conjuntos são identificadores vértices da rede final. Se um vértice possui um determinado valor, ele será associado ao conjunto que representa este valor.

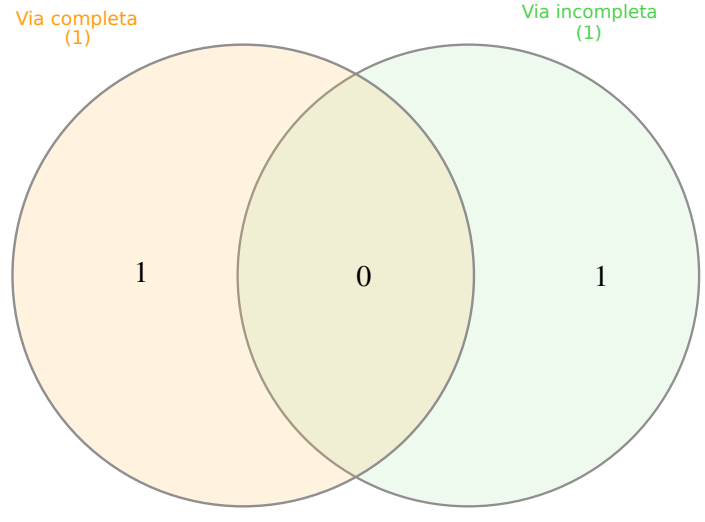

(a) Diagrama pelo atributo "ativado"

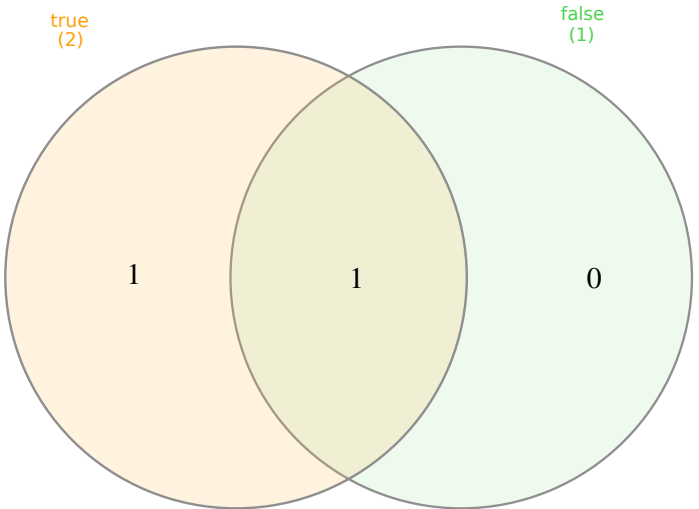

(b) Diagrama por valores do atributo "ativado"

diferentes. No primeiro caso, diagrama por atributo ou baseado em redes, utiliza-se as redes originais para a construção do mesmo, pois está se comparando os valores de um atributo das redes em relação a elas mesmas. No segundo caso, diagrama por valor, é necessária a utilização de uma rede final. No exemplo apresentado, portanto, utilizou-se a rede final formada pela união dos vértices e arestas e também pela união de seus atributos. Utilizar a rede final permite que outras configurações possam ser testadas. Por exemplo, ao invés de utilizar uma rede formada pela união de atributos, pode-se utilizar uma rede em que se faça a intersecção deles. Esse tipo de diagrama não compara as redes, mas avalia a distribuição dos vértices dados valores selecionados, e, ao contrário do primeiro caso, não necessita das informações das redes originais.

Nas subseções seguintes são apresentadas as técnicas adotadas para que a análise desse tipo de dado pudesse ser feita de maneira visual. Primeiramente são apresentadas a ferramenta VisPipeline-MultiNetwork e o pipeline de visualização criado, que é uma sequência de atividades realizadas até que se chegue à etapa final, onde o usuário analisa visualmente seus dados. Em seguida, são descritas as atividades que acontecem neste pipeline, como a etapa de posicionamento dos vértices para o desenho da rede. Por fim, são apresentadas as funcionalidades da etapa de interação e visualização, que envolvem as soluções adotadas para a representação de atributos multivalorados e para a análise de conjuntos contidos nas redes. 


\subsubsection{VisPipeline-MultiNetwork e o pipeline de visualização}

No laboratório VICG, grande parte dos projetos atuais são desenvolvidos em uma plataforma de visualização genérica, escrita em Java, e baseada em componentes e na reutilização das técnicas já desenvolvidas pelo grupo. O sistema foi originalmente nomeado VisPipeline, e suas funções de visualização estão relacionadas principalmente à projeção de dados multidimensionais no espaço de duas e três dimensões.

Outras versões do VisPipeline surgiram, cada uma com uma especialidade. Um exemplo é o VisPipeline-Graph (MARTINS et al., 2012) e, agora, o VisPipeline-MultiNetwork, produto deste trabalho e extensão do VisPipeline-Graph.

O VisPipeline-Graph é um sistema adaptado para a visualização de redes e testado com redes sociais. Já o VisPipeline-MultiNetwork, foi desenvolvido para atender as necessidades de análise como descritas no início da seção 3.2. Uma vez que os sistemas para a visualização de redes biológicas, como o Cytoscape e o Gephi, não atendem às necessidades que envolvem operações sobre redes considerando atributos e a existência de atributos multivalorados.

Todas as versões do VisPipeline partem do princípio da execução de um pipeline. Um pipeline é uma sequência de operações realizadas para se chegar a um objetivo. Por exemplo, a seguinte sequência é um pipeline básico de visualização: carregamento dos dados, pré-processamento, processamento e, por fim, a representação visual. No VisPipeline, cada uma destas etapas se torna um componente. Esses componentes, então, são conectados uns aos outros, de maneira que o resultado de um componente possa servir como entrada para outro componente.

Neste trabalho, criou-se um pipeline de visualização exibido na Figura 30 e definido como: leitura das redes; filtro numérico sobre os nós; operação de conjuntos sobre as redes resultando em uma rede final; posicionamento dos nós da rede final no plano de duas dimensões; representação gráfica com interações e funções como criação de diagramas de Venn. Cada retângulo da Figura 30 se refere a uma etapa do pipeline. Elas estão conectadas e a execução do pipeline obedece a ordem: do componente mais superior (MultiNetwork Reader) ao mais inferior (MultiNetwork View Frame).

O pipeline criado foi projetado com a colaboração de biólogos do LNBio. Ele atente os requisitos para que seja possível comparar redes biomoleculares e trabalhar com atributos multivalorados.

Seu primeiro componente é o MultiNetwork Reader (Figura 30(a)). Nele, o usuário identifica a localização das redes que serão lidas em formato XGMML (eXtensible Graph Markup and Modeling Language) (PUNIN; KRISHNAMOORTHY, 2001). Neste arquivo, valores de atributos multivalorados devem estar separados por ";" (ponto e vírgula). A janela de interação que é aberta ao executar este componente é exibida na 
Figura 31.

Figura 30 - Pipeline de visualização do VisPipeline-Multinetwork. Cada componente é responsável por um tipo de processamento, como segue: (a) MultiNetwork Reader: leitura de redes no formato XGMML; (b) MultiNetwork Filter: remoção de nós (e conexões associadas) que atendem a uma condição; (c) MultiNetwork Operations: operação de intersecção, união ou exclusividade sobre nós e atributos; (d) Attribute Projection Layout: cálculo de distância entre nós baseando-se em atributos escolhidos; (e) Interactive Document Map (IDMAP): posicionamento dos nós no plano 2D dada uma matriz de distâncias; (f) MultiNetworkModel: criação de um modelo com informações visuais da rede, incluindo posicionamento dos nós, cores, tamanhos, entre outros atributos, além de conter dados originais das redes; (g) MultiNetworkViewFrame: criação de uma janela de interação com o usuário e exibição da rede. As conexões entre componentes indicam o fluxo dos dados, dependências e sequências de execução.

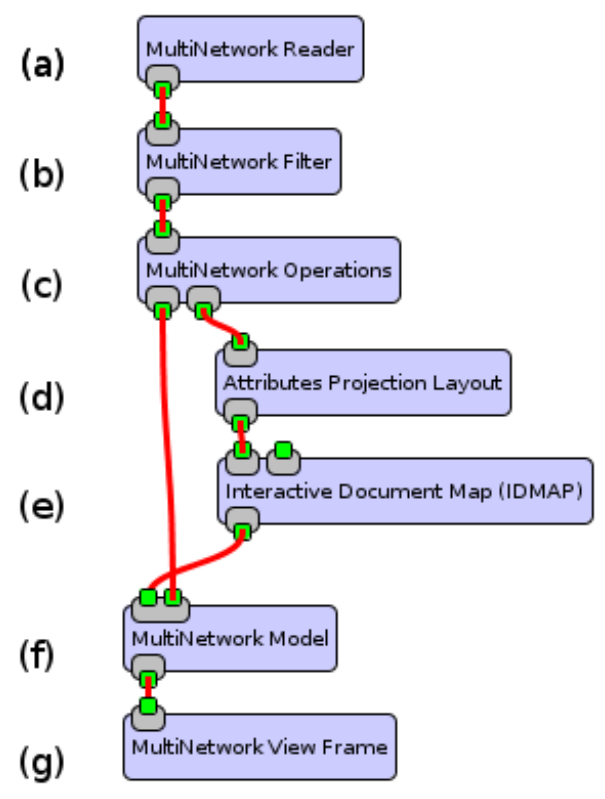

Depois de ler as redes, um filtro numérico é aplicado sobre elas pelo componente MultiNetwork Filter (Figura 30(b)). Esse filtro é opcional e pode haver mais de um. O usuário pode remover este componente e ligar o MultiNetwork Reader diretamente ao MultiNetwork Operations ou adicionar mais componentes do tipo MultiNetwork Filter, um conectado após o outro, a fim de realizar mais de um filtro. Cada componente realiza a remoção de nós que atendem a um requisito para um determinado atributo. Por exemplo, o atributo "expressão" pode ser utilizado para remover proteínas cujo valor para esse atributo seja menor que $K$. Consequentemente as conexões destas proteínas removidas também são removidas. A janela de interação pode ser vista na Figura 32.

Em seguida, as redes são utilizadas para produzir uma rede final por meio de uma das seguintes operações sobre os vértices e arestas ou sobre os atributos: união, intersecção ou exclusivos. O componente que realiza tal tarefa é o MultiNetwork Operations 
Figura 31 - Janela de entrada das redes no VisPipeline-MultiNetwork. O usuário pode entrar com até seis redes no formato XGMML. Esta janela está implementada no componente MultiNetwork Reader.

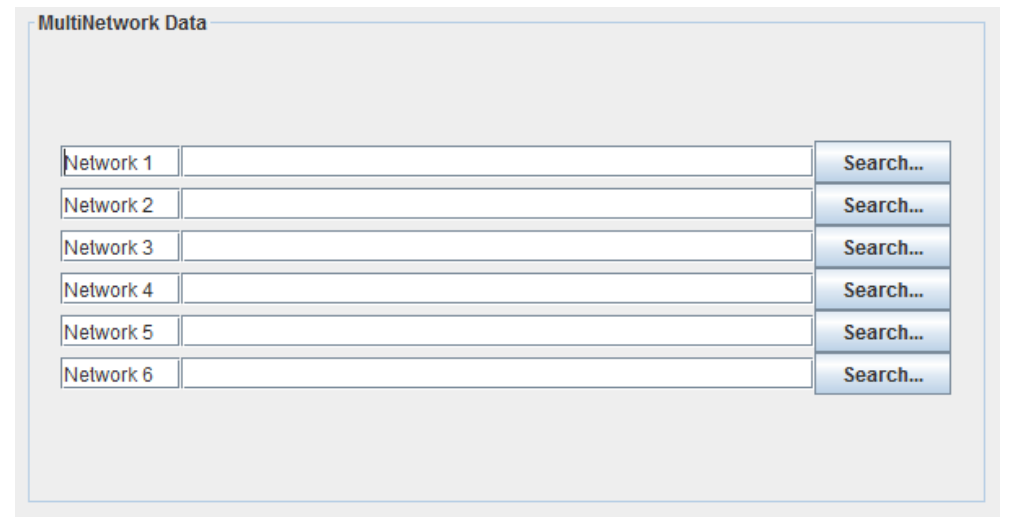

Figura 32 - Janela de entrada dos parâmetros do componente MultiNetwork Filter. O usuário seleciona um atributo numérico, um operador lógico e entra com o valor com a qual o operador lógico será combinado para remover vértices que satisfazem tal condição.

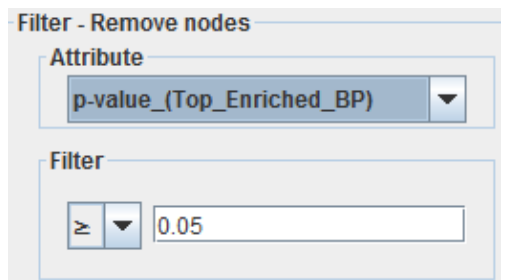

(Figura 30(c)), e a janela de interação pode ser vista na Figura 33. Neste componente o usuário define qual operação será aplicada sobre os vértices e qual operação deve ser aplicada sobre os atributos. Se nenhuma operação for escolhida para os atributos (opção None no componente), a primeira rede é escolhida para o preenchimento dos atributos da rede final.

A rede final construída é a que será visualizada no fim do pipeline em forma de desenho de vértices e arestas. Para isso, é necessário calcular qual será a posição de cada um dos vértices. Essa é a função do componente Interactive Document Map (IDMAP) (Figura 30(e)). Este componente realiza uma projeção num espaço de duas dimensões partido de uma matriz de similaridades. Outras técnicas de projeção podem ser utilizadas, porém a IDMAP apresentou bons resultados para os testes realizados neste trabalho. Durante a visualização, o desenho do grafo baseado em algoritmo de forças pode ser executado, caso esse tipo de projeção não seja de interesse. Mais sobre posicionamento dos vértices pode ser visto na subseção 3.2.1.1.

O cálculo da matriz de similaridades entre vértices é realizado num passo anterior pelo componente Attributes Projection Layout, Figura 30(d). A janela de interação deste componente é exibida na Figura 34. Nesta janela o usuário seleciona quais atributos 
Figura 33 - Janela de entrada dos parâmetros do componente MultiNetwork Operations. O usuário seleciona qual será a operação realizada sobre os nós da rede no primeiro item. No segundo item, o usuário seleciona a operação que será feita sobre os atributos das redes.

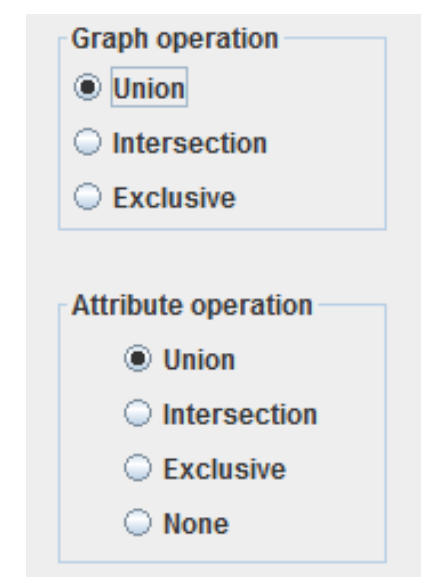

presentes na rede final devem ser considerados para calcular a similaridade entre os vértices. Essa similaridade é calculada considerando que cada atributo para cada vértice é um conjunto de valores, pois, mesmo que um atributo seja numérico originalmente, ele passa a ser um atributo multivalorado após as operações de conjunto sobre os atributos.

Figura 34 - Janela do componente Attributes Projection Layout para a seleção dos atributos que serão considerados no cálculo da similaridade entre os vértices da rede final que este componente realiza.

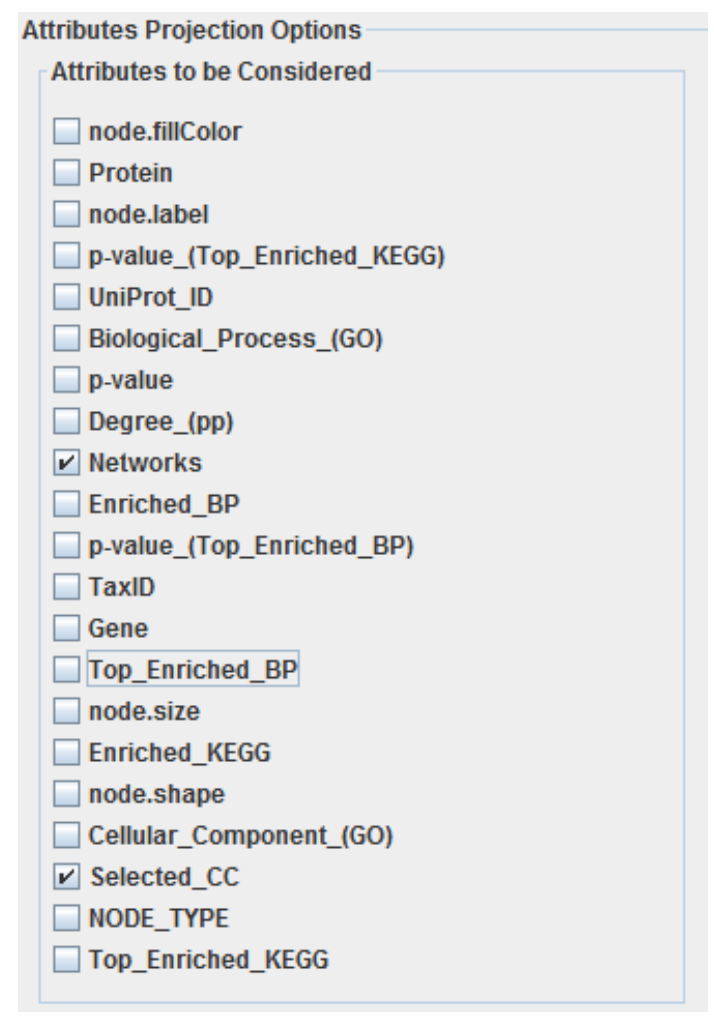

Com isso, definiu-se que a similaridade entre dois vértices é a soma da similaridade 
deles para cada atributo selecionado no componente Attributes Projection Layout. Cada similaridade para cada atributo de cada par de vértices é calculada pela cardinalidade da intersecção dos valores desse atributo nesses dois vértices dividida pela cardinalidade da união desses valores. Se dois conjuntos são iguais, a intersecção é igual à união e, portanto, a divisão das cardinalidades será igual a 1. Caso os dois conjuntos sejam completamente diferentes, a divisão terá valor igual a 0 , pois a cardinalidade da intersecção será igual a 0 . Esse cálculo também é conhecido como coeficiente de similaridade de Jaccard (XIAO et al., 2009).

Essa similaridade é calculada para todos os possíveis pares de vértices, resultando em uma matriz de similaridades. Essa matriz é, então, enviada para o componente Interactive Document Map (IDMAP), onde será calculada a posição de cada vértice. Feito isso, esses valores de posicionamento são unidos aos resultados do componente MultiNetwork Operations, além de outras estruturas serem criadas, relacionando a rede final, o posicionamento dos vértices e as redes originais. Esses elementos são unidos pelo componente MultiNetwork Model (Figura 30(f)), um componente que serve como um pré-processamento para a fase de layout.

O último componente é o MultiNetwork View Frame (Figura 30(g)). Este componente é responsável por exibir a janela que permite a visualização e interação do usuário. A janela com um exemplo de rede pode ser vista na Figura 35.

Figura 35 - Janela final do pipeline de visualização. Nela, o usuário pode mover, selecionar e remover vértices e suas arestas, criar diagramas de Venn, entre outras funcionalidades que podem ser utilizadas no processo de visualização.

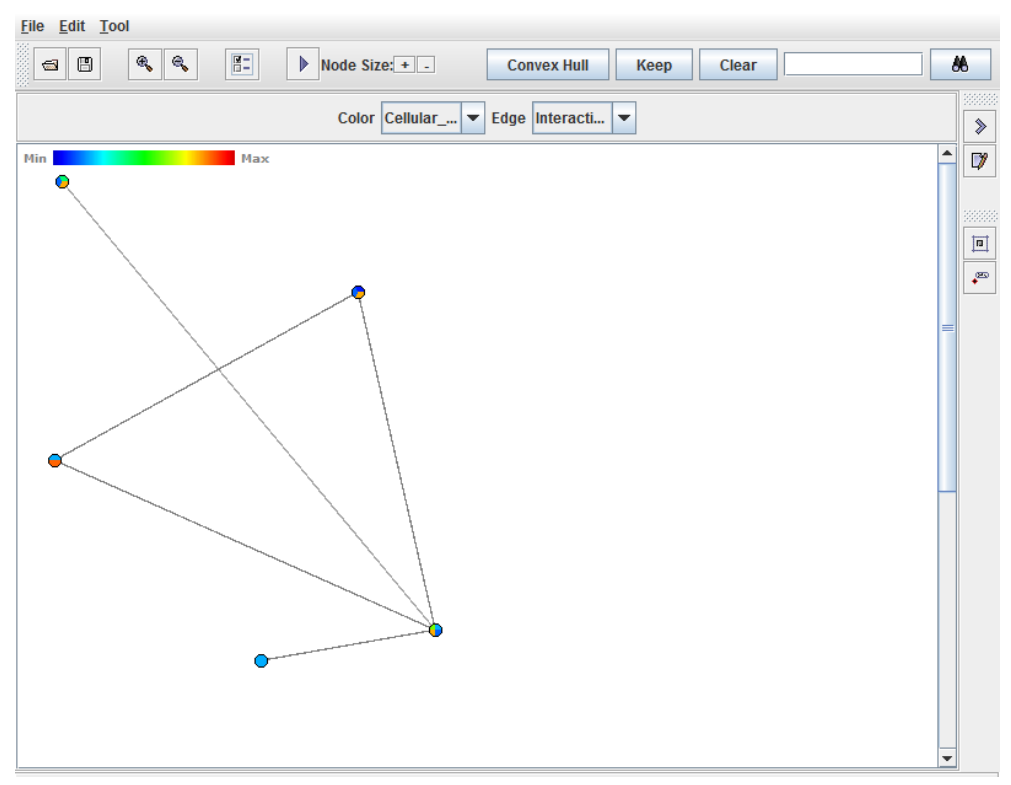

Na janela de interação é possível selecionar vértices, modificar qual atributo as cores dos vértices estão representando, criar diagramas de Venn a partir da rede final ou das redes originais considerando vértices selecionados na rede final, entre outras interações 
possíveis.

Nas próximas seções são explicadas em mais detalhes os principais processos do pipeline de visualização criado neste trabalho. A subseção 3.2.1.1 trata sobre a técnica de posicionamento utilizada no trabalho e a exemplifica, discutindo características da mesma. Na subseção 3.2.1.2 são descritas funcionalidades criadas para auxiliar a visualização das redes em específico, como a coloração dos vértices a partir de atributos multivalorados. Já na subseção 3.2.1.3, é apresentado como foi embutida no VisPipeline-MultiNetwork a técnica InteractiVenn para que fosse possível a análise e comparação das redes.

\subsubsection{O posicionamento dos vértices}

No contexto biomolecular, o posicionamento dos vértices com base nos atributos da rede é útil em análises em que a localização ou função das moléculas são de grande importância. Isto é, posicionar os vértices tentando aproximar vértices que possuem funções em comum, ou que estão juntos em uma mesma partição celular, ou que estão juntos e também possuem a mesma função, aumenta o poder de expressão da ferramenta, na medida que o usuário localiza rapidamente elementos similares.

O posicionamento de vértices por similaridade de atributos pode ser feito como foi para a análise de redes sociais com o VisPipeline-Graph no trabalho de Martins et al. (2012). Tal abordagem parte da construção de uma matriz de distâncias e posterior utilização da técnica IDMAP. Esta técnica busca projetar os vértices em um plano de duas dimensões de tal forma que os mais similares fiquem próximos.

No VisPipeline-Graph, os componentes responsáveis pelo cálculo de similaridade baseado em atributos e pela IDMAP estão implementadas, porém, especializados para trabalhar com atributos numéricos, datas, e cadeias de caracteres. Para o caso do cálculo da similaridade entre nós, adaptou-se neste trabalho o componente Attribute Projection Layout para ele funcionar com atributos multivalorados. Optou-se pelo cálculo da similaridade entre dois vértices utilizando o coeficiente de Jaccard já explicado. A distância entre vértices, então, é definida pela subtração de tal coeficiente de 1. Quando mais de um atributo é considerado na similaridade, utiliza-se como similaridade a média dos coeficientes dos atributos. Busca-se, na técnica de projeção, preservar proporcionalmente as distâncias no plano, em relação às distâncias originais calculadas.

O significado da semelhança entre moléculas pode, então, ser definido na escolha de atributos por meio do componente Attribute Projection Layout. Por exemplo, uma semelhança pode ser definida pelo atributo processo biológico, ou pelo atributo componente celular, por ambos ou por qualquer outra combinação de outros atributos de interesse.

No componente MultiNetwork Operations, além das operações de conjuntos, um atributo chamado Networks é adicionado a cada vértice da rede final. Esse atributo 
indica a quais redes aquele vértice pertence. Por exemplo, um vértice $A$ de uma rede final possui valores "rede 1" e "rede 2" no atributo Networks, pois ele está presente em ambas as redes. Mas o suposto vértice $A$ não está presente na "rede 3", que também foi entrada para o componente MultiNetwork Operations. Dessa forma, sabe-se que das três redes, tal vértice da rede final participa de apenas duas. Esse atributo adicionado à rede final, serve como um histórico do vértice que está sendo analisado, indicando suas origens. Isso permite que se faça o desenho do grafo baseando-se na informação sobre a quais redes os vértices pertenciam, resultando em uma projeção que se assemelha a um diagrama de Venn. Voltando ao exemplo, os vértices que aparecem apenas na "rede 1" serão, por definição, idênticos, pois apenas este atributo está sendo considerado, e, com isso, aparecerão sobrepostos no plano. Ao mesmo tempo, serão um pouco parecidos com os vértices que vieram da "rede 1" e da "rede 2", e ficarão próximos a estes no plano. Por sua vez, os vértices que só aparecem na "rede 2" tendem a ficar distantes dos vértices que só aparecem na "rede 1".

Na Figura 36 é exibido o resultado da projeção por atributo Networks de três redes unidas. No componente MultiNetworkOperations foram escolhidas a união entre vértices e entre atributos. Vértices exclusivos de uma rede aparecem nas extremidades do desenho. Vértices que aparecem em todas as redes estão ao centro. Essas regiões correspondem às regiões de um diagrama de Venn de três conjuntos.

Figura 36 - Exemplo de projeção de rede baseada um único atributo. Em (a), é exibido o resultado da projeção pela IDMAP utilizando o atributo Networks. Em (b), é exibida a mesma projeção após uma rápida perturbação no posicionamento dos vértices utilizando um algoritmo baseado em forças. A técnica IDMAP sobrepõe vértices tidos como idênticos; a técnica baseada em forças foi utilizada para exibir tal fato.

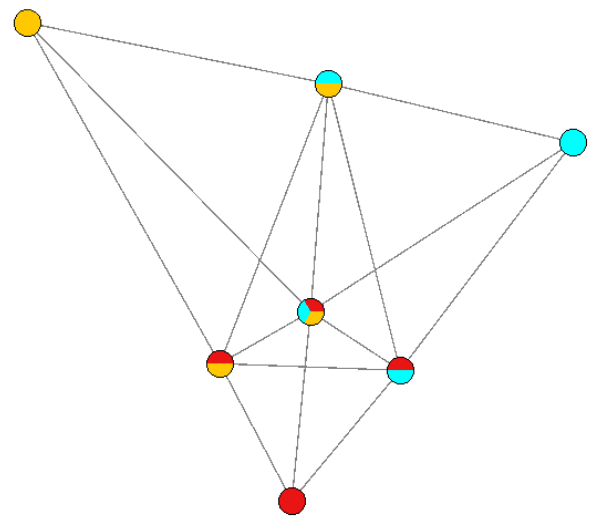

(a) Projeção por IDMAP.

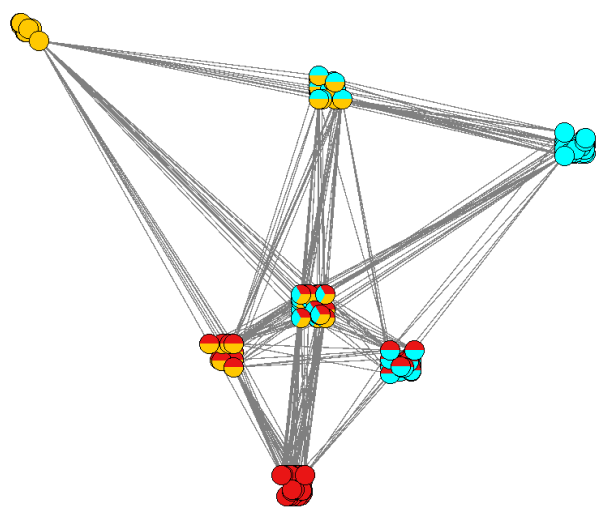

(b) Perturbação da projeção.

A abordagem utilizada para redes sociais no trabalho de Martins et al. (2012) se mostrou, portanto, eficiente para posicionar vértices cuja semelhança se baseia em conjuntos de valores, como é o caso do atributo Networks. No Capítulo 4, outras projeções baseadas em atributos são exibidas, utilizando dados biológicos, comprovando que a técnica utilizada 
neste trabalho satisfaz a necessidade do posicionamento pelas semelhanças construídas a partir da partição celular e dos processos biológicos de cada molécula.

Outra técnica disponibilizada no VisPipeline-MultiNetwork é a do posicionamento baseado em sistemas físicos de forças, como o algoritmo citado na subseção 2.3.2. Dessa forma, o usuário tem a opção de considerar apenas a topologia da rede para posicionar os vértices. Essa opção de posicionamento é aplicada na etapa de interação, se acionada pelo usuário.

No exemplo da Figura 36, a rede posicionada possui vértices cuja representação visual foi feita utilizando círculo com mais de uma cor. Cada cor indica que aquele vértice pertence a uma determinada rede. Essa e outras propriedades visuais do VisPipelineMultiNetwork são descritas na subseção 3.2.1.2.

\subsubsection{Representação visual de múltiplos valores e destaque de regiões}

Os múltiplos valores dos atributos das redes foram representados no layout por cores que preenchem um círculo dividido em $N$ partes, sendo $N$ o número de valores naquele vértice para determinado atributo. Cada uma dessas partes, então, é preenchida com uma cor. Assim, se um nó possui dois valores para um atributo que está sendo visualizado, este nó será metade de uma cor e metade de outra.

Um exemplo da representação visual pode ser visto na Figura 37. Cada valor de um atributo é associado a uma cor. Dessa forma, cada atributo possui um mapeamento único que relaciona valores do atributo e suas respectivas cores.

Figura 37 - Representação visual de multivalores em vértices. Cada cor representa um valor diferente associado aos vértices.

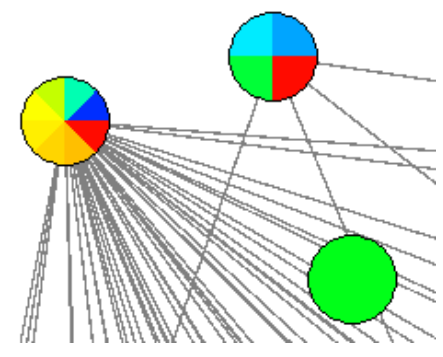

Tal abordagem possibilita a identificação de moléculas que possuem muitas funções, que estão em várias partes das células, que mantém sua função ao longo da vida da célula ou que variam sua função e em que intensidade. Essa representação também permite a identificação da origem dos vértices por meio do atributo Networks. Assim, se um vértice possui três cores para este atributo, ele existe em três redes.

O posicionamento de vértices apresentado na Figura 36 é, de certa forma, ideal, já que todos os vértices foram separados exatamente como se esperava. O algoritmo respeitou 
as similaridades calculadas entre vértices, não misturou, por exemplo, os vértices exclusivos da "rede 1" com vértices que aparecem na "rede 1" e na "rede 2 ".

Ao se utilizar dois atributos, os vértices acabam se distribuindo mais e a relação de proximidade por similaridade pode não ser mantida. De modo geral, nos testes realizados neste trabalho, o algoritmo apresentou bom desempenho. Alguns vértices foram mal posicionados, conforme descrição acima, enquanto a maioria se agrupava de maneira coerente (grupos de vértices de mesma(s) cor(es), indicando que os similares ficaram próximos).

A representação da informação por cores permite a busca visual por padrões ou por nós que apresentam certo valor, ou certa característica, como a quantidade de valores, entre outras. No entanto, há um problema quando se trata valores discretos como cores. Quando há muitos valores, alguns acabam sendo de cores muito parecidas, diferenciando-se na tonalidade e sendo, na verdade, da mesma cor na percepção do usuário. Quanto maior é o número de valores possíveis de um atributo, maior será a frequência deste problema.

Uma alternativa à busca visual, é realizá-la por meio do campo de busca. Nele, o usuário digita um texto, como "citoplasma", para identificar quais vértices possuem aquele valor. Esses vértices são selecionados e destacados automaticamente pela ferramenta e a partir dessa seleção outras funcionalidades podem ser aplicadas.

Para memorizar a seleção realizada, ou mesmo para destacar regiões de vértices que formam grupos, criou-se uma função que cria um polígono convexo a partir de vértices selecionados. O usuário seleciona os vértices que formarão o polígono por meio da ferramenta de seleção manual ou por meio do campo de busca e, então, aplica essa função denominada Convex Hull. Com isso, um polígono é criado ao fundo da projeção, auxiliando o usuário a memorizar o posicionamento de um grupo de vértices (ver Figura 38).

No exemplo da Figura 38, a rede foi posicionada pelas partições celulares e processos biológicos. Na Figura 38(a), os vértices cujos valores do atributo "partição celular" são iguais a "nucleus" (proteínas encontradas no núcleo da célula) são selecionados. A função Convex Hull foi aplicada, criando o polígono visto na imagem. Após essa seleção, o usuário poderia realizar outra, por exemplo, identificando vértices que estão no citoplasma e criar um novo polígono. Ambos os polígonos seriam mostrados ao usuário, permitindo comparar processos biológicos (cores dos vértices), dado que as proteínas estão no núcleo ou no citoplasma (polígonos que sombreiam os vértices).

Na Figura 38(b), utilizou-se a função Keep, que torna os vértices não selecionados invisíveis. Neste caso, as proteínas do núcleo permaneceram visíveis (exceto as mais à direita). O desenho da rede foi ampliado nesta parte e, então, buscou-se selecionar, por meio do campo de busca, alguns processos biológicos. Para cada processo biológico buscado, foi criado um polígono para identificar onde estão as suas respectivas proteínas. 
Figura 38 - Exemplo de utilização das funções Keep e Convex Hull sobre uma rede. A função Keep deixa visível apenas vértices selecionados. A função Convex Hull cria um polígono convexo que sombreia os vértices selecionados. Em (a), proteínas que estão no núcleo foram destacadas pelo polígono. Em (b), algumas destas proteínas foram mantidas visíveis. Utilizou-se a função Convex Hull para destacar proteínas de mesmo processo biológico.

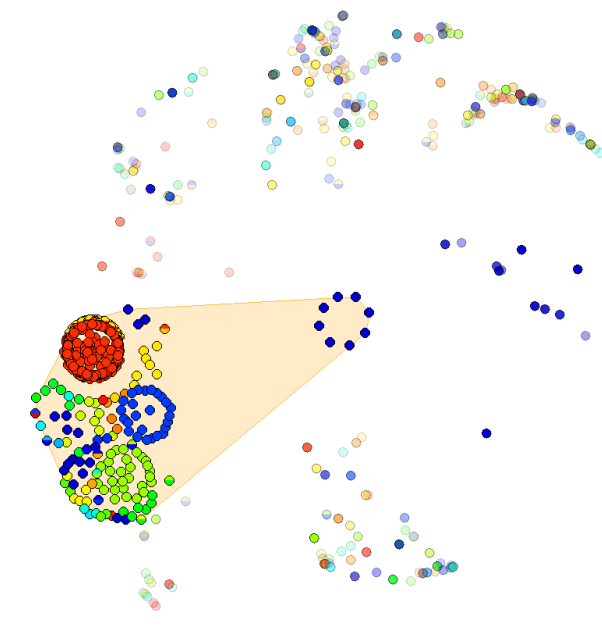

(a) Destaque de proteínas do núcleo.

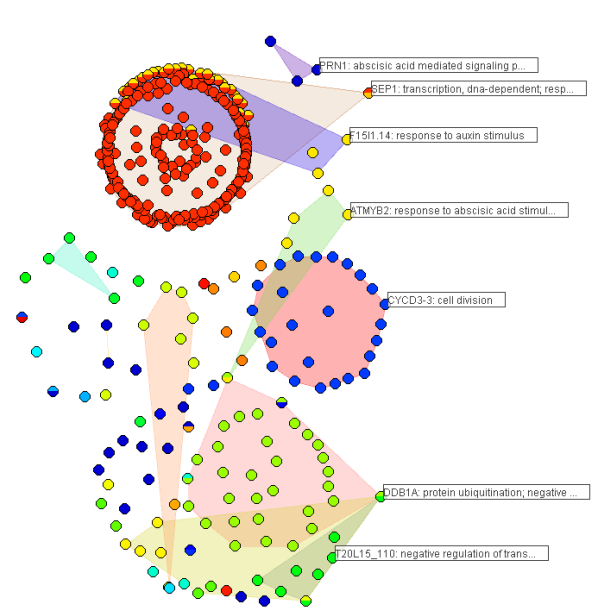

(b) Destaques de proteínas com mesmo processo biológico.

Outro exemplo é o uso da função Convex Hull sobre a rede da Figura 36. O resultado é um diagrama de Venn sob a rede, exibido na Figura 39. É possível identificar onde estão as intersecções entre os "conjuntos" tanto pela representação visual dos múltiplos valores como pelo desenho dos polígonos.

Figura 39 - Exemplo de projeção de rede baseada um único atributo, e destaque com polígonos convexos.

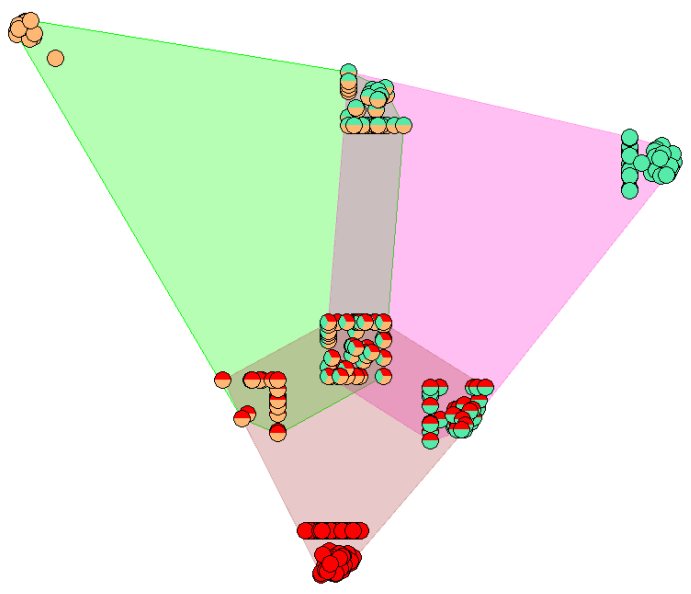

A técnica do desenho de polígonos se mostrou útil para o destaque de grupos de vértices para posterior análise. O usuário pode aplicar, por exemplo, o desenho de polígonos sobre vários grupos a partir de um atributo $A$ e, posteriormente, visualizar os vértices, colorindo-os de acordo com o atributo $B$. Dessa forma, dois atributos podem 
ser representados no desenho da rede ao mesmo tempo. Essa técnica é indicada apenas para quando o posicionamento reflete as similaridades de acordo com o atributo que se pretende utilizar para a construção dos polígonos.

Ainda para a análise e comparação dos valores dos atributos, integrou-se a técnica InteractiVenn $^{3}$ ao VisPipeline-MultiNetwork. Dessa forma, além do desenho dos vértices, arestas, da representação visual dos múltiplos valores e do desenho de polígonos, há também os diagramas de Venn interativos para apoiar a análise das redes biológicas. Tal funcionalidade é descrita na subseção 3.2.1.3.

\subsubsection{Integrando o InteractiVenn ao VisPipeline-MultiNetwork}

Para permitir uma visão global sobre os valores de um atributo escolhido, integrouse a utilização de diagramas de Venn ao VisPipeline-MultiNetwork, no componente MultiNetwork View Frame ${ }^{4}$ Cada rede gera um conjunto de respectivos valores para esse determinado atributo. Esses conjuntos são, então, utilizados para gerar um diagrama de Venn. Dessa forma, o diagrama permite a comparação de um atributo, demonstrando que valores esse atributo assume em cada uma das redes.

Outra funcionalidade implementada de construção de diagramas é a baseada em valores da rede final ${ }^{5}$. Nesta, o usuário pode escolher um atributo que contenha até seis valores. Cada valor será representado por um conjunto de genes que possuem os respectivos valores associados a eles. Por exemplo, se um vértice está representando uma proteína up-regulada em uma rede e down-regulada em outra rede, ao se criar uma rede pela união de vértices e união de atributos, o diagrama de Venn baseado nos valores "up" e "down" exibirá esse vértice na intersecção dos conjuntos "up" e "down", pois ele contém ambos os valores. Caso seja utilizada a união entre vértices e a intersecção entre atributos, o vértice em questão não estaria em nenhum dos dois conjuntos ("down" e "up"). A intersecção entre atributos torna o campo deste atributo vazio nesse vértice.

Há, portanto, duas abordagens implementadas no VisPipeline-MultiNetwork. Na baseada em redes, os valores apresentados nos diagramas são de redes individuais originais. Já na baseada em valores, os genes (identificadores dos vértices) apresentados no diagrama de Venn são os genes presentes na rede final.

Um fator importante para a comparação de redes é permitir que um número razoável delas sejam comparadas. Portanto, considerou-se também a utilização de diagramas Edwards-Venn, para permitir que até seis conjuntos possam ser comparados.

\footnotetext{
${ }^{3}$ Técnica de exploração de conjuntos por meio de diagramas de Venn interativos descrita na seção 3.1

${ }^{4} \mathrm{O}$ pipeline de visualização completo foi apresentado na Figura 30 e a janela de interação do componente MultiNetwork View Frame foi apresentada na Figura 35.

${ }^{5}$ Rede final é a rede formada pelo componente MultiNetwork Operations, como descrito na subseção 3.2.1 e indicado nas Figuras 30 e 33. Ela é derivada de operações de conjuntos sobre os vértices das redes e também sobre os atributos desses vértices.
} 
Não se considerou mais conjuntos pela alta complexidade dos diagramas. Além disso, a técnica InteractiVenn também foi implementada no VisPipeline-MultiNetwork, com menos funcionalidades do que a interface construída para o InteractiVenn website.

Na janela de exibição e interação (ver Figura 40) dos diagramas de Venn, o usuário pode: exibir os valores de uma determinada intersecção clicando sobre o valor numérico correspondente no diagrama; efetuar operações de união de conjuntos sobre o diagrama por meio de uma codificação simples escrita no campo Union code; voltar ao diagrama original desfazendo a operação de união realizada por meio do botão Reset diagram and sets; exportar o diagrama no formato SVG por meio do botão Export diagram (SVG); modificar os nomes dos conjuntos por meio do botão Change sets' names; exportar os conjuntos visíveis no momento, isto é, os que correspondem aos números apresentados no diagrama, por meio do botão Export visible sets (.csv).

Figura 40 - Janela de exibição e interação de diagramas de Venn do VisPipelineMultiNetwork.

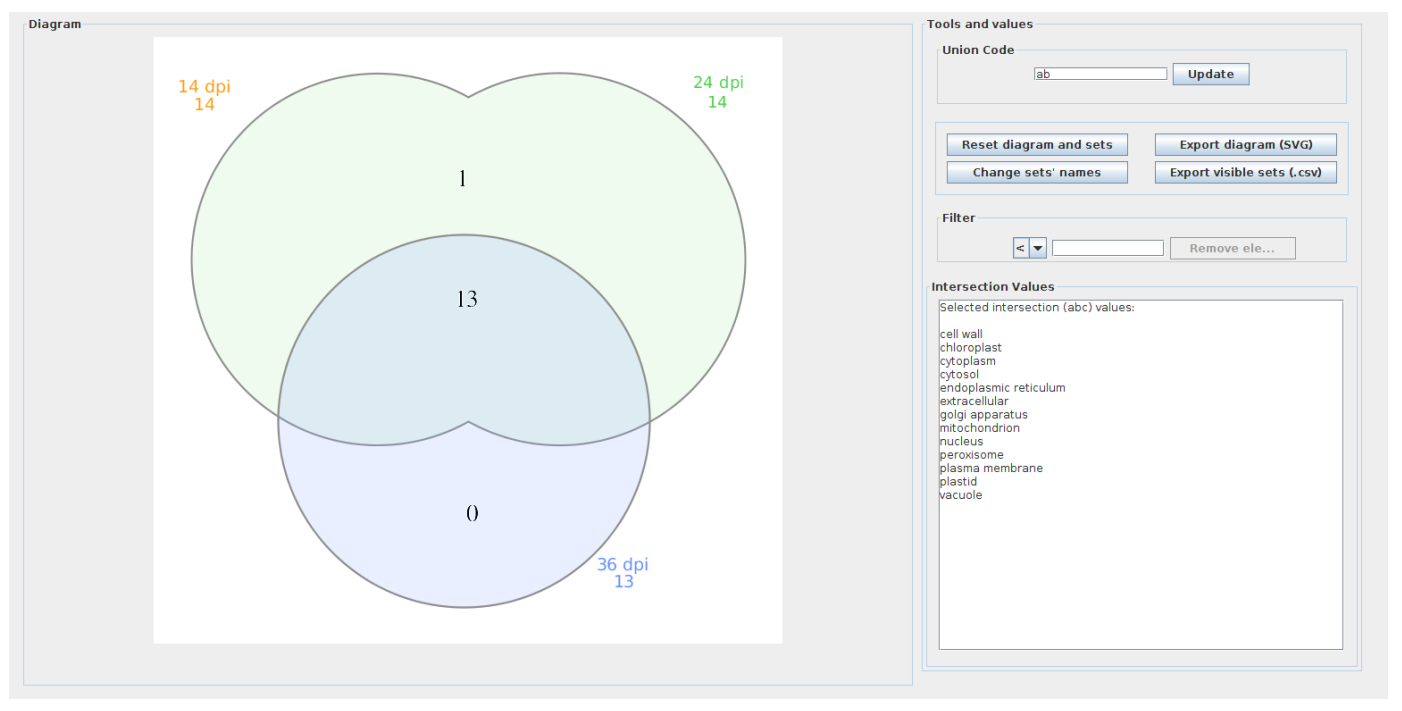

A codificação de operações de união funciona da seguinte maneira: a concatenação de identificadores dos conjuntos representa a união entre eles. Para efetuar mais de uma operação de união sobre, por exemplo, pares de conjuntos distintos, basta utilizar uma vírgula como separador. Por exemplo, a codificação da união entre $A$ e $B$ e entre $C$ e $D$ é $a b, c d$.

A criação dos diagramas depende dos vértices da rede final que estão selecionados na janela de visualização. Apenas vértices selecionados são considerados na construção do diagrama. Dessa forma, o usuário pode criar diagramas mais específicos, que consideram apenas os nós selecionados e o conteúdo contido neles. Por exemplo, para criar um diagrama que distribui em cada rede original (conjunto no diagrama de Venn) os processos biológicos que ocorrem no núcleo, basta selecionar os vértices que possuem o valor "núcleo" no atributo "partição celular" e criar um diagrama baseado no atributo "processo biológico". 
Muitos outros diagramas podem ser feitos a partir das mesmas redes por meio das operações de conjuntos sobre as redes, sobre os atributos, e também a partir da seleção dos vértices que participarão da construção do diagrama.

Para ilustrar a utilização do VisPipeline-MultiNetwork e da técnica InteractiVenn, foram realizados dois casos de análise no contexto biomolecular. Ambos são descritos no Capítulo 4. 



\section{Exemplos de Análise}

As redes biológicas são representadas por estruturas complexas e específicas, devido aos seus atributos serem textuais, categóricos, numéricos e, ainda, poderem ser vistos como atributos multivalorados. Para a análise desse tipo de dado o VisPipeline-MultiNetwork foi construído de forma a permitir análises que outras ferramentas para análise biológica não permitem.

Este capítulo contextualiza a utilização e a importância das técnicas desenvolvidas neste trabalho, exemplificando duas análises no contexto biomolecular. Tais análises servem apenas como exemplificação de como a ferramenta pode ser utilizada, já que o método utilizado foi de exploração inicial para entendimento dos dados.

Ambas as análises foram feitas com a colaboração de biólogos do LNBio. Os dados da primeira análise são de autoria daquele laboratório. A segunda análise utiliza dados publicados por outros autores e adaptados pelos colaboradores do LNBio para representarem redes.

Na primeira análise, apresentada na seção 4.1, os dados representam proteínas identificadas em amostras que passaram por um equipamento de cromatografia líquida acoplada a um espectrômetro de massa durante períodos de tempo variados. O objetivo foi comparar o que acontece com a identificação de proteínas se a amostra fosse deixada neste equipamento por mais ou menos tempo.

Na segunda análise, apresentada na seção 4.2, três redes que representam uma planta modelo são comparadas, a fim de se analisar suas diferenças e semelhanças com relação à regulação da transcrição dos genes correspondentes e também com relação aos processos biológicos associados. Cada rede representa um estágio de evolução de uma mesma doença nessa planta. Cada estágio é identificado pelo número de dias que se passaram após o início da infecção. Com isso, a comparação permite identificar quais proteínas ou processos deixaram de ser ativados ou começaram a ser importantes para a planta. Por exemplo, algumas vias metabólicas são ativadas pelo sistema de defesa da planta apenas quando há infecção. Dessa forma, essa via deve aparecer numa rede que representa uma planta infectada e não aparecer numa rede que representa uma planta saudável.

As análises são detalhadas em sequência nas seções a seguir. Cada seção inicia contextualizando o problema e continua mostrando a utilização do VisPipeline-MultiNetwork para analisar os dados. No primeiro caso, trata-se de um problema metodológico, no que diz respeito à análise de qual seria um tempo ideal de uso de um equipamento de espectrometria de massa. No segundo caso, o contexto é originalmente biomolecular. No entanto, utilizou-se uma abordagem para analisar os dados diferente daquela utilizada 
pelos autores dos dados originais. No trabalho original, os autores não utilizaram redes de proteínas para a comparação dos estágios da doença. Mais detalhes são oferecidos em cada uma das seções.

\subsection{Exemplo 1: Avaliação do proteoma de célula $\mathrm{HEK}^{1}$ em diferen- tes tempos de corrida no espectrômetro de massa}

Nesta seção, foram comparados os resultados de um espectrômetro para um tipo de célula em diferentes tempos de corrida. Para isso foi utilizado uma cultura de células humanas e o resultado do espectrômetro foi o conjunto de proteínas que este conseguiu identificar, deixando-as nele por diferentes período de tempo. Essa análise permite que sejam comparados os tempos de corrida, a fim de identificar qual é a diferença entre separar os peptídeos na cromatografia líquida por tempos que variam de 12 a 173 minutos. Ao todo, cinco tempos foram comparados.

\subsubsection{Motivação, definição do problema e design experimental}

No LNBio, e em outros laboratórios, a demanda por utilização do espectrômetro de massa é muito grande. Há, de maneira geral, uma fila de espera para sua utilização. Espectrômetros de massa foram utilizados por aproximadamente 5 mil horas no LNBio no ano de 2013. Mais estatísticas quanto ao uso estão disponíveis no website do laboratório: $<$ http://lnbio.cnpem.br/massspectrometry/main/history/>.

A alta demanda do equipamento foi motivação para a elaboração desta análise. Pretendeu-se avaliar os resultados do espectrômetro quando corridas amostras de um tipo de célula muito utilizada em pesquisas gerais em diferentes durações de tempo. As células utilizadas foram do tipo HEK 293 (HEK293) ATCC ${ }^{\circledR}$ CRL-1573 ${ }^{\mathrm{TM}}$ (Human Embryonic Kidney 293 cells) (ATCC, s.d.). Os tempos de utilização escolhidos são os tempos comuns de utilização do equipamento em pesquisas diversas.

As culturas HEK servem como modelo de células normais (não-cancerosas), são de fácil cultivo e são utilizadas há muitos anos em pesquisas de biologia celular. De modo geral, as amostras de cada condição de tempo desse exemplo são formadas por milhares de células.

Em um equipamento de cromatografia líquida acoplado ao espectrômetro de massa, o pesquisador pode deixar suas amostras por um tempo escolhido por ele mesmo ou de acordo com o tempo disponível do equipamento para utilização. Assim, um pesquisador poderia deixar suas amostras no equipamento por 12 minutos, correndo o risco de ser pouco

\footnotetext{
${ }^{1} \mathrm{~A}$ descrição desse tipo de célula está na subseção 4.1.1.
} 
4.1. Exemplo 1: Avaliação do proteoma de célula HEK em diferentes tempos de corrida no espectrômetro de massa

tempo, ou deixar 173 minutos, correndo o risco de estar ocupando tempo de máquina que não precisaria ser ocupado, mas disponibilizado para outros.

Neste experimento, mediu-se o quanto de informação o espectrômetro consegue identificar em 12, 30, 40, 120 e 173 minutos. Cada condição teve como resultado espectros que servem para identificar as proteínas que passaram pelo equipamento dentro de um determinado tempo.

A partir desses conjuntos de proteínas, redes foram construídas utilizando-se a plataforma IIS (CARAZZOLLE et al., 2014), a partir de um banco global de interações. Nas redes, foram trazidas também informações da base de dados Gene Ontology (ASHBURNER et al., 2000), como os processos biológicos associados e as partições celulares, dentre outras. Com isso, foram obtidos não apenas conjuntos de proteínas, mas redes que possuem mais informações sobre elas.

O objetivo desta análise é comparar as semelhanças e diferenças de abundância de proteínas e processos biológicos em cada condição, para comparar a eficiência do espectrômetro de acordo com o tempo de corrida escolhido.

Para isso, as redes associadas às condições foram carregadas no VisPipelineMultiNetwork. A principal funcionalidade do sistema utilizada para compará-las foi a de geração de diagramas de Venn e de representação visual e interação das redes.

Para que fosse possível obter conclusões gerais sobre a espectrometria de massa, seriam necessários testes com mais tipos de células e também, que fossem feitas replicatas desses experimentos. As conclusões obtidas, portanto, servem como motivação para a elaboração de hipóteses e de experimentos mais elaborados. Na subseção seguinte é descrita a utilização do VisPipeline-MultiNetwork para a análise dos experimentos realizados.

\subsubsection{Análise visual das cinco condições: 12, 30, 40, 120 e 173 minutos}

Dadas as cinco redes referentes às condições de 12, 30, 40, 120 e 173 minutos, um primeiro passo foi efetuar a união entre elas e visualizar a projeção da rede final. Para isso, utilizou-se o atributo Networks e o atributo referente aos processos biológicos, obtendo-se o resultado exibido na Figura 41. Nela, verifica-se que há no centro várias proteínas que aparecem em mais de uma condição e que nas bordas há as proteínas exclusivas de cada condição. Isso pode ser percebido pela representação visual dos múltiplos valores em forma de círculos divididos.

Outra maneira de se ter ideia de como as proteínas estão distribuídas entre as condições é por meio de um diagrama de Venn. Para isso, construiu-se um diagrama pelo atributo identificador (Gene) das proteínas (ver Figura 42). A principal diferença é que nesta visão o usuário tem um desenho geral que exibe informação numérica sobre os tamanhos das intersecções. Outra diferença é que o usuário não pode solicitar que as 
Figura 41 - Projeção baseada em processos biológicos e identificação de cada proteína em cinco condições diferentes. As cores indicam em quais condições as proteínas foram identificadas. Algumas foram identificadas em apenas uma condição, outras em duas, três, quatro ou cinco condições. Percebeu-se que há muitas proteínas em comum entre condições, no entanto, há também proteínas que foram identificadas em uma condição que não foram identificadas em outra, independentemente do tempo em que as amostras foram submetidas ao espectrômetro.

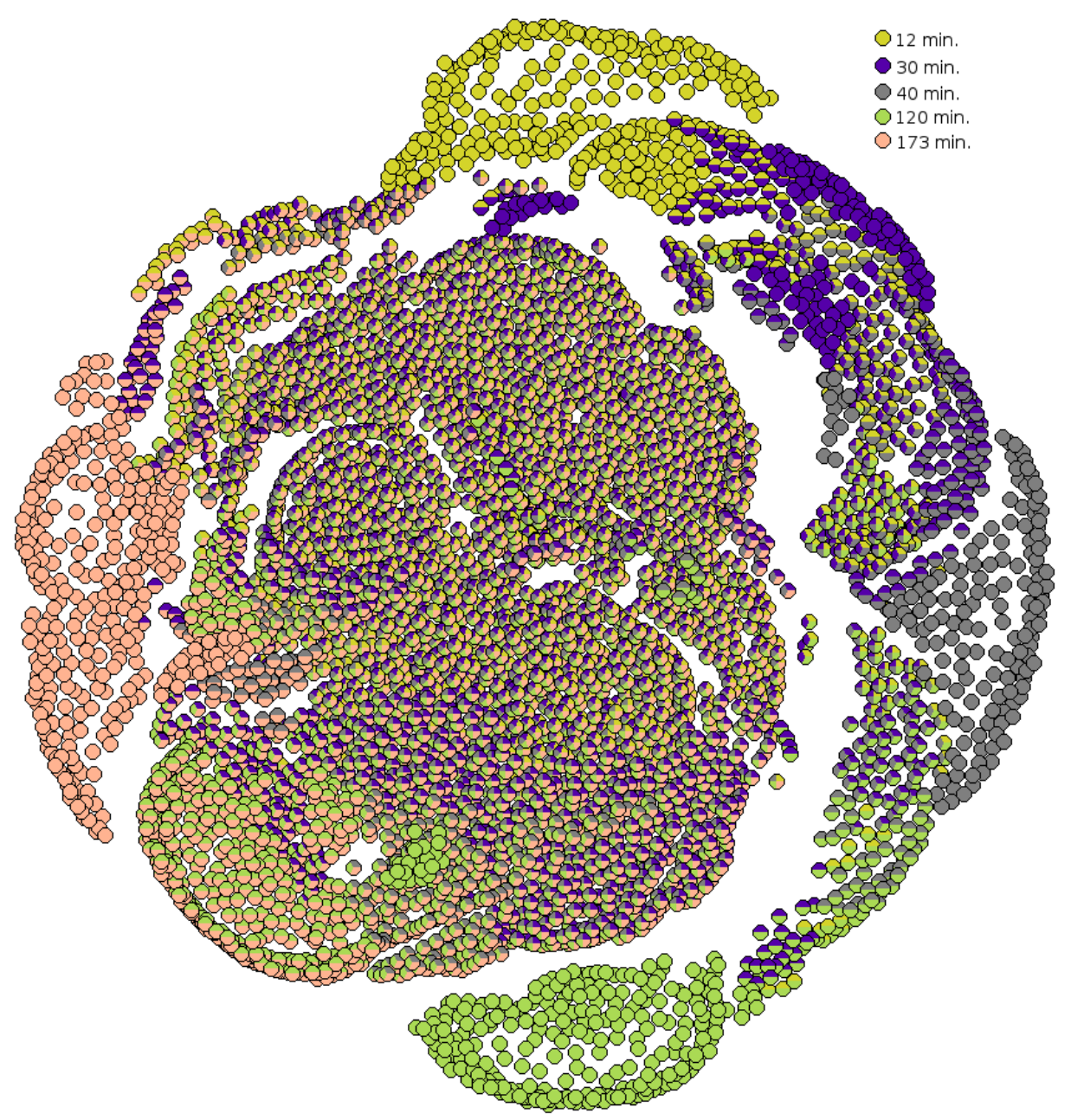

conexões entre proteínas sejam exibidas. No entanto, ele pode verificar quais proteínas estão em determinada intersecção, clicando no número que a representa no diagrama de Venn.

Cada região do diagrama expressa o número de proteínas que estão em determinadas condições e não estão em outras. É possível verificar quais e quantas proteínas apareceram em todas as condições. Por exemplo, é possível identificar quais e quantas apareceram apenas nas condições de 12 e 30 minutos (68) ou apenas nas condições de 120 e 173 minutos (420), quais aparecem em apenas uma das condições, entre outras situações.

Com o diagrama formado, pode-se fazer união entre conjuntos com a técnica InteractiVenn, a fim de se obter informações sobre outras intersecções, ou sobre os próprios 
Figura 42 - Diagrama representando as intersecções entre as cinco condições. Pode-se perceber que há 1723 proteínas em comum entre todas as condições e que há condições que chegam a ter até 308 proteínas exclusivas.

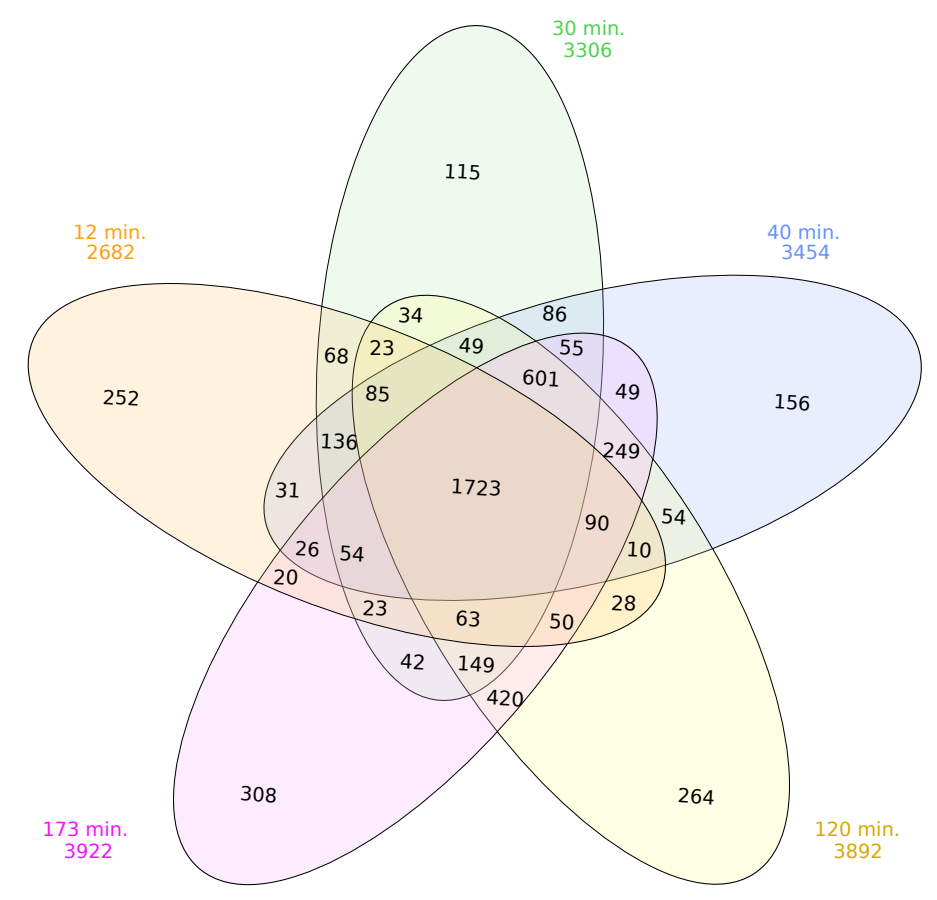

conjuntos. Se, por exemplo, se deseja comparar a condição de 40 minutos com a de 120 minutos e com a de 173 minutos, pode-se aplicar a união entre 12, 30 e 173 minutos e, em outro diagrama, a união entre 12, 30 e 120 minutos, respectivamente. Os resultados de tais operações podem ser vistos na Figura 43.

Ao somar as regiões de 120 minutos que não estão nas de 40 minutos, e fazer o mesmo para as regiões de 173 minutos, tem-se alguns totais que os diferenciam da condição de 40 minutos. A condição de 120 minutos possui 1031 proteínas que não estão na condição de 40 minutos. Já esta possui 593 proteínas que não estão na de 120 minutos. Quando a condição de 173 minutos é comparada com a de 40, os números passam a ser 1075 e 607, respectivamente.

Com essas contagens, percebeu-se que tanto o conjunto de 120 minutos como o de 173 minutos se diferenciam de forma similar do conjunto de 40 minutos, em número de proteínas, apesar da grande diferença entre os tempos.

Além do número de proteínas, é importante analisar como os processos biológicos estão distribuídos nas condições. Esses processos caracterizam as atividades que ocorrem na célula. Para isso, foi aplicado um filtro sobre as redes baseando-se no atributo p-valor dos top-processos biológicos, a fim de eliminar proteínas cujo processo biológico mais provável tem p-valor maior ou igual a 0.05. Cada processo biológico para cada proteína possui um p-valor próprio, atribuído a partir de um cálculo de enriquecimento (CARAZZOLLE et al., 2014), dependente das proteínas que formam a rede do usuário e das proteínas que 
Figura 43 - Diagramas representando a comparação entre dois conjuntos escolhidos. Em 43(a), a comparação das condições de tempo 40 e 120 minutos; em 43(b), a comparação dos tempos 40 e 173 minutos. O usuário executa a união de três conjuntos para que possa comparar os dois conjuntos restantes. O layout do diagrama original é mantido e o usuário não precisa criar novos diagramas nem aprender os novos posicionamentos.

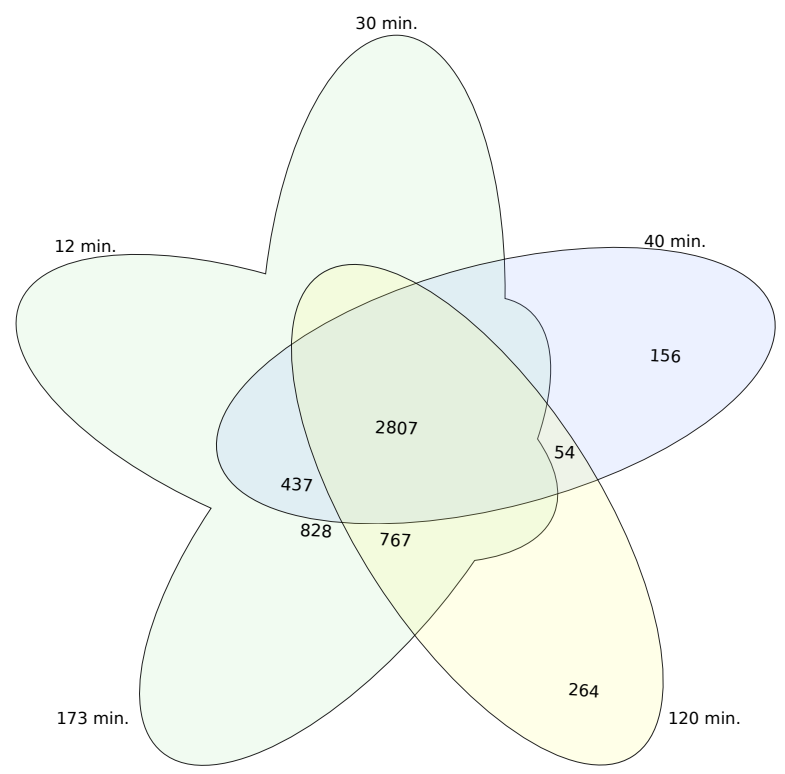

(a) 40 min. vs. 120 min.

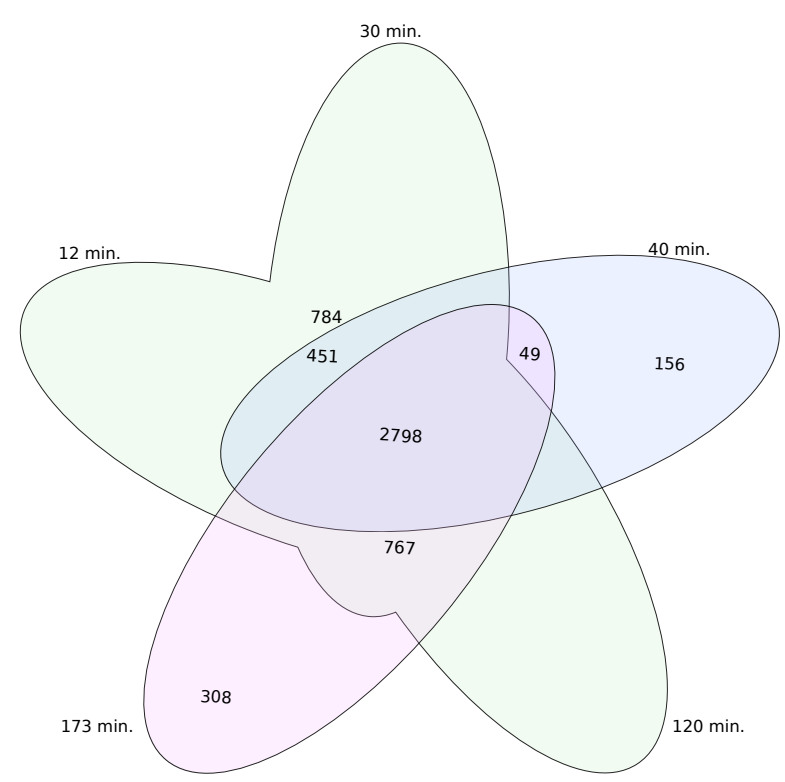

(b) 40 min. vs. 173 min.

formam a rede completa armazenada em bases de dados tal como o Gene Ontology.

Esse filtro elimina proteínas cujo processo biológico associado é incerto (p-valor maior ou igual a 0.05). Isso é feito porque, apesar de uma determinada proteína poder participar de um processo biológico no ser humano, naquela condição específica de estudo, ela estará participando com maior probabilidade de um processo mais enriquecido (com 
menor p-valor).

As bases de dados geralmente armazenam todas as interações e funções possíveis do ser vivo e calcula esse p-valor de acordo com as proteínas encontradas pelo usuário. Dessa forma, é como se o usuário especificasse para a base qual o tipo de célula com que ele está trabalhando. Porém, isso é feito indiretamente por meio de probabilidades.

O top-processo biológico é o processo mais provável daquela proteína participar, dada a rede na qual ela está inserida. Sendo assim, para cada rede, a proteína pode ter um top-processo diferente. Assim, fez-se um diagrama baseado no atributo top-processo biológico, para ver se há também um aumento significativo de processos com o aumento de proteínas identificadas.

Pela Figura 44 percebeu-se que as regiões exclusivas das condições deste diagrama têm certa relação com as regiões do diagrama da Figura 42. No entanto, se forem verificados os totais de processos biológicos encontrados em cada condição, não se pode afirmar que quanto maior for o tempo, mais processos biológicos serão encontrados, dado que com 173 minutos foram encontrados menos processos do que com 120 minutos.

Figura 44 - Diagrama de Venn comparando os processos biológicos encontrados nas cinco condições.

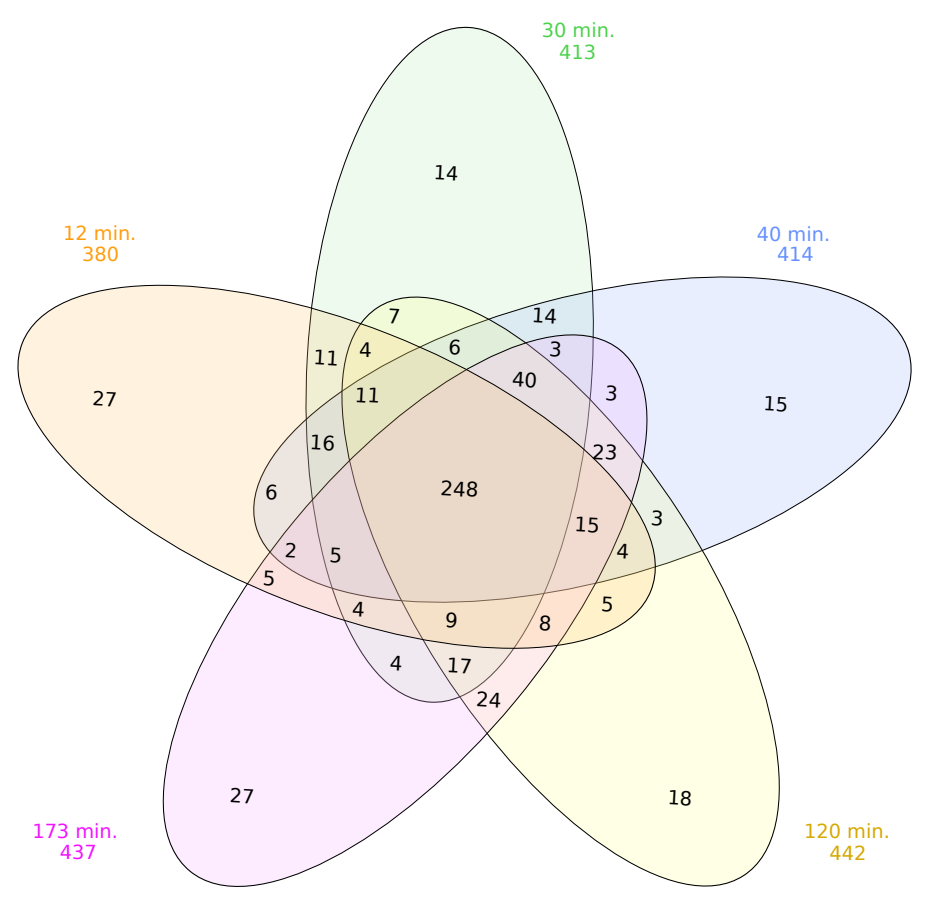

Essa variação para menos pode acontecer pela natureza do processo de identificação de proteínas por meio da espectrometria de massa. É interessante executar essa análise considerando replicatas, pois, mesmo fazendo dois experimentos com 120 minutos cada, pode-se obter conjuntos de proteínas ligeiramente diferentes.

Entre as cinco condições, a de 120 minutos parece ser um bom custo benefício. Em 
120 minutos, foram encontradas a mais que nos tempos 12, 30 e 40 minutos, respectivamente: 1210, 586 e 438 proteínas e 62, 29 e 28 processos biológicos. Foram encontradas apenas 30 proteínas a menos e 5 processos biológicos a mais que no tempo de 173 minutos. Pode-se dizer que nestes 53 minutos a mais, apenas 30 proteínas foram encontradas.

Considerando a razão entre as diferenças entre os conjuntos e os tempos entre as cinco condições, tem-se para 30-12, 40-30, 120-40 e 173-120 minutos as seguintes taxas de variação, respectivamente:

a) $34,66,14,8,5,475$ e 0,566 proteínas por minuto;

b) $1,77,0,10,0,35$ e $-0,09$ processos biológicos por minuto.

As diferenças totais das relações citadas acima são, respectivamente:

a) $624,148,438$ e 30 proteínas;

b) 33, 1, 30 e -5 processos biológicos.

As taxas de identificação de proteínas e processos por minuto totais, de cada uma das condições de 12, 30, 40, 120 e 173 minutos, são, respectivamente:

a) $223,5,110,2,86,35,32,43$ e 22, 67 proteínas por minuto;

b) $31,66,13,76,10,35,3,68$ e 2,52 processos biológicos por minuto.

Pelas análises, o tempo de 40 minutos é que resultou em uma boa fronteira de produtividade. Ele trouxe uma taxa de 10,35 processos biológicos por minuto e a partir daí essa taxa caiu ainda mais. Os tempos de 120 minutos e 173 minutos apresentaram taxas de 3,68 e 2,52 processos por minutos. Estes dois tempos são 3 e 4, 325 vezes maiores que 40 minutos, respectivamente, com um aumento apenas marginal de novas identificações.

Ao verificar as diferenças entre as condições de 40 minutos e 120 minutos, percebeuse que na segunda (120 minutos) foram encontradas apenas 438 proteínas e 30 processos biológicos a mais. Esses dois números correspondem a aproximadamente $12 \%$ e $7 \%$ da condição de 40 minutos e $11 \%$ e $6 \%$ da condição de 120 minutos. Na condição de 173 minutos, o número de processos biológicos é menor que na condição de 120 minutos e, ainda, há um aumento de apenas 30 proteínas, apesar dos 53 minutos de diferença entre essas condições. Quando são verificadas as diferenças entre 120 e 173 minutos, percebe-se que, com relação aos processos biológicos, não houve ganho nenhum; na verdade, houve perda. Quanto ao número de proteínas, obteve-se, aproximadamente, apenas $0.7 \%$ a mais no tempo de 173 minutos em relação ao de 120. Tais fatos evidenciam que 173 minutos é tempo demais e que 120 minutos são suficientes.

Quando o número de proteínas aumenta, o número de processos biológicos pode aumentar, diminuir ou permanecer o mesmo. Isso acontece porque muitas proteínas participam de um mesmo processo biológico. 
4.2. Exemplo 2: Alterações no transcritoma de Arabidopsis thaliana em resposta à infecção pelo vírus $S A C M V$

Sendo assim, é importante também definir qual das duas propriedades (número de proteínas ou número de processos biológicos) é realmente importante para o usuário do espectrômetro num experimento em particular. É evidente, pelos experimentos, que o número de proteínas aumenta com o aumento do tempo de corrida. Porém, a mesma relação não ocorre com o número de processos biológicos.

Tentou-se entender o comportamento dos resultados do espectrômetro de massa em relação ao tempo de corrida utilizado. Obteve-se indícios de que 40 ou 120 minutos podem ser o suficiente para se obter bons resultados do espectrômetro de massa para corridas feitas com amostras de células HEK. Utilizar 120 minutos são suficientes, mas 40 minutos já são produtivos para uma situação de disputa pelo equipamento.

Esse estudo serve como motivação para uma análise mais profunda do problema, com um design experimental mais elaborado. Este envolveria vários tipos de células e replicatas dos experimentos para reduzir o erro que o equipamento comete na identificação das proteínas.

\subsection{Exemplo 2: Alterações no transcritoma de Arabidopsis thaliana em resposta à infecção pelo vírus SACMV}

Nesta seção, três redes que representam uma planta (Arabidopsis thaliana) em um determinado estágio de infecção por vírus são comparadas. Para isso, foi utilizado o conjunto de dados de um artigo que trata dos níveis de transcrição dos genes, identificando quais estão altos e quais estão baixos em cada estágio da infecção. No entanto, o artigo não considera as redes de proteínas e identifica apenas vias metabólicas relacionadas. Neste trabalho de mestrado, utilizou-se uma abordagem diferenciada, em que os genes identificados serviram para carregar a respectiva rede de interações entre proteínas por meio da plataforma IIS (CARAZZOLLE et al., 2014). Dessa forma, o VisPipeline-MultiNetwork foi utilizado para demonstrar como as informações de transcrição podem ser analisadas sob uma perspectiva diferente, utilizando dados de proteínas e suas interações.

\subsubsection{Motivação, definição do problema e design experimental}

Arabidopsis thaliana é uma planta naturalmente encontrada na Europa, Ásia e América do Norte. Seu ciclo de vida dura aproximadamente seis semanas, incluindo a germinação, o aparecimento do talo principal, a floração e a maturação das primeiras sementes (MEINKE, 1998).

Recentemente, ela se tornou uma planta modelo, devido ao alto número de pesquisas envolvendo seu ciclo de vida e os produtos gerados a parir dela. Essa angiosperma simples pode ser usada para entender não apenas a própria espécie, mas outras espécies de plantas 
(MEINKE, 1998).

Não há um consenso de que essa planta deva ser o modelo utilizado. No entanto, os resultados obtidos até o momento a tornaram escolha de muitos pesquisadores. A ideia é que, quanto mais se sabe sobre uma espécie, mais se consegue entender os processos biológicos e se descobrir maneiras de alterá-los com sucesso (MEINKE, 1998).

Assim, se uma determinada espécie de feijão, por exemplo, estiver sofrendo por causa de um vírus e deixando lavouras improdutivas, pode-se partir de resultados obtidos pela planta modelo, partir do conhecimento já registrado e iniciar a pesquisa de como solucionar o novo problema.

Um exemplo de análise utilizando a Arabidopsis thaliana é o trabalho realizado por Pierce e Rey (2013), que analisou as mudanças globais no transcriptoma da planta associadas ao vírus South African cassava mosaic virus (SACMV), vírus que tem tornado plantações de mandioca improdutivas.

O SACMV se originou na África, onde há grande produção da mandioca; esta que por sua vez é a terceira principal fonte de carboidratos para humanos. Apesar do vírus não ter sido encontrado na América do Sul, mesmo com sua grande produção de mandioca, sabe-se que neste continente há vírus cujos sintomas são similares. Na África, segundo Fauquet e Fargette (1990), o vírus foi encontrado na década de 90 em muitas regiões, chegando a afetar mais de $80 \%$ das plantações, como é o caso de alguns distritos do Kenya (FAUQUET; FARGETTE, 1990; PATIL; FAUQUET, 2009).

A anotação do genoma da mandioca ainda está incompleto, isto é, há poucas informações agrupadas nas bases de dados e, consequentemente, é difícil tirar conclusões partindo-se de experimentos feitos com a própria planta. Por isso, Pierce e Rey (2013) estudaram a resistência da Arabidopsis thaliana (planta modelo) ao SACMV. A planta foi analisada durante 36 dias após a infecção, dividido o período em 3 estágios (condições). Uma planta adulta saudável foi infectada e utilizou-se suas folhas para a análise de transcriptoma nos períodos de 14, 24 e 36 dias pós-infecção (dpi) com o vírus.

Neste exemplo, foram utilizados os genes reportados em Pierce e Rey (2013) e analisados por meio de uma nova abordagem, baseada em redes de interação. Utilizou-se, para isso, anotações desses genes a partir de uma base de dados mais completa.

Os dados obtidos no trabalho de Pierce e Rey (2013) descrevem quais genes foram encontrados em cada condição e o nível de expressão de cada um. A partir desses genes, os autores buscaram as anotações relacionadas às vias metabólicas no banco de dados MIPS.

Neste trabalho de mestrado, os processos biológicos foram foco. Eles envolvem um número maior de subprocessos de metabolismo, sinalização e regulação, entre outros. Exemplos foram descritos na seção 2.1. 
4.2. Exemplo 2: Alterações no transcritoma de Arabidopsis thaliana em resposta à infecção pelo vírus $S A C M V$

As vias metabólicas são pequenas partes de algo maior; por exemplo, duas ou mais vias metabólicas podem juntas formar um processo biológico. As redes foram construídas por meio da plataforma IIS e as anotações com relação aos processos biológicos foram recuperadas da base Gene Ontology.

Os dados das três condições pós-infecção já são, na verdade, uma diferenciação de uma condição não infectada. Para isso, os autores do artigo utilizaram uma técnica chamada log2-fold-change, que subtrai os valores de expressão $\left(\mathrm{em} \log _{2}\right)$ das condições infectadas pelos valores da amostra controle. Descarta-se genes cujo valor de expressão em fold change entre - 2 e 2. Em outras palavras, utilizaram apenas genes cuja expressão é duas vezes menor ou duas vezes maior que a expressão da condição normal (controle).

Esse tipo de filtro reduz muito o número de proteínas encontradas nas condições pós-infecção. Além disso, quando esses genes foram buscados no banco de interações, muitos não possuíam interações entre si, por falta de informações registradas, dificultando o bom funcionamento do método.

Sendo assim, buscou-se também pelos vizinhos mais prováveis desses genes no interactoma da Arabidopsis thaliana, a fim de encontrar caminhos que unissem os genes "originais" que estavam desconexos (sem conexões diretas entre eles). Isso foi feito para que se pudesse ter mais informações sobre as prováveis vias que de fato acontecem na planta quando tais genes estão diferencialmente expressos em relação à condição normal. Essa etapa não precisaria ser feita se a base de interações fosse mais completa, como uma base de interações entre proteínas do interactoma humano. Note que as proteínas vizinhas não possuem informação de expressão, já que tal informação é obtida no próprio experimento e não na base de dados.

Esse conjunto de dados já transformado em redes foi examinado através do VisPipeline-MultiNetwork. As etapas de análise realizadas são descritas na subseção 4.2.2.

\subsubsection{Análise das três condições: 14, 24 e 36 dpi}

Com as três redes prontas, o pipeline de visualização descrito no Capítulo 3 é aplicado. Essencialmente quatro atributos foram foco da análise, sendo escolhidos para serem parâmetros para as técnicas, seja na etapa de projeção dos vértices, seja na etapa de criação de diagramas de Venn. São eles:

a) gene-name: identificador do nó, nome do gene que gera uma respectiva proteína no interactoma;

b) top-enriched-bp: o processo biológico (reparação de dna, transcrição, e outros) mais enriquecido para uma determinada proteína em uma determinada rede;

c) p-value (top-enriched-bp) $)^{2}$ : o p-valor ligado ao valor do atributo Top-enriched-

\footnotetext{
${ }^{2} \mathrm{O}$ p-valor de cada processo biológico é calculado pela ferramenta GO::TermFinder (BOYLE et al.,
} 
bp de uma proteína - quanto menor, mais enriquecido ele é naquela rede;

d) selected-cellular-component: a partição celular (núcleo, citoplasma, e outras) no geral, de maior ocorrência da proteína.

Esses atributos foram utilizados para descobrir informações de quantidades e identificações. Essas informações estão relacionada a:

a) genes up ou down regulados em cada condição;

b) processos biológicos enriquecidos em cada condição, com p-valor $<0,05$;

c) processos biológicos enriquecidos comuns entre as três condições, com p-valor $<$ 0,05

d) processos biológicos enriquecidos exclusivos de cada condições, com p-valor < 0,05 ;

e) genes up ou down regulados comuns entre as 3 condições;

f) genes up ou down regulados exclusivos de cada condição.

As projeções de redes finais também foram ilustradas nesta análise. Foram feitos os desenhos das seguintes redes:

a) rede obtida pela intersecção de genes entre as três condições, com posicionamento baseado em top-enriched-bp e selected-cellular-component;

b) rede obtida pelos genes exclusivos das três condições, com posicionamento baseado em top-enriched-bp e selected-cellular-component.

Entre as questões iniciais de análise, estavam as quantidades e identificações de proteínas com determinada característica em cada uma das redes, separadamente. Como o foco desta dissertação foi a comparação das redes, e não na análise individual, tal questão não pôde ser respondida pela ferramenta desenvolvida. Ela não aceita a entrada de apenas uma rede em sua versão atual, pois são necessárias de duas a seis redes para que o pipeline de comparação possa ser executado.

O Vispipeline-MultiNetwork, no entanto, foi capaz de identificar quais processos biológicos estão enriquecidos em cada condição por meio do diagrama de Venn. Criou-se um diagrama de Venn baseando-se no atributo top-enriched-bp com cada rede representando um conjunto. Este diagrama para os dados de Arabidopsis thaliana é exibido na Figura 45.

Nela, percebeu-se que a maioria dos processos biológicos se encontram nos dois primeiros estágios de contaminação. Isso pode ser verificado pelos números de processos exclusivos de cada uma (46 e 41); em oposição aos exclusivos da amostra de 36 dpi (14).

2004) por meio do cálculo de uma distribuição hipergeométrica entre o número de genes que existem na base de dados do GO $(N)$, o número de genes que possuem a anotação do processo biológico em questão $(r)$, o número de genes que existem no experimento $(n)$ e quantos destes possuem esse processo biológico anotado $(k)$. 
4.2. Exemplo 2: Alterações no transcritoma de Arabidopsis thaliana em resposta à infecção pelo vírus $S A C M V$

Figura 45 - Diagrama de Venn comparando os processos biológicos encontrados nas três condições.

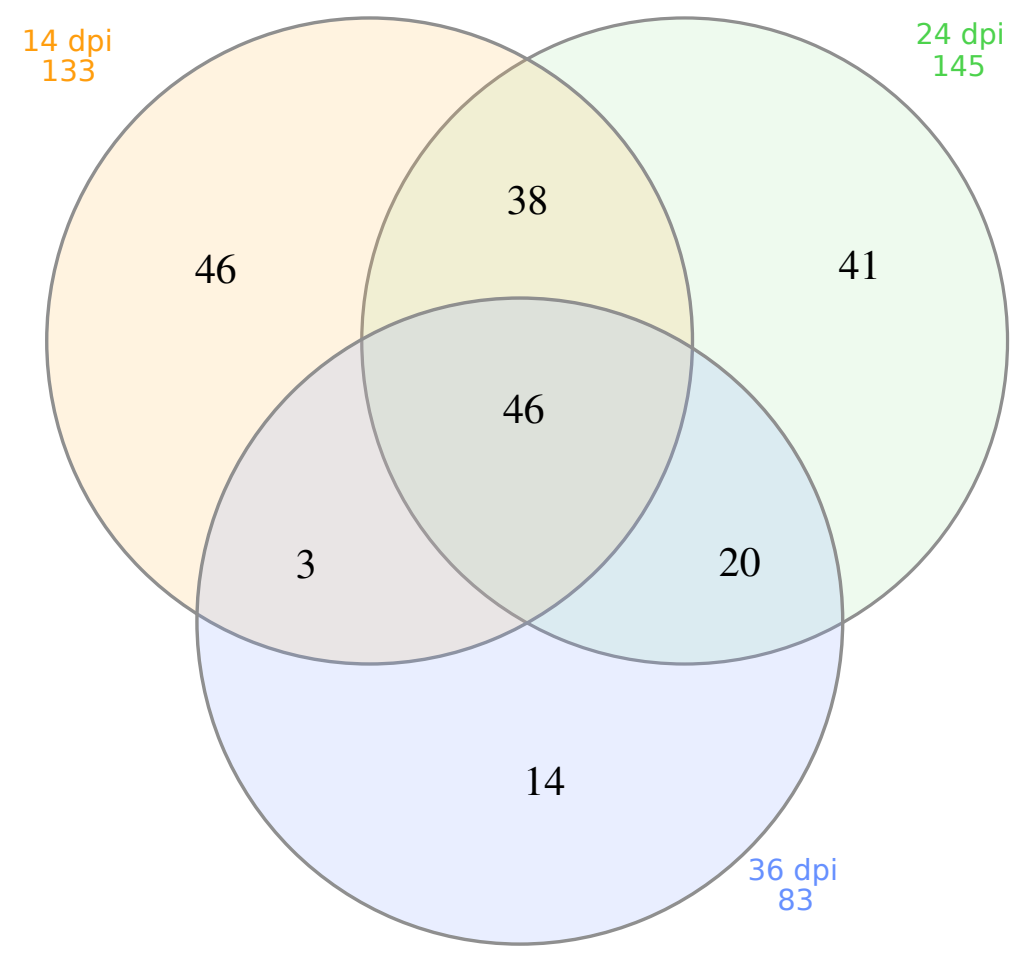

Percebeu-se também que apenas 46 (22\%) dos 208 processos biológicos enriquecidos foram encontrados em todas as condições. Para encontrar o número total de processos identificados, basta executar uma operação de união entre todos os conjuntos ou efetuar a soma dos três totais indicados no diagrama.

Esse número, além de ser pequeno, indicando mudanças fisiológicas drásticas, não indica que não houve alterações, no sentido de eles serem realmente executados ou não. A execução destes processos depende das proteínas relacionadas a eles estarem up reguladas nas três condições.

Para identificar os processos biológicos cujas proteínas se mantiveram up reguladas, ou seja, processos que realmente continuaram a ser executados ao longo da infecção, foi executada a intersecção entre as redes e a intersecção entre seus atributos. Dessa forma, apenas proteínas que apareceram em todas as condições fizeram parte da rede final e apenas valores que apareceram nas três condições foram mantidos nos vértices. Ou seja, um vértice terá o valor "up" armazenado apenas se ele teve esse valor nas três redes.

Dada a rede final, selecionou-se os vértices up-regulados para a construção do diagrama de Venn baseando-se nos atributos top-enriched-bp e, adicionalmente, no atributo biological-process, que informa todos os processos biológicos das quais a proteína pode participar (não necessariamente enriquecido nos dados em questão). Ambos os diagramas são exibidos na Figuras 46. 
Figura 46 - Diagramas de proteínas que estiveram up-reguladas em ambas as três condições. Em 46(a), é representado o atributo top-enriched-bp, enquanto em 46(b) é representado o biological-process.

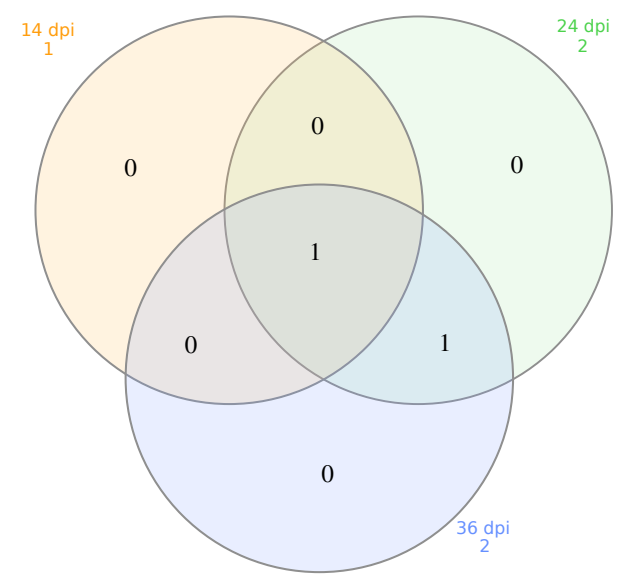

(a) top-enriched-bp

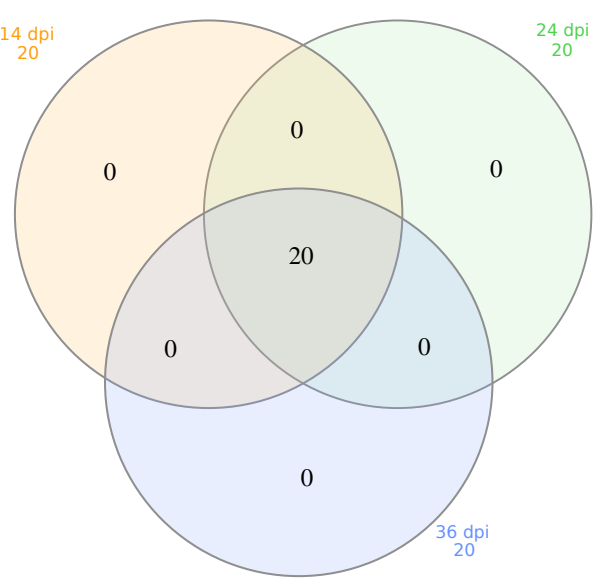

(b) biological-process

É importante se lembrar de que quando um diagrama de Venn é feito baseando-se em um atributo, a informação utilizada com relação aos valores dos atributos pertencem às redes originais. Dessa forma, para esse tipo de diagrama, a rede final e as operações de conjuntos feitas para gerar tal rede servem para o usuário visualizar a rede final ou executar seleções sobre ela. Os vértices selecionados na rede são como um filtro que define quais proteínas serão consideradas na recuperação da informação nas redes originais.

Com isso, obteve-se que o único processo biológico enriquecido que se manteve expresso nas três condições foi o response to auxin stimulus, visto na intersecção das três redes. Apesar deste processo ter sido mantido, uma proteína passou a participar de outro processo a partir de 24dpi. Esse valor pode ser visto na intersecção das condições de 24dpi e 36dpi: "transcription, dna-dependent".

Já quando são considerados todos os processos que poderiam ser desempenhados pelas proteínas selecionadas, foi encontrada uma lista contendo vinte processos distintos. Todos eles estão na intersecção entre as três condições, o que é previsível, pois não se está considerando seus níveis de enriquecimento (p-valor). Ou seja, uma proteína que aparece nas três condições tem para seu atributo biological-process todos os processos possíveis. É o enriquecimento dos processos biológicos em cada rede que dá o significado ao atributo top-enriched-bp.

Pode-se verificar ainda pela mesma rede quais são os genes up-regulados em comum às três condições por meio da visualização do desenho da rede, como é mostrado na Figura 47. No caso, foram encontrados os genes IAA29 e MBP1. Reexecutando o mesmo pipeline, mas agora considerando a intersecção de vértices e a união de atributos, foram encontrados outros genes que em algum momento estiveram up-regulados. As expressões encontradas por este pipeline estão listadas na Tabela 1. 
Figura 47 - Identificação de proteínas up-reguladas por meio do desenho da rede final formada pela intersecção entre vértices e entre atributos das três condições. As cores indicam o nível da regulação. É possível identificar proteínas cuja expressão não se alterou ao longo da infecção (vértices destacados na imagem) e quem são seus parceiros de interação. Foi utilizado o algoritmo baseado em forças para fazer o posicionamento dos vértices.

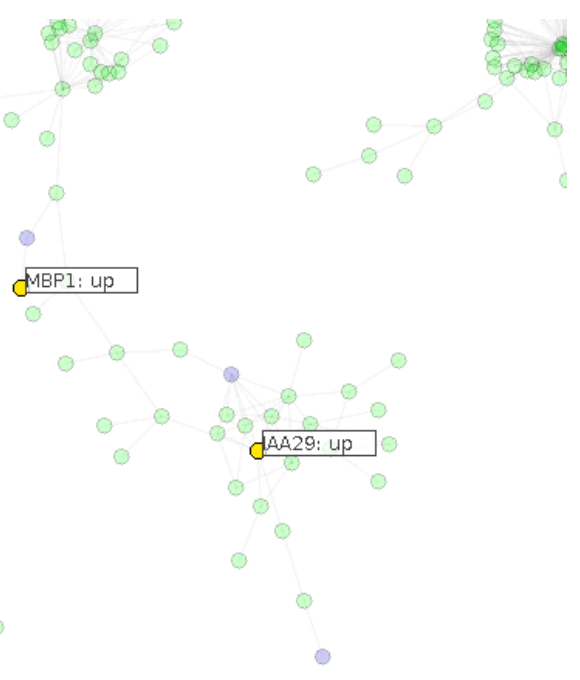

Tabela 1 - Tabela indicando genes e seus valores de expressão e a ausência de informação.

\begin{tabular}{cc}
\hline Gene & Expressão \\
\hline \hline TT8 & noinfo e down \\
KNAT1 & noinfo e down \\
KNAT7 & noinfo e down \\
ABI1 & noinfo e up \\
IAA5 & up, noinfo e down \\
IAA29 & up \\
MBP1 & up \\
\hline
\end{tabular}

Nota: O valor noinfo se refere à falta de informação sobre a expressão. Como foi feita a união entre os atributos das três condições, cada valor se refere a pelo menos uma condição.

Outra abordagem para obter esse tipo de informação é utilizar a projeção pelo atributo Networks, como o exemplo da Figura 36, para, então, selecionar os vértices de interesse. No caso da intersecção entre redes, basta selecionar os vértices que possuem três cores para construir o diagrama de Venn. A mesma ideia se aplica para encontrar propriedades exclusivas de cada rede, ou propriedades de combinações delas.

As proteínas down-reguladas também puderam ser analisadas por um processo similar à busca pelas up-reguladas. Não houve proteínas que apareceram nas três redes e que em todas estiveram down-reguladas. Então, repetiu-se o procedimento, porém, executando a união de atributos. Dessa maneira, pôde-se criar diagramas que exibem os processos biológicos e os processos biológicos mais enriquecidos das proteínas que 
pelo menos em alguma rede esteve down-regulada. Os diagramas podem ser vistos na Figura 48 da subseção 3.2.1.1. Neste caso, encontrou-se os processos cell fate specification e response to auxin stimulus relacionados apenas à primeira condição e os processos "negative regulation of transcription, dna-dependent", "transcription, dna-dependent" e "xylem and phloem pattern formation" relacionados às três condições.

Figura 48 - Diagramas de proteínas que aparecem em todas as redes e que estiveram down-reguladas em pelo menos uma delas. Em 48(a), é representado o atributo top-enriched-bp, enquanto em 48(b) é representado o biological-process.

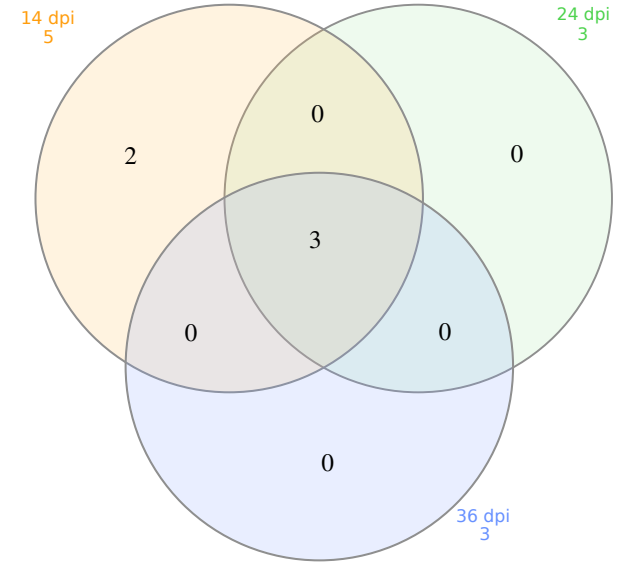

(a) top-enriched-bp

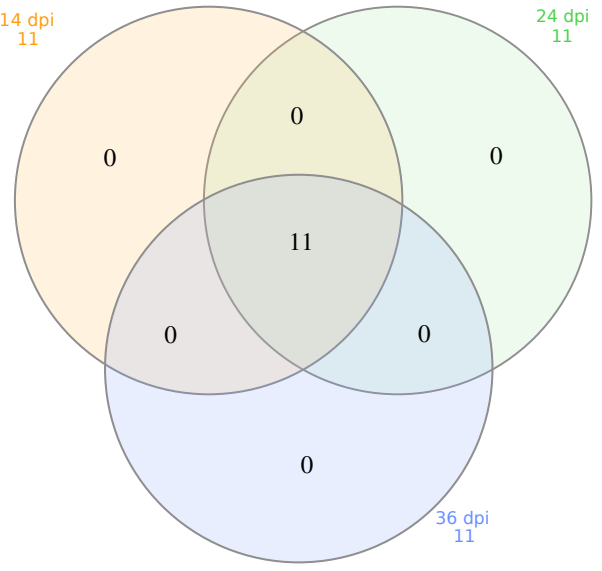

(b) biological-process

Para analisar exclusivos de uma rede usando a operação de exclusivos entre redes e entre atributos, o campo de busca pode ser utilizado. Por exemplo, pode-se buscar por "14" no atributo Networks para, então, construir um diagrama de Venn a partir dos vértices selecionados. A mesma ideia se aplica para as condições de 24 e 36 dpi. Dessa forma, constrói-se diagramas de Venn apenas com proteínas exclusivas de cada rede.

Ainda buscando pela expressão de cada gene, neste pipeline de exclusivos, utilizou-se o diagrama de Venn fazendo com que os valores up, down e noinfo fossem os conjuntos e os genes relacionados fossem seus elementos, para o atributo "expressão" (Venn baseado em valores). Com essa abordagem, os genes up e down-regulados exclusivos de cada condição foram identificados. Eles estão listados na Tabela 2.

Tabela 2 - Tabela relacionando genes e níveis de expressão de cada condição.

\begin{tabular}{cll}
\hline Condição & Genes up-regulados & Genes down-regulados \\
\hline \hline \multirow{2}{*}{14 dpi } & AT4G11890, AT4G20000, AT5G18010, & AFP1, AT1G07860, AT5G48650, EDL3, \\
& GRP3S, MYB113, SUC1, VSP1, WAK2, & ERF4, F3H, PAL1, PAL2, SKIP2, SYP21 e \\
& WRKY51 e XERICO & XT1 \\
24 dpi & AT3G13672, CDF3, GAI, GID1B, & ADT5, AT1G66760, AT5G53060, AT5G64850, \\
& MES9, OFP5, PHOT2, PKS1 e & BCA4, CLV2, FLA2, HEMA1, MKK6, \\
& WRKY75 & MYB15, NPR3, PUB23, SCL13 e TAF4B \\
36 dpi & PIN3 & CRF3, KRP6, NIA1 e NIA2 \\
\hline
\end{tabular}


Ao todo, foram encontrados 29 genes down-regulados e 20 genes up-regulados nas regiões exclusivas. Sendo que nas condições de 14, 24 e 36 dpi foram encontrados respectivamente 11, 14 e 4 genes down-regulados e 10, 9 e 1 genes up-regulados. Na Figura 49 são exibidos os quatro diagramas utilizados para identificar tais informações.

Figura 49 - Diagramas baseados em valores de expressão (up, down e noinfo) para os nós exclusivos das três condições. Os elementos dos conjuntos são os genes que têm tais valores associados na rede. Em (a), todas as condições foram selecionadas. Em (b), (c) e (d), as condições de 14, 24 e 36 dpi, respectivamente, foram selecionadas individualmente.

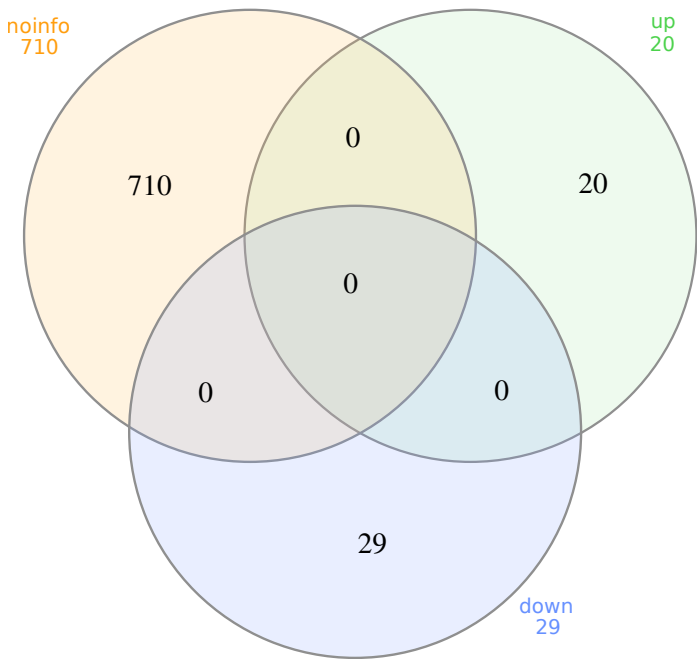

(a) 14,24 e $36 \mathrm{dpi}$

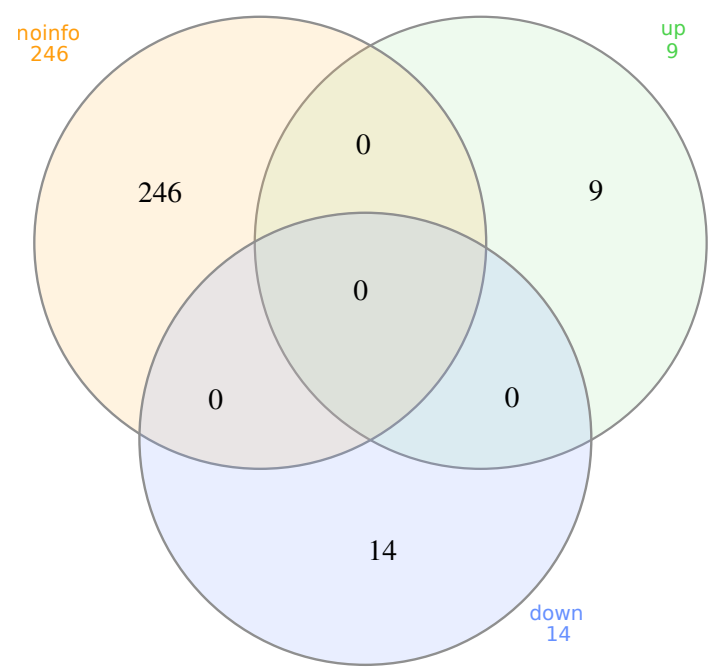

(c) $24 \mathrm{dpi}$

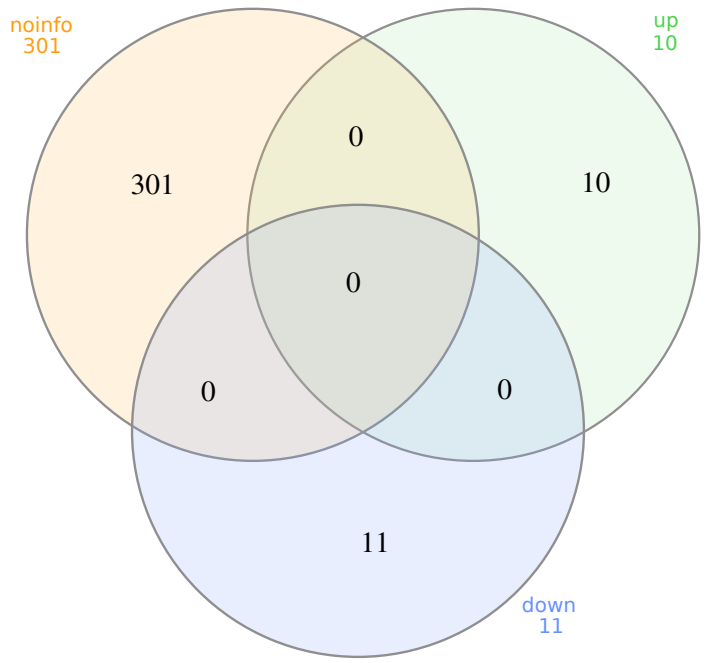

(b) $14 \mathrm{dpi}$

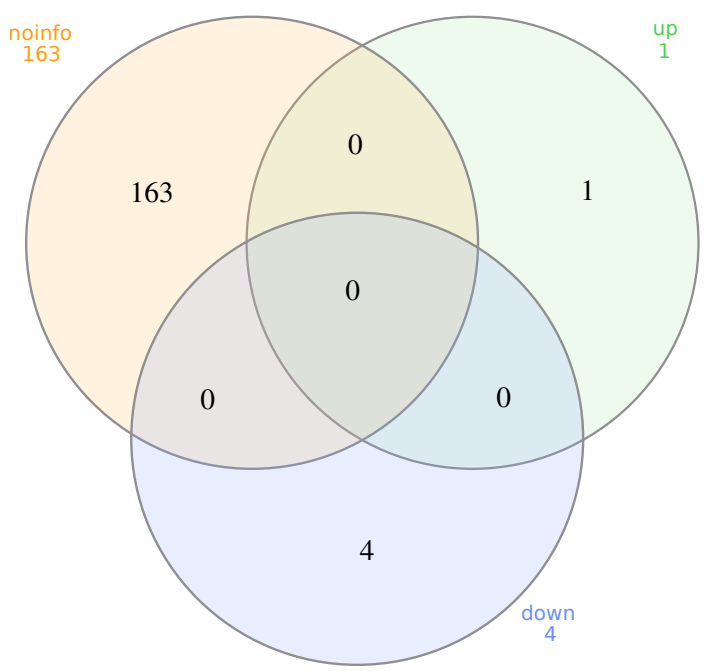

(d) 36 dpi

Ao se fazer a união por vértices e atributos das três redes e projetar a rede final baseando-se nos atributos Networks e top-enriched-bp obteve-se o resultado exibido na Figura 50 .

Além do usuário ter um referencial (polígono) informando em qual rede uma proteína foi encontrada, ele consegue localizar os processos biológicos pelas cores e identificar quais 
foram as proteínas cujo processo enriquecido se alterou entre uma condição e outra pelos vértices com mais de uma cor.

Outro exemplo é exibido na Figura 51. Nele, os atributos "expressão" e selectedcellular-component foram utilizados para projetar no plano. Destacou-se as partições celulares por meio de polígonos e identificou-se a expressão da proteína pela cor dos vértices.

Figura 50 - Projeção baseada nos atributos Networks e top-enriched-bp. Os polígonos destacam cada uma das três redes que foram unidas para formar os dados completos. As cores dos vértices indicam os valores do atributo multivalorado top-enriched-bp. Esse atributo armazena os processos biológicos da qual cada proteína pode participar com alta probabilidade. Como houve a união entre atributos e entre vértices das redes, esse atributo passou a ser multivalorado. Nas redes originais, esse atributo contém apenas o processo mais significativo em cada proteína.

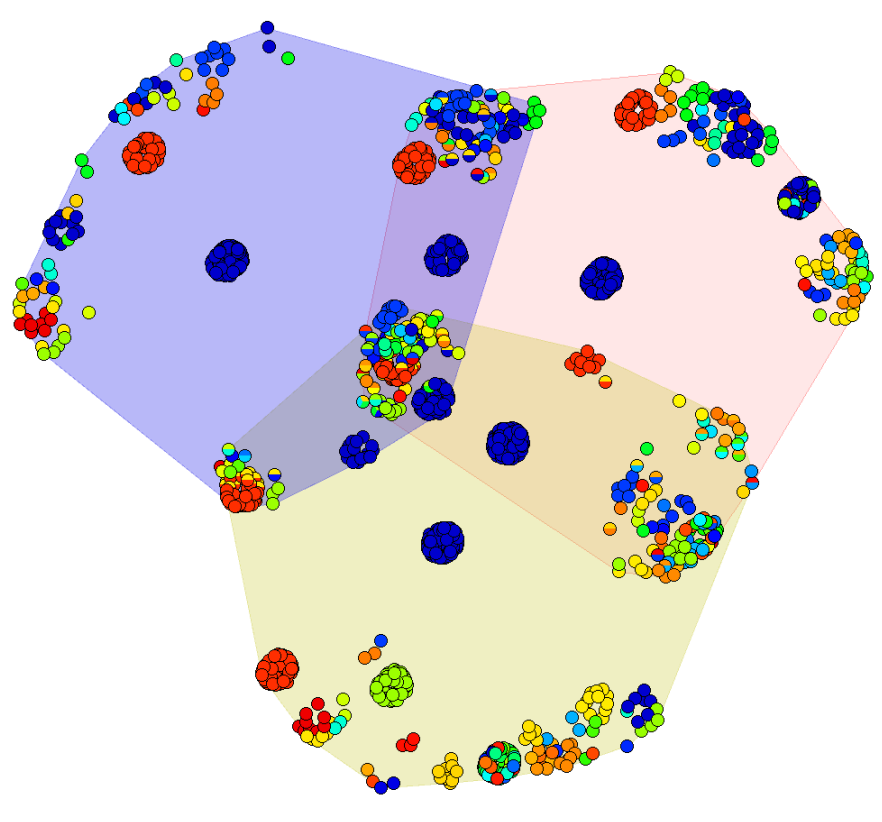

No pipeline anterior, observou-se que não parecia haver arestas entre vértices cujo nível de expressão é conhecido. Para comprovar, decidiu-se projetar as redes baseandose apenas no atributo de expressão dos genes e aplicar uma pequena perturbação pelo algoritmo baseado em forças. Percebeu-se que, na verdade, apenas dois pares de proteínas up-reguladas são parceiras de interação. Não há interação entre down-regulados, nem entre down e up-regulados. Tal fato já era esperado, dadas as dificuldades iniciais em encontrar interações entre as proteínas originais, sem considerar as vizinhas obtidas pela plataforma IIS. A seleção dos nós também facilitou a visualização, como visto na Figura 52.

É possível fazer diversas outras combinações entre operações entre vértices das redes, entre atributos, maneiras de desenhar o grafo, de colorí-lo, e a criação de diagramas de Venn, para explorar os dados e ter motivação para hipóteses biológicas. Um último exemplo é exibido na Figura 53. Trata-se da rede final da intersecção entre as três condições, 
Figura 51 - Projeção baseada nos atributos "expressão" e selected-cellular-component. Os polígonos destacam cada uma das partições celulares. As cores dos vértices indicam o nível de expressão dos nós. Nós em amarelo são up-regulados, nós em azul são down-regulados e nós em verde não possuem informação.

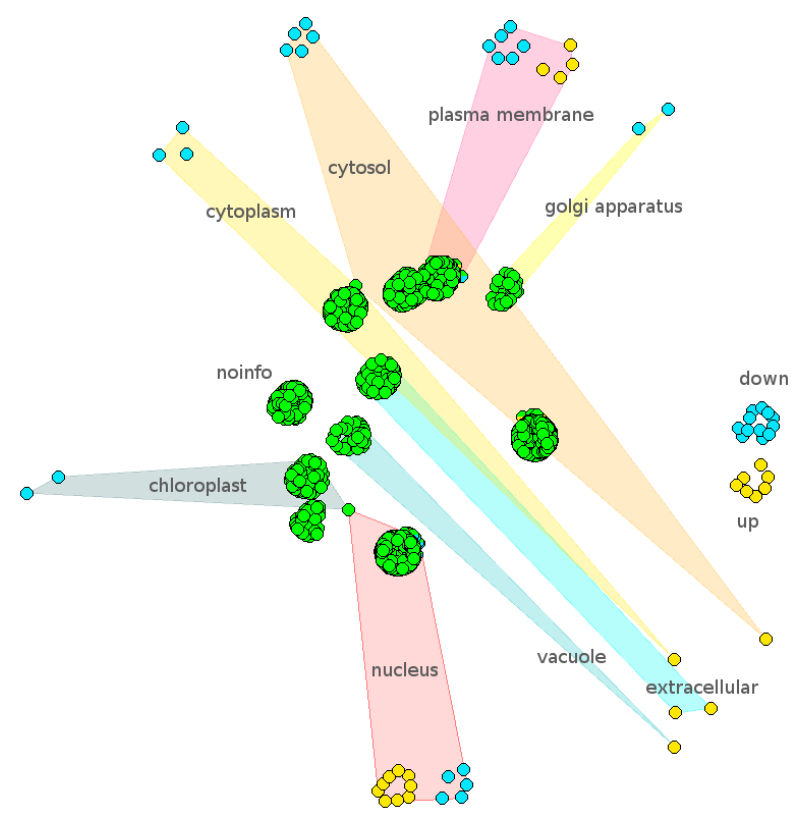

Figura 52 - Projeção baseada nos atributos "expressão". As cores dos vértices indicam o nível de expressão dos nós. Nós em amarelo são up-regulados, nós em azul são down-regulados e nós em verde não possuem informação. Nos nós azuis e amarelos foram selecionados para que as interações entre eles mesmos fossem destacadas. Apenas duas interações foram descobertas: a entre os genes PKS1 e PHOT2, e a entre os genes GAI e GID1B.

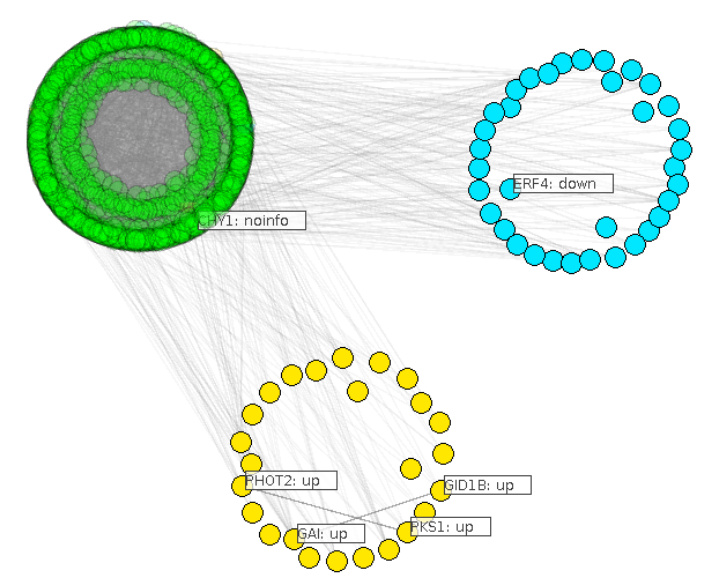

sendo que para os atributos foi realizada a união. O algoritmo de posicionamento baseado em forças foi utilizado para que se possa entender a topologia da rede.

Percebe-se que a intersecção possui parte dos vértices com grau zero (sem conexões) e os que não são se dividem em três componentes (pequenos grafos com conexões, separados uns dos outros). Apenas os vértices MBP1, ABI1, AA5, AA29 e KNAT7 possuem valor e se localizam no maior grupo formado. Os outros dois vértices com informação, que estão 
Tabela 1, não se conectam a nenhum outro vértice. Tal rede e propriedades servem de motivação para exploração de interações que ocorrem em todo o período de infecção.

Figura 53 - Rede indicando a interação e nível de expressão das proteínas que apareceram obrigatoriamente em todas as condições. O posicionamento dos vértices foi feito pelo algoritmo baseado em forças, a coloração indica o nível de expressão. Nós em amarelo são down-regulados, nós em azul são up-regulados e nós em cinza não possuem informação.

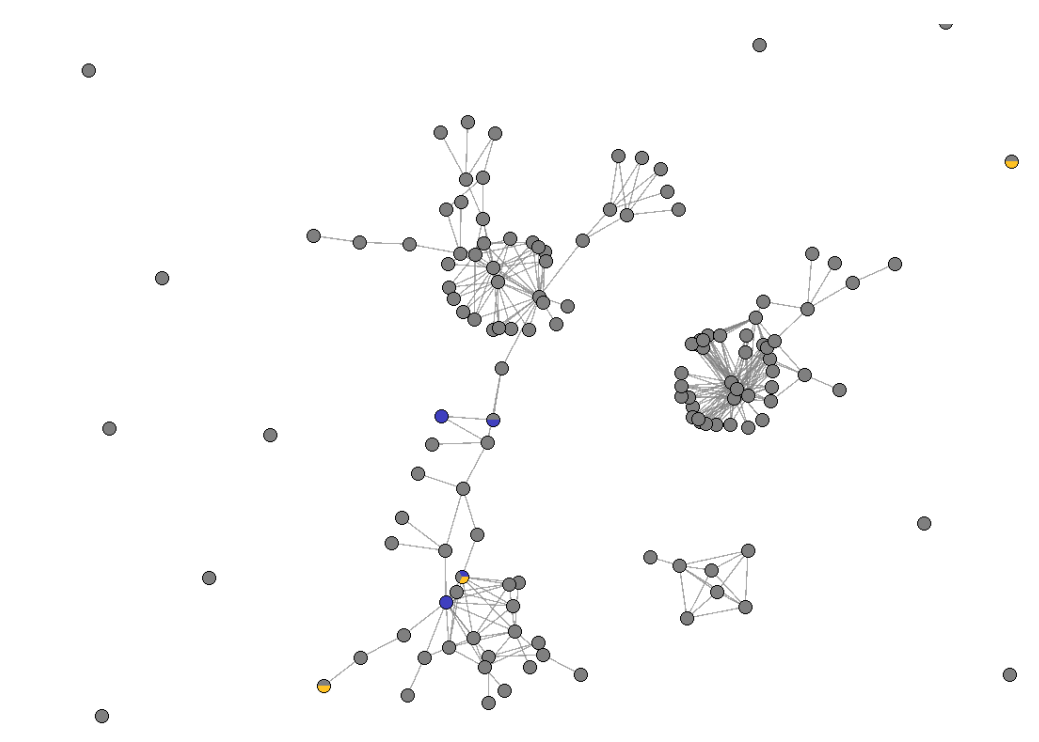

De modo geral, neste exemplo de análise, o VisPipeline-MultiNetwork permitiu que os dados de transcriptoma fossem analisados de maneira diferente da abordagem tradicional. O exemplo descrito aqui foi apenas uma demonstração de como um usuário poderia utilizar a ferramenta para realizar análises mais profundas, explorando os dados e confirmando hipóteses. No artigo original em que as três condições são comparadas, basicamente as informações utilizadas foram os genes de cada condição, seus níveis de expressão e as vias metabólicas relacionadas a eles. Já na abordagem utilizada neste trabalho de mestrado, com a utilização do VisPipeline-MultiNetwork, foi possível comparar as listas de genes entre condições diretamente na ferramenta por meio de diagramas de Venn. Além disso, outros diagramas de Venn puderam ser feitos para comparar também valores de atributos, como o que identifica se um um gene é up ou down-regulado. Informações diversas inseridas em atributos puderam ser analisadas por meio de interação com a ferramenta de visualização. Outro diferencial da abordagem utilizada foi a possibilidade de visualizar interações entre as proteínas. Com a busca pelas proteínas codificadas pelos genes em bases de interactomas, pôde-se obter um conjunto de dados com mais informações e essas informações puderam ser analisadas por meio do VisPipeline-MultiNetwork. No contexto dessa dissertação de mestrado, as análises realizadas não tiveram como objetivo descobrir informações biológicas, confirmar hipóteses biológicas ou propor soluções para tratar infecção pelo vírus SACMV. 


\section{Conclusões}

Neste trabalho de mestrado, foram construídas ferramentas de visualização cujo foco principal é a análise e comparação visual de redes biológicas. O software VisPipelineMultiNetwork implementa as ferramentas desenvolvidas. As redes processadas pelas ferramentas desenvolvidas contêm atributos nos nós, tais como localização, função biológica e quaisquer outras características de moléculas, além de informação de interações que podem ocorrer entre elas, representadas por arestas. A ferramenta demonstrou-se funcional para a exploração e comparação de redes desse tipo. Ela permitiu que fossem feitas análises que não poderiam ser feitas em ferramentas conhecidas, como o Gephi e o Cytoscape, por permitir operações sobre conjuntos de redes.

As novas ferramentas desenvolvidas neste trabalho foram exemplificadas com duas análises de situações reais. Na primeira, exemplificou-se da comparação visual de conjuntos de proteínas para o estudo do tempo mínimo ideal de análise de amostras de proteomas em um espectrômetro de massa. Esse estudo envolveu comparação dos conjuntos de proteínas expressos em tempos diferentes de exposição. Essa experimentação foi a etapa piloto de uma pesquisa que se pretende realizar com redes mais completas e com um design experimental mais e controlado.

Na segunda situação de teste, tentou-se aplicar uma abordagem diferente à análise de dados de transcriptoma. Esse problema incluiu dados de interactômica, com informações de interações biológicas em nível de processos biológicos e de interação entre proteínas. Essa abordagem também é uma tarefa inicial para que uma pesquisa posterior possa ser realizada, também mais elaborada e controlada. Ambas as situações foram motivação para a implementação das funcionalidades do VisPipeline-MultiNetwork, que se demonstrou muito útil para realizar as análises necessárias.

Com essas ferramentas, algumas tarefas podem ser feitas diretamente pelo usuário. Um exemplo é a construção de diagramas de Venn com base em características selecionadas como importantes. O usuário pode configurar o pipeline para que apareça ao final a informação que ele pretende visualizar. Quando várias combinações de conjuntos precisam ser feitas para concluir a análise, por exemplo, outras ferramentas obrigavam o usuário a combinar os conjuntos manualmente, separadamente das ferramentas de visualização e análise. No VisPipeline-MultiNetwork as operações de conjuntos sobre as redes originais para gerar uma rede fina permitem que o usuário possa criar vários tipos de filtros e combinações entre as redes e seus valores de atributos. Essa geração de redes combinadas, atreladas à abordagem InteractiVenn para exploração dos diagramas, permitem para criar muitas combinações de conjuntos e redes sem deixar o ambiente de visualização.

Com a necessidade de exploração de conjuntos de elementos, simples diagramas de Venn não são suficientes. O VisPipeline-MultiNetwork permite que sejam feitas operações 
de união, de intersecção e de identificação de vértices exclusivos entre as redes sob estudo. Além disso, gera diagramas de Venn com base apenas em vértices de interesse, a partir de seleção ou das operações entre redes. O usuário também pode explorar os valores dos atributos dos vértices pelos diagramas de Venn utilizando a técnica InteractiVenn. Outra funcionalidade adicionada à ferramenta foi a função Convex Hull, que permite a criação de polígonos a partir de vértices selecionados. Esses polígonos permitem que o usuário faça um mapeamento manual sobre a representação visual da rede final que ele criou, facilitando a memorização de informações e de como elas estão distribuídas no grafo. Para melhorar a correspondência entre o mapeamento visual e os subconjuntos baseados em atributos, é importante que o desenho da rede seja feito com base no conteúdo dos nós. Dessa forma, há dentro de um polígono uma maior concentração de vértices com os valores que aquele polígono está referenciando. A técnica de projeção IDMAP é utilizada para realizar tal tarefa. Com ela, vértices com atributos similares tendem a ficar próximos no plano.

Com a combinação de todos os elementos descritos nesta dissertação, é possível analisar dados biológicos e explorá-los, possibilitando que hipóteses sejam criadas e verificadas. Além disso, o VisPipeline-MultiNetwork aceita como entrada redes no formato XGMML, com apenas a modificação para atributos que são multivalorados originalmente. Além disso, a análise de diagramas de Venn e de redes com atributos de vértices é realizada em diversas áreas. Portanto, essa ferramenta tem potencial para ser aplicada a outros domínios.

A principal limitação do VisPipeline-MultiNetwork está relacionada à estrutura de dados. A análise de grandes redes biológicas (com mais de mil vértices), é um desafio para a área de Visualização de Informação, pelas limitações da visão humana e também pelas limitações computacionais relacionadas ao tempo de processamento. No caso de redes ainda maiores, como as de 10 mil vértices, fica muito difícil visualizar tanto as redes originais quanto a sua combinação. Essas redes, além de terem muitas moléculas representadas, têm ainda um número muito maior de interações representadas em arestas. O VisPipelineMultiNetwork não foi otimizado para a visualização de grandes redes biológicas. O número de vértices que a ferramenta é capaz de computar depende da velocidade do processador e da quantidade de memória RAM disponível. Em um computador pessoal com um processador de $3 \mathrm{Ghz}$ e 6 GB separados para a aplicação, 3 mil vértices foram carregados com facilidade pelo sistema. O algoritmo de posicionamento baseado em similaridades foi executado rapidamente com os exemplos analisados. No entanto, o algoritmo baseado em forças da ferramenta demorou para atingir um posicionamento adequado. Esse aspecto do tamanho da rede sugere o desenvolvimento de uma abordagem parecida com estratégias de controle de escala em múltiplos níveis.

Apesar das limitações mencionadas, a ferramenta possui funcionalidades que per- 
mitem a generalização da rede por meio do agrupamento visual que é gerado pelo posicionamento baseado em similaridades e também pela generalização das redes e dos atributos em forma de diagramas de Venn. O principal problema com relação à visualização é a análise das arestas, que se sobrepõem e acabam formando um fundo colorido contrário à boa visualização. Esse tipo de problema pode ser amenizado se o usuário filtrar vértices de interesse. Uma função (Keep) está disponível, a qual mantém visíveis apenas vértices selecionados e suas respectivas arestas. 



\section{Referências}

ASHBURNER, M. et al. Gene ontology: tool for the unification of biology. Nature genetics, v. 25, n. 1, p. 25-29, maio 2000. ISSN 1061-4036. Disponível em: <http://www.pubmedcentral.nih.gov/articlerender.fcgi?artid=3037419\&tool= pmcentrez\&rendertype=abstract $>$. Citado 2 vezes nas páginas 18 e 71 .

ATCC. 293 [HEK-293] (ATCC $\left.{ }^{\circledR} C R L-1573^{T M}\right)$. s.d. Disponível em: <http: //www.atcc.org/products/all/CRL-1573.aspx\#documentation>. Acesso em: 20/05/2014. Citado na página 70.

BADER, G. D.; BETEL, D.; HOGUE, C. W. V. BIND: the Biomolecular Interaction Network Database. Nucleic Acids Research, v. 31, n. 1, p. 248-250, 2003. Disponível em: <http://nar.oxfordjournals.org/content/31/1/248.abstract>. Citado na página 17.

BARABÁSI, A.-L.; OLTVAI, Z. N. Network biology: understanding the cell's functional organization. Nature reviews. Genetics, v. 5, n. 2, p. 101-113, 2004. ISSN 1471-0056. Disponível em: <http://www.ncbi.nlm.nih.gov/pubmed/14735121>. Citado na página 22 .

BASTIAN, M. et al. Gephi: an open source software for exploring and manipulating networks. ICWSM, v. 8, p. 361-362, 2009. Citado na página 38.

BERGE, C. Graphs and Hypergraphs. Amsterdam, Netherlands: North-Holland Publishing Company, 1973. Citado na página 37.

BOYLE, E. I. et al. GO::TermFinder-open source software for accessing Gene Ontology information and finding significantly enriched Gene Ontology terms associated with a list of genes. Bioinformatics, Oxford, England, v. 20, n. 18, p. 3710-3715, dez. 2004. ISSN 1367-4803. Disponível em: <http://www.pubmedcentral.nih.gov/articlerender.fcgi?artid= 3037731\&tool $=$ pmcentrez\&rendertype $=$ abstract $>$. Citado na página 80.

BRANDSTÄDT, A.; LE, V. B.; SPINRAD, J. P. Graph Classes: A Survey. Philadelphia, PA, USA: Society for Industrial and Applied Mathematics, 1999. Citado na página 37.

BRASCH, S.; LINSEN, L.; FUELLEN, G. Visualization of Aligned Biological Networks: A Survey. In: 2007 International Conference on Cyberworlds (CW'07). IEEE, 2007. p. 49-53. ISBN 0-7695-3005-2. Disponível em: <http://ieeexplore.ieee.org/lpdocs/epic03/ wrapper.htm?arnumber $=4390900>$. Citado 2 vezes nas páginas 19 e 39 .

CARAZZOLLE, M. F. et al. IIS - Integrated Interactome System: A Web-Based Platform for the Annotation, Analysis and Visualization of Protein-MetaboliteGene-Drug Interactions by Integrating a Variety of Data Sources and Tools. PLoS ONE, Public Library of Science, v. 9, n. 6, p. e100385, 06 2014. Disponível em: $<$ http://dx.doi.org/10.1371\%2Fjournal.pone.0100385>. Citado 3 vezes nas páginas 71, 73 e 77 .

CARROLL, J.; RUSKEY, F.; WESTON, M. Which n-Venn Diagrams Can Be Drawn with Convex k-Gons? Discrete 85 Computational Geometry, Springer, New York, NY, USA, v. 37, n. 4, p. 619-628, 2007. ISSN 0179-5376. Disponível em: <http://dx.doi.org/10.1007/s00454-007-1311-1>. Citado 2 vezes nas páginas 32 e 34. 
CHANG, Y. et al. Bioinformatics analysis for genome design and synthetic biology. Conference, Emerging Information Technology 2005., IEEE, p. 103-104, 2005. Disponível em: <http://ieeexplore.ieee.org/lpdocs/epic03/wrapper.htm?arnumber $=1544358>$. Citado na página 26.

CHATR-ARYAMONTRI, A. et al. MINT: the Molecular INTeraction database. Nucleic Acids Research, v. 35, n. suppl 1, p. D572-D574, 2007. Disponível em: $<$ http://nar.oxfordjournals.org/content/35/suppl \_1/D572.abstract $>$. Citado na página 18 .

D'HONT, A. et al. The banana (Musa acuminata) genome and the evolution of monocotyledonous plants. Nature, v. 488, n. 7410, p. 213-217, ago. 2012. ISSN 1476-4687. Disponível em: <http://www.ncbi.nlm.nih.gov/pubmed/22801500>. Citado 4 vezes nas páginas 45, 46, 47 e 48.

EDWARDS, A. W. F. Seven-set Venn diagrams with rotational and polar symmetry. Combinatorics Probability and Computing, n. September 2000, 1998. Disponível em: $<$ http://journals.cambridge.org/production/action/cjoGetFulltext?fulltextid $=46556>$. Citado na página 34.

FAUQuet, C.; FARGeTte, D. African Cassava Mosaic Virus: Etiology, Epidemiology, and Control. Plant Disease, v. 74, n. 6, p. 404-411, 1990. Disponível em: <http://www.apsnet.org/publications/PlantDisease/BackIssues/Documents/ 1990Articles/PlantDisease74n06_404.PDF>. Citado na página 78.

FRANCESCHINI, A. et al. STRING v9.1: protein-protein interaction networks, with increased coverage and integration. Nucleic acids research, v. 41, n. Database issue, p. D808-D815, jan. 2013. ISSN 1362-4962. Disponível em: < http://www.pubmedcentral.nih. gov/articlerender.fcgi?artid $=3531103 \&$ tool $=$ pmcentrez\&rendertype=abstract $>$. Citado na página 17 .

GENTILE, F. et al. Direct imaging of DNA fibers: the visage of double helix. Nano Letters, p. 10-15, 2012. Disponível em: <http://pubs.acs.org/doi/abs/10.1021/nl3039162>. Citado na página 17 .

GRÜNBAUM, B. Venn Diagrams I. Geombinatorics, v. 1, n. 4, p. 5-12, 1992. Citado na página 32 .

HAMBURGER, P.; PIPPERT, R. E. Venn said it couldn't be done. Mathematics magazine, Mathematical Association of America, v. 73, n. 2, p. 105-110, 2000. Disponível em: < http: //www.jstor.org/discover/10.2307/2691081?uid=2\&uid=4\&sid=21104516983793>. Citado na página 32.

HARRINGTON, E. a. et al. pRB plays an essential role in cell cycle arrest induced by DNA damage. Proceedings of the National Academy of Sciences of the United States of America, v. 95, n. 20, p. 11945-11950, set. 1998. ISSN 0027-8424. Disponível em: <http://www.ncbi.nlm.nih.gov/pmc/articles/PMC21745/>. Citado na página 18.

HENRY, N.; FEKETE, J.-D. MatrixExplorer: a Dual-Representation System to Explore Social Networks. IEEE Transactions on Visualization and Computer Graphics, IEEE Computer Society, Los Alamitos, CA, USA, v. 12, p. 677-684, 2006. ISSN 1077-2626.

Disponível em: <http://ieeexplore.ieee.org/xpl/articleDetails.jsp?arnumber $=4015417>$. Citado na página 37. 
HENRY, N.; FEKETE, J.-D.; MCGUFFIN, M. J. NodeTrix: a Hybrid Visualization of Social Networks. IEEE Transactions on Visualization and Computer Graphics, IEEE Computer Society, Los Alamitos, CA, USA, v. 13, p. 1302-1309, 2007. ISSN 1077-2626. Disponível em: <http://ieeexplore.ieee.org/xpl/articleDetails.jsp?arnumber $=4376154>$. Citado na página 37.

JAIN, E. et al. Infrastructure for the life sciences: design and implementation of the UniProt website. BMC bioinformatics, v. 10, p. 136, jan. 2009. ISSN 1471-2105. Disponível em: < http://www.pubmedcentral.nih.gov/articlerender.fcgi?artid=2686714\&tool= pmcentrez\&rendertype=abstract $>$. Citado na página 18 .

JEONG, H. et al. The large-scale organization of metabolic networks. Nature, v. 407, n. 6804, p. 651-654, out. 2000. ISSN 0028-0836. Disponível em: < http: //www.ncbi.nlm.nih.gov/pubmed/11034217>. Citado na página 22.

KAMADA, T.; KAWAI, S. An algorithm for drawing general undirected graphs. Inf. Process. Lett., Elsevier North-Holland, Inc., Amsterdam, The Netherlands, The Netherlands, v. 31, n. 1, p. 7-15, 1989. ISSN 0020-0190. Disponível em: < http://www.sciencedirect.com/science/article/pii/0020019089901026>. Citado na página 39.

KESTLER, H. a. et al. Generalized Venn diagrams: a new method of visualizing complex genetic set relations. Bioinformatics, Oxford, England, v. 21, n. 8, p. 1592-1595, abr. 2005. ISSN 1367-4803. Disponível em: <http://bioinformatics.oxfordjournals.org/content/ 21/8/1592.long $>$. Citado 2 vezes nas páginas 35 e 36.

KHOLODENKO, B. N.; HANCOCK, J. F.; KOLCH, W. Signalling ballet in space and time. Nature reviews. Molecular cell biology, v. 11, n. 6, p. 414-426, jun. 2010. ISSN 1471-0080. Disponível em: <http://www.pubmedcentral.nih.gov/articlerender.fcgi?artid= 2977972\&tool=pmcentrez\&rendertype=abstract $>$. Citado na página 22.

LEE, T. I. et al. Transcriptional regulatory networks in Saccharomyces cerevisiae. Science, New York, NY, USA, v. 298, n. 5594, p. 799-804, out. 2002. ISSN 1095-9203. Disponível em: <http://www.ncbi.nlm.nih.gov/pubmed/12399584>. Citado na página 22.

LIU, T. et al. BindingDB: a web-accessible database of experimentally determined protein-ligand binding affinities. Nucleic Acids Research, v. 35, n. suppl 1, p. D198-201, 2007. ISSN 1362-4962. Disponível em: <http://nar.oxfordjournals.org/content/35/suppl 1/D198.full.pdf+html>. Citado na página 18.

LONGABAUGH, W. Combing the hairball with BioFabric: a new approach for visualization of large networks. BMC Bioinformatics, v. 13, n. 1, p. 275, 2012. ISSN 1471-2105. Disponível em: <http://www.biomedcentral.com/1471-2105/13/275>. Citado na página 38.

LOVASZ, L.; PELIKAN, J.; VESZTERGOMBI, K. Matemática Discreta. Rio de Janeiro: Sociedade Brasileira de Matemática, 2003. Citado na página 29.

MAMAKANI, K.; RUSKEY, F. A New Rose : The First Simple Symmetric 11-Venn Diagram. arXiv preprint arXiv:120\%.6452, 2012. Disponível em: <http: //arxiv.org/abs/1207.6452>. Nenhuma citação no texto. 
MARSHALL, R. J. Scaled rectangle diagrams can be used to visualize clinical and epidemiological data. Journal of Clinical Epidemiology, v. 58, n. 10, p. 974-981, 2005. ISSN 0895-4356. Disponível em: <http://www.jclinepi.com/article/S0895-4356\%2805\% 2900145-9/abstract $>$. Citado na página 35.

MARTINS, R. M. et al. Multidimensional Projections for Visual Analysis of Social Networks. Journal of Computer Science and Technology, Springer US, v. 27, n. 4, p. 791-810, 2012. ISSN 1000-9000. Disponível em: < http: //link.springer.com/article/10.1007\%2Fs11390-012-1265-5>. Citado 4 vezes nas páginas $39,55,60$ e 61 .

MEINKE, D. W. Arabidopsis thaliana: A Model Plant for Genome Analysis. Science, v. 282, n. 5389, p. 662-682, out. 1998. Disponível em: <http://www.sciencemag.org/cgi/doi/10. 1126/science.282.5389.662http://www.sciencemag.org/content/282/5389/662.abstract>. Citado 2 vezes nas páginas 77 e 78 .

MEWES, H. W. MIPS: a database for genomes and protein sequences. Nucleic Acids Research, v. 30, n. 1, p. 31-34, jan. 2002. ISSN 13624962. Disponível em: $<$ http://nar.oxfordjournals.org/lookup/doi/10.1093/nar/30.1.31>. Citado na página 18.

MILO, R. et al. Network motifs: simple building blocks of complex networks. Science, New York, NY, USA, v. 298, n. 5594, p. 824-827, out. 2002. ISSN 1095-9203. Disponível em: <http://www.ncbi.nlm.nih.gov/pubmed/12399590>. Citado na página 22.

MORAN, N. A.; JARVIK, T. Lateral transfer of genes from fungi underlies carotenoid production in aphids. Science, New York, NY, USA, v. 328, n. 5978, p. 624-627, abr. 2010. ISSN 1095-9203. Disponível em: <http://www.ncbi.nlm.nih.gov/pubmed/20431015>. Citado na página 23.

NAMATA, G. M. et al. A dual-view approach to interactive network visualization. In: Proceedings of the sixteenth ACM conference on Conference on information and knowledge management. New York, NY, USA: ACM, 2007. (CIKM '07), p. 939-942. ISBN 978-1-59593-803-9. Citado na página 37.

NETTO, P. O. B. Grafos: Teoria, Modelos, Algoritmos. São Paulo: Editora Edgard Blücher, 2003. Citado na página 36.

OLIVEROS, J. VENNY - An interactive tool for comparing lists with Venn Diagrams. 2007. Disponível em: <http://bioinfogp.cnb.csic.es/tools/venny/index.html>. Acesso em: 27/04/2014. Citado na página 43.

PATIL, B. L.; FAUQUET, C. M. Cassava mosaic geminiviruses: actual knowledge and perspectives. Molecular Plant Pathology, v. 10, p. 685-701, 2009. Disponível em: <http://dx.doi.org/10.1111/j.1364-3703.2009.00559.x>. Citado na página 78.

PELLEGRINI, M.; HAYNOR, D.; JOHNSON, J. M. Protein interaction networks. Expert review of proteomics, v. 1, n. 2, p. 239-249, ago. 2004. ISSN 1744-8387. Disponível em: $<$ http://www.ncbi.nlm.nih.gov/pubmed/15966818>. Citado na página 22.

PIERCE, E. J.; REY, M. E. C. Assessing Global Transcriptome Changes in Response to South African Cassava Mosaic Virus [ZA-99] Infection in Susceptible Arabidopsis thaliana. PloS one, v. 8, n. 6, p. e67534, jan. 2013. ISSN 1932-6203. Disponível 
em: <http://www.pubmedcentral.nih.gov/articlerender.fcgi?artid=3694866\&tool= pmcentrez\&rendertype=abstract $>$. Citado na página 78 .

PIMENTEL, M.; SANTOS-REBOUÇAS, C.; GALlO, C. Genética Essencial. 1. ed. Rio de Janeiro, RJ: Editora Guanabara Koogan LTDA, 2013. 296 p. ISBN 978-85-277-2189-9. Citado na página 26.

PIVETTA, M. Mais bits a serviço do DNA. Pesquisa Fapesp 204, p. 16-21, 2013. Citado na página 17.

PUNIN, J.; KRISHNAMOORTHY, M. XGMML (eXtensible Graph Markup and Modeling Language). 2001. Disponível em: <http://www.cs.rpi.edu/research/groups/pb/punin/ public_html/XGMML/>. Acesso em: 03/05/2014. Citado na página 55.

RADCLIFFE, N. J. Nested Venn Diagrams. 2010. Disponível em: <http: //stochasticsolutions.com/pdf/NestedVenn.pdf $>$. Acesso em: 10/04/2013. Citado 2 vezes nas páginas 32 e 35.

REDFIELD, R. Useful Genetics. University of British Columbia, 2013. Disponível em: $<$ https://class.coursera.org/usefulgenetics-001>. Acesso em: 07/07/2013. Citado na página 22.

ROMAN, S. Discrete Mathematics. Philadelphia, PA, USA: Harcourt College Publishers, 1989. Citado na página 29.

SAMATOVA, N. F. et al. An outlook into ultra-scale visualization of large-scale biological data. In: Ultrascale Visualization, 2008. UltraVis 2008. Workshop on. Austin, TX, USA: IEEE, 2008. p. 29-39. Citado na página 19.

SANDIFER, C. E. How Euler did it. [S.l.]: Mathematical Association of America, 2007. 256 p. Citado 2 vezes nas páginas 30 e 31.

SCHWENK, A. J. Venn diagram for five curves. Math. Magazine, v. 57, p. 297, 1984. Citado na página 32.

SEIDEL, C. Pangloss Venn diagram generator. s.d. Disponível em: < http: //www.pangloss.com/seidel/Protocols/venn4.cgi>. Acesso em: 27/04/2014. Citado na página 43.

SHANNON, P. et al. Cytoscape: a software environment for integrated models of biomolecular interaction networks. Genome research, Cold Spring Harbor Lab, v. 13, n. 11, p. 2498-2504, 2003. Disponível em: <http://genome.cshlp.org/content/13/11/2498.short>. Citado na página 38.

SHARAN, R.; IDEKER, T. Modeling cellular machinery through biological network comparison. Nature Biotechnology, v. 24, n. 4, p. 427-433, 2006. ISSN 1087-0156. Citado 2 vezes nas páginas 19 e 40.

SHEN, Z.; MA, K.-L.; ELIASSI-RAD, T. Visual Analysis of Large Heterogeneous Social Networks by Semantic and Structural Abstraction. IEEE Transactions on Visualization and Computer Graphics, IEEE Computer Society, Los Alamitos, CA, USA, v. 12, p. 1427-1439, 2006. ISSN 1077-2626. Citado na página 38. 
SMOOT, M. E. et al. Cytoscape 2.8: new features for data integration and network visualization. Bioinformatics, Oxford Univ Press, v. 27, n. 3, p. 431-432, 2011. Disponível em: <http://bioinformatics.oxfordjournals.org/content/27/3/431.short $>$. Citado na página 38.

STARK, C. et al. BioGRID: a general repository for interaction datasets.

Nucleic Acids Research, v. 34, n. suppl 1, p. D535-D539, 2006. Disponível em: <http://nar.oxfordjournals.org/content/34/suppl_1/D535.long > . Citado na página 18.

Virginia Commonwealth University. A New Frontier: Systems Biology. 2009. Disponível em: <https://www.youtube.com/watch?v=bnKhzRpXPvM>. Acesso em: 15/03/2014. Citado na página 21.

W3C. Scalable Vector Graphics (SVG) 1.0 Specification. 2001. Disponível em: <http://www.w3.org/TR/SVG10/>. Acesso em: 03/05/2014. Citado na página 48.

WATTS, D. J.; STROGATZ, S. H. Collective dynamics of 'small-world' networks. Nature, v. 393, n. 6684, p. 440-442, jun. 1998. ISSN 0028-0836. Disponível em: <http://www.ncbi.nlm.nih.gov/pubmed/9623998>. Citado na página 22.

WILES, A. M. et al. Building and analyzing protein interactome networks by cross-species comparisons. BMC systems biology, v. 4, p. 36, jan. 2010. ISSN 1752-0509. Disponível em: <http://www.pubmedcentral.nih.gov/articlerender.fcgi?artid=2859380\&tool= pmcentrez\&rendertype $=$ abstract $>$. Citado na página 22 .

XENARIOS, I. et al. DIP: the Database of Interacting Proteins. Nucleic Acids Research, v. 28, n. 1, p. 289-291, 2000. Disponível em: <http://nar.oxfordjournals.org/content/28/ 1/289.short $>$. Citado na página 17.

XIAO, C. et al. Top-k set similarity joins. In: Data Engineering, 2009. ICDE '09. IEEE 25th International Conference on. [S.l.: s.n.], 2009. p. 916-927. ISSN 1084-4627. Citado na página 59 . 